\title{
Albendazole for lymphatic filariasis (Review)
}

\author{
Addiss D, Gamble CL, Garner P, Gelband H, Ejere HOD, Critchley JA, International
} Filariasis Review Group

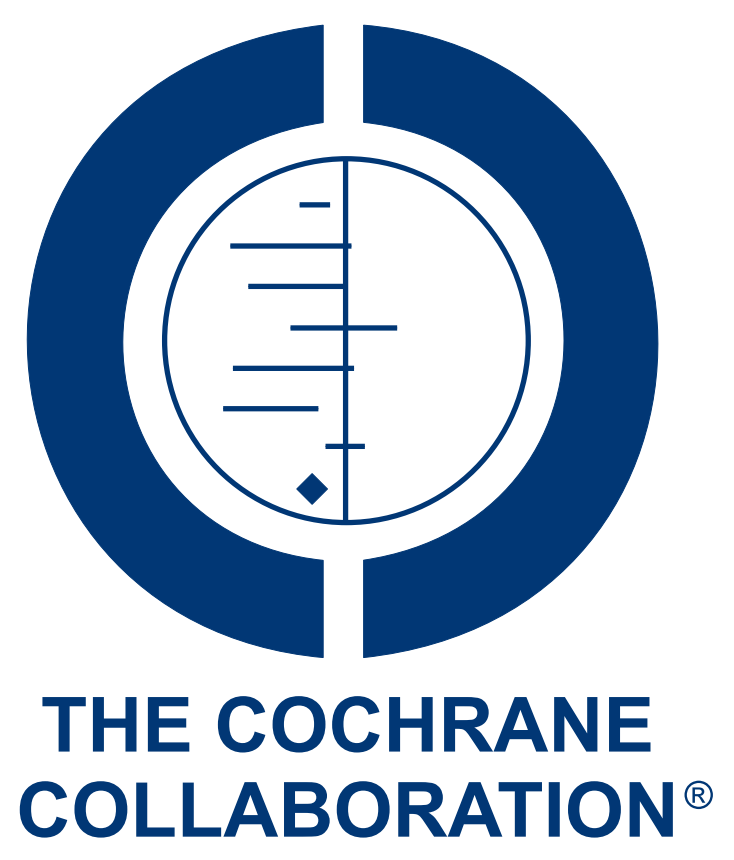

This is a reprint of a Cochrane review, prepared and maintained by The Cochrane Collaboration and published in The Cochrane Library 2009, Issue 1

http://www.thecochranelibrary.com

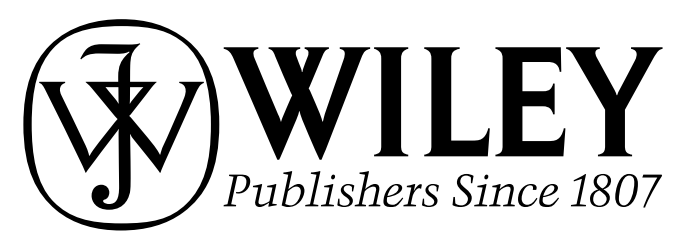

Albendazole for lymphatic filariasis (Review)

Copyright @ 2009 The Cochrane Collaboration. Published by John Wiley \& Sons, Ltd. 
TABLE OF CONTENTS

HEADER . . . . . . . . . . . . . . . . . . . . . . . . . . . . . . . . 1

ABSTRACT .. . . . . . . . . . . . . . . . . . . . . . . . . . . . . . . . . . . . . . . . . . . . . . . . .

PLAIN LANGUAGE SUMMARY . . . . . . . . . . . . . . . . . . . . . . . . . . . . . . . . . . . $\quad$. 2

BACKGROUND . . . . . . . . . . . . . . . . . . . . . . . . . . . . . . . . . . . . . 2

OBJECTIVES . . . . . . . . . . . . . . . . . . . . . . . . . . . . . . . . . . . . . . . . 4

METHODS . . . . . . . . . . . . . . . . . . . . . . . . . . . . . . . . . . . . . . 44

RESULTS . . . . . . . . . . . . . . . . . . . . . . . . . . . . . . . . . . . . . . . 6

DISCUSSION . . . . . . . . . . . . . . . . . . . . . . . . . . . . . . . . . . . . . $\quad .12$

AUTHORS' CONCLUSIONS . . . . . . . . . . . . . . . . . . . . . . . . . . . . . . . . . . . . . . .

ACKNOWLEDGEMENTS . . . . . . . . . . . . . . . . . . . . . . . . . . . . . . . . . . . . . . . . . 13

REFERENCES . . . . . . . . . . . . . . . . . . . . . . . . . . . . . . . . . . . . . . . 13

CHARACTERISTICS OF STUDIES . . . . . . . . . . . . . . . . . . . . . . . . . . . . . . . . . . . . . . 16

DATA AND ANALYSES . . . . . . . . . . . . . . . . . . . . . . . . . . . . . . . . . . . . . . . . . . . . . . . . . . 24

Analysis 1.1. Comparison 1 Albendazole versus placebo, Outcome 1 Microfilariae (mf) prevalence: all participants (both $\mathrm{mf}$ positive or negative at baseline). $\quad . \quad$. . . . . . . . . . . . . . . . . . . . . . . . . . . . . . . .

Analysis 1.2. Comparison 1 Albendazole versus placebo, Outcome 2 Microfilariae (mf) prevalence: only participants $\mathrm{mf}$ positive at baseline. . . . . . . . . . . . . . . . . . . . . . . . . . . . . . . . . . . . . . . . . .

Analysis 1.3. Comparison 1 Albendazole versus placebo, Outcome 3 Antigen prevalence: all participants (both mf positive or negative at baseline)..$\quad$. . . . . . . . . . . . . . . . . . . . . . . . . . . . . . . . . . 28

Analysis 1.4. Comparison 1 Albendazole versus placebo, Outcome 4 New clinical disease. . . . . . . . . . . . . . $\quad 29$

Analysis 1.5. Comparison 1 Albendazole versus placebo, Outcome 5 Pre-existing clinical disease. . . . . . . . . . . 29

Analysis 1.6. Comparison 1 Albendazole versus placebo, Outcome 6 Adverse events. . . . . . . . . . . . . . . . . . 30

Analysis 2.1. Comparison 2 Albendazole versus ivermectin, Outcome 1 Microfilariae (mf) prevalence: all participants (both $\mathrm{mf}$ positive or negative at baseline). . . . . . . . . . . . . . . . . . . . . . . . . . . 30

Analysis 2.2. Comparison 2 Albendazole versus ivermectin, Outcome 2 Microfilariae (mf) prevalence: only participants $\mathrm{mf}$ positive at baseline. . . . . . . . . . . . . . . . . . . . . . . . . . . . . . . . . 31

Analysis 2.3. Comparison 2 Albendazole versus ivermectin, Outcome 3 Antigen prevalence: all participants (antigen positive or negative at baseline). $\quad . \quad$. . . . . . . . . . . . . . . . . . . . . . . . . . . . . . . . . . . . . .

Analysis 2.4. Comparison 2 Albendazole versus ivermectin, Outcome 4 New clinical disease. . . . . . . . . . . . . . 32

Analysis 2.5. Comparison 2 Albendazole versus ivermectin, Outcome 5 Pre-existing clinical disease. . . . . . . . 32

Analysis 2.6. Comparison 2 Albendazole versus ivermectin, Outcome 6 Adverse events. . . . . . . . . . . . . . . . 33

Analysis 3.1. Comparison 3 Albendazole plus ivermectin versus ivermectin, Outcome 1 Microfilariae (mf) prevalence: all participants (both $\mathrm{mf}$ positive or negative at baseline). . . . . . . . . . . . . . . . . . . . . . . . . . . . 33

Analysis 3.2. Comparison 3 Albendazole plus ivermectin versus ivermectin, Outcome 2 Microfilariae (mf) prevalence: only participants $\mathrm{mf}$ positive at baseline.

Analysis 3.3. Comparison 3 Albendazole plus ivermectin versus ivermectin, Outcome 3 Antigen prevalence: all participants (antigen positive or negative) at baseline. . . . . . . . . . . . . . . . . . . . . . . . . .

Analysis 3.4. Comparison 3 Albendazole plus ivermectin versus ivermectin, Outcome 4 Antigen prevalence: only participants antigen positive at baseline. . . . . . . . . . . . . . . . . . . . . . . . . . 35

Analysis 3.5. Comparison 3 Albendazole plus ivermectin versus ivermectin, Outcome 5 New clinical disease. . . . $\quad 35$

Analysis 3.6. Comparison 3 Albendazole plus ivermectin versus ivermectin, Outcome 6 Pre-existing clinical disease. . 36

Analysis 3.7. Comparison 3 Albendazole plus ivermectin versus ivermectin, Outcome 7 Adverse events. . . . . . . 36

Analysis 4.1. Comparison 4 Albendazole versus diethylcarbamazine (DEC), Outcome 1 Microfiliariae (mf) prevalence: all participants (both $\mathrm{mf}$ positive or negative at baseline). . . . . . . . . . . . . . . . . . . . . 37

Analysis 4.2. Comparison 4 Albendazole versus diethylcarbamazine (DEC), Outcome 2 Microfilariae (mf) prevalence: only participants mf positive at baseline. . . . . . . . . . . . . . . . . . . . . . . . . . . . . . . 37

Analysis 4.3. Comparison 4 Albendazole versus diethylcarbamazine (DEC), Outcome 3 Antigen prevalence: all participants (both antigen positive or negative at baseline). . . . . . . . . . . . . . . . . . . . . . . . . . . . . . 38

Analysis 4.4. Comparison 4 Albendazole versus diethylcarbamazine (DEC), Outcome 4 Antigen prevalence: only participants antigen positive at baseline. . . . . . . . . . . . . . . . . . . . . . . . . . . . . . . 39

Analysis 4.5. Comparison 4 Albendazole versus diethylcarbamazine (DEC), Outcome 5 Adverse events. . . . . . . $\quad 39$

Albendazole for lymphatic filariasis (Review)

Copyright @ 2009 The Cochrane Collaboration. Published by John Wiley \& Sons, Ltd. 
Analysis 4.6. Comparison 4 Albendazole versus diethylcarbamazine (DEC), Outcome 6 Adverse events: scrotal syndrome.

Analysis 5.1. Comparison 5 Albendazole plus diethylcarbamazine (DEC) versus DEC, Outcome 1 Microfilariae (mf) prevalence: all participants (both $\mathrm{mf}$ positive or negative at baseline) . . . . . . . . . . . . . . . . . . .

Analysis 5.2. Comparison 5 Albendazole plus diethylcarbamazine (DEC) versus DEC, Outcome 2 Microfilariae (mf) prevalence: only participants $\mathrm{mf}$ positive at baseline. $\quad . \quad$. . . . . . . . . . . . . . . . . . . . .

Analysis 5.3. Comparison 5 Albendazole plus diethylcarbamazine (DEC) versus DEC, Outcome 3 Antigen prevalence: all participants (both antigen positive and negative at baseline). . . . . . . . . . . . . . . . . . .

Analysis 5.4. Comparison 5 Albendazole plus diethylcarbamazine (DEC) versus DEC, Outcome 4 Antigen prevalence: only participants antigen positive at baseline. . . . . . . . . . . . . . . . . . . . . . . . . 42

Analysis 5.5. Comparison 5 Albendazole plus diethylcarbamazine (DEC) versus DEC, Outcome 5 Adverse events. $\quad . \quad 43$

APPENDICES . . . . . . . . . . . . . . . . . . . . . . . . . . . . . . . . . . . . . . 43

WHAT'S NEW . . . . . . . . . . . . . . . . . . . . . . . . . . . . . . . . . . . . . . . . . 56

HISTORY . . . . . . . . . . . . . . . . . . . . . . . . . . . . . . . . . . . . . . . 56

CONTRIBUTIONS OF AUTHORS . . . . . . . . . . . . . . . . . . . . . . . . . . . . . . . . . . . . . . . 57

DECLARATIONS OF INTEREST . . . . . . . . . . . . . . . . . . . . . . . . . . . . . . . . . . . . . 57

SOURCES OF SUPPORT . . . . . . . . . . . . . . . . . . . . . . . . . . . . . . . . . . . . . . . . . . . . . . . . . 57

DIFFERENCES BETWEEN PROTOCOL AND REVIEW . . . . . . . . . . . . . . . . . . . . . . . 57

INDEX TERMS . . . . . . . . . . . . . . . . . . . . . . . . . . . . . . . . . . . . . . . . . 57 


\section{Albendazole for lymphatic filariasis}

David Addiss ${ }^{2}$, Carrol L Gamble ${ }^{3}$, Paul Garner ${ }^{4}$, Hellen Gelband ${ }^{5}$, Henry OD Ejere ${ }^{6}$, Julia A Critchley ${ }^{1}$, International Filariasis Review Group ${ }^{4}$

${ }^{1}$ Institute of Health and Society, Newcastle University, Newcastle, UK. ${ }^{2}$ Division of Parasitic Diseases, Centers for Disease Control and Prevention, Atlanta, Georgia, USA. ${ }^{3}$ Centre for Medical Statistics and Health Evaluation, University of Liverpool, Liverpool, UK. ${ }^{4}$ International Health Group, Liverpool School of Tropical Medicine, Liverpool, UK. ${ }^{5}$ Resources for the Future, Washington, DC, USA. ${ }^{6}$ Department of Medicine, Metropolitan Hospital, New York, USA

Contact address: Julia A Critchley, Institute of Health and Society, Newcastle University, William Leech Building, The Medical School, Newcastle, Tyne and Wear, NE2 4HH, UK. J.A.Critchley@newcastle.ac.uk.

Editorial group: Cochrane Infectious Diseases Group.

Publication status and date: Edited (no change to conclusions), published in Issue 1, 2009.

Review content assessed as up-to-date: 13 August 2005.

Citation: Addiss D, Gamble CL, Garner P, Gelband H, Ejere HOD, Critchley JA, International Filariasis Review Group. Albendazole for lymphatic filariasis. Cochrane Database of Systematic Reviews 2005, Issue 4. Art. No.: CD003753. DOI: 10.1002/14651858.CD003753.pub3.

Copyright (C) 2009 The Cochrane Collaboration. Published by John Wiley \& Sons, Ltd.

\section{A B S T R A C T}

\section{Background}

Mass treatment with albendazole co-administered with another antifilarial drug is part of a global programme to eliminate lymphatic filariasis. We sought reliable evidence of the effects of albendazole on the disease and the parasite.

\section{Objectives}

To summarize the effects of albendazole alone or in combination with antifilarial drugs for clinical treatment and community control of lymphatic filariasis.

\section{Search strategy}

We searched the Cochrane Infectious Diseases Group Specialized Register (August 2005), CENTRAL (The Cochrane Library Issue 3 , 2005), MEDLINE (1966 to August 2005), EMBASE (1974 to August 2005), LILACS (1982 to August 2005), and reference lists. We also contacted researchers, the World Health Organization, and GlaxoSmithKline.

\section{Selection criteria}

Randomized and quasi-randomized controlled trials of albendazole alone or combined with another antifilarial drug for treating individuals with lymphatic filariasis, or for reducing transmission in endemic communities.

\section{Data collection and analysis}

Two authors independently assessed eligibility and trial quality, and extracted data. Authors contacted investigators for missing information or clarification. 


\section{Main results}

Seven trials including 6997 participants (995 with detectable microfilariae) met the criteria. A comparison of albendazole and placebo detected no effect on microfilariae prevalence ( 920 participants; 3 trials); one trial (499 participants) reported significantly lower microfilariae density at six months. Albendazole performed slightly worse than ivermectin in two trials (436 participants). Compared with diethylcarbamazine (DEC), two small trials (56 participants) found little difference in microfilariae prevalence over an extended follow up. One larger trial (502 participants) found a statistically significant effect for DEC at six months, but none at three months.

Microfilariae prevalence and density were statistically significantly lower with the combination of albendazole and ivermectin compared with ivermectin alone in two of three trials (649 participants). Two trials compared albendazole plus DEC with DEC alone and found no statistically significant difference in microfilariae prevalence, though one trial favoured the combination at six months (risk ratio $0.62,95 \%$ confidence interval 0.32 to $1.21 ; 491$ participants). This trial also found a statistically significant reduction in microfilariae density.

\section{Authors' conclusions}

There is insufficient evidence to confirm or refute that albendazole co-administered with DEC or ivermectin is more effective than $\mathrm{DEC}$ or ivermectin alone in clearing microfilariae or killing adult worms. Albendazole combined with ivermectin appears to have a small effect on microfilaraemia, but this was not consistently demonstrated. The effect of albendazole against adult and larval filarial parasites, alone and in combination with other antifilarial drugs, deserves further rigorous research.

\section{PLAIN LANGUAGESUMMARY}

\section{Not enough evidence on effectiveness of the drug albendazole, alone or in combination, for killing or interrupting transmission} of threadlike worms that cause lymphatic filariasis

Filariasis affects about 120 million people in more than 80 countries and is spread by mosquitoes. Adult worms take up residence in lymph channels and when paired, produce larvae that circulate in the blood. The adult worms can live in the lymph system for five years or more. The infection can cause severe disability, due to massive enlargement of limbs, genitals, and breasts. On the other hand, many infected people have no symptoms, but do contribute to the perpetuation of the infection in the community. This review of trials found insufficient evidence to say whether a single dose of the drug albendazole kills the worms, or whether, if given in combination with diethylcarbamazine or ivermectin, it enhances the killing of these worms or the larvae they produce.

\section{B A C K G R O U N D}

\section{Epidemiology}

Lymphatic filariasis is a parasitic infection of threadlike, filarial worms that affects about 120 million people in more than 80 countries (Michael 1996; WHO 2000). Bancroftian filariasis, caused by infection with Wuchereria bancrofti, occurs in tropical regions of Asia, Africa, China, and the Pacific islands, and in parts of the Caribbean and South America. Brugian filariasis is less common, with Brugia malayi occurring in parts of Asia, and Brugia timori in Indonesia (FGN 1996).

Filariasis is transmitted by mosquitoes from a number of genera (including Culex, Anopheles, Mansonia, Ochlerotatus, and Aedes) (Burkot 2002). Female mosquitoes transmit the disease. They are infected when they take blood meals from people with microfilariae (mf), early stage larvae. The larvae develop for about 12 to 15 days in the mosquito to a mature larval stage (Scott 2000). When the mosquito takes a subsequent blood meal, the larvae enter the skin, migrate to the lymph vessels, and develop into adult worms, where male and female worms pair. They later produce mf, which migrate to the blood causing microfilaraemia. The time between being infected and adult worms producing microfilaraemia is estimated to be about 12 months (Mahoney 1971).

Microfilariae move in and out of circulating peripheral blood according to a daily cycle. In most species, mf levels peak during the night, between $10 \mathrm{pm}$ to $4 \mathrm{am}$ (Simonsen 1997), a time when mosquito vectors are actively feeding. In Fiji, Polynesia, and the Philippines some strains of Wuchereria bancrofti mf peak during 
the day (Scott 2000).

\section{Clinical features}

Many people with filariasis may be asymptomatic most of the time. However, even people without clinical symptoms often have lymphatic changes, including lymphangiectasia (widening of the lymphatic vessels) and thickening of the spermatic cord (Addiss 2000; Dreyer 2000), which can be detected through imaging studies. Clinical symptoms and signs include hydrocoele (excess fluid inside the scrotal sac), lymphoedema (swelling and enlargement of affected areas of the body), and elephantiasis (long standing enlargement and swelling of the limbs, scrota, or breasts associated with skin thickening)

Historically, filarial infection has been diagnosed by examining a blood smear for mf, but, even if blood is taken at night, not all infections are detected because $\mathrm{mf}$ levels are very low in many people. Antigen assays, which became available for field use during the 1990s, are more sensitive and can be used for blood collected during the day or night (Weil 1997) because they indicate the presence of the adult worm and do not depend on the temporal presence of mf. Ultrasound imaging can demonstrate the presence of live adult worms (Dreyer 1995).

How the filarial worm causes disease is not well understood. The following have been proposed: adult worms living in and damaging lymph vessels; immunologic reactions to the presence and death of filarial worms; secondary infections of affected areas, which contribute significantly to both acute and chronic disease manifestations (Dreyer 2000). Researchers have also suggested that toxins released by Wolbachia (endosymbiotic bacteria found within the cells of filarial worms) cause disease (Taylor 2001). Some or all of these processes may be important.

\section{Control}

Control strategies aim to reduce $\mathrm{mf}$ in the community to levels that prevent transmission (Ottesen 1997; Ottesen 1999). Treatment of individuals with clinical disease is generally only partially effective (at least in part because there is no drug that reliably kills the 'macrofilariae', the adult worms). Mass drug administration programmes therefore aim for a sustainable reduction in community mf loads below a critical threshold or a complete clearance of $\mathrm{mf}$ to have an appreciable impact on transmission. The Global Programme to Eliminate Lymphatic Filariasis recommends yearly, single-dose, two-drug regimens (albendazole plus diethylcarbamazine or albendazole plus ivermectin) for at least five years (corresponding to the reproductive lifespan of the adult worm) to prevent transmission. However, the critical threshold below which no further transmission will take place is unclear and may depend on the vector species in the locality. Some mosquitoes (eg Aedes polynesiensis, some culicine mosquitoes in India and the Americas) may be more efficient at lower $\mathrm{mf}$ densities (a process known as limitation). Higher treatment coverage for longer periods or other strategies such as vector control may be required in areas where these vectors are responsible for a high proportion of transmission (Burkot 2002; Pichon 2002).

Ivermectin and diethylcarbamazine (DEC) both kill $\mathrm{mf}$. DEC may have some temporary sterilizing effects or actually kill adult worms, so one treatment with either drug can affect mf levels for many months. Reductions of $90 \%$ from pretreatment $\mathrm{mf}$ levels have been seen after a single dose of DEC or ivermectin even one year after treatment (Ottesen 1999). The impact of drug treatment on transmission can be enhanced, if currently available antifilarial drugs demonstrate a killing or sterilizing effect on adult worms, in addition to their effect on $\mathrm{mf}$. There are concerns that an over reliance on a limited range of drugs may eventually cause resistance, although there is little direct evidence that this is currently a problem in filariasis (Barat 1997; Geerts 2001).

It has been observed that some infected people lose their $\mathrm{mf}$ in the absence of treatment (Vanamail 1990). However, overall mf prevalence rates are believed to be relatively stable over time in endemic communities in the absence of community treatment (Meyrowitsch 1995); new microfilaraemic infections replace those whose microfilaraemia subsides (Vanamail 1990; Weil 1999). Nevertheless, lymphatic filariasis has been eradicated using vector control methods from some areas such as the Solomon Islands, Australia (Burkot 2002; Pichon 2002), and parts of China using DECfortified salt and other DEC regimens (Gelband 1994).

\section{DEC and ivermectin}

DEC has been in use for filariasis for more than 50 years. In the early years of control the recommended regimen for DEC was 6 $\mathrm{mg} / \mathrm{kg}$ daily for 12 days (WHO 1984). Later, clinical and community trials determined that single doses given at various intervals - weekly, monthly, annually, and biannually - were equally effective (Andrade 1995; Eberhard 1989; Simonsen 1995). There is reasonable evidence from ultrasound and clinical observations that DEC kills some adult worms (macrofilariae) after single doses (Addiss 2000; Figueredo-Silva 1996; Noroes 1997).

Ivermectin is used for the treatment and community control of onchocerciasis (caused by another filarial worm, Onchocerca volvulus). It has also been effective in community control programs for lymphatic filariasis (Cao 1997; Cartel 1990; Coutinho 1994). It can be used in many places, but it is particularly important in areas where both onchocerciasis and lymphatic filariasis coexist because DEC can cause eye damage if given to individuals with onchocerciasis. However, recent ultrasound studies suggest that adult worms are not killed by ivermectin, even at high doses over a period of six months (Addiss 2000; Dreyer 1996).

Adverse effects of antifilarial drugs can be serious (though almost never fatal) and prevent people from completing treatment. The most serious appear to be due to a host immunologic reaction to 
the dying worms (Dreyer 1994; WHO 1984). These effects include fever, headache, malaise, muscle pain, and blood in urine. Local effects include localized pain, tender nodules, lymphadenitis (inflammation of the lymph nodes), and lymphangitis (inflammation of lymph vessels) (Addiss 2000).

\section{Albendazole}

Albendazole has been used widely to treat intestinal parasites since the late 1980s and may have a potential role in lymphatic filariasis control (Ottesen 1999). A report from an informal consultation organised by the World Health Organization suggests that repeated high doses of albendazole have a killing or sterilizing effect on W. bancrofti adult worms (CDS/FIL 1998). However, the data in the report are scanty and it remains unclear whether adding albendazole to either DEC or ivermectin improves cure, prevents further transmission, or influences the occurrence of adverse events. A narrative review by Horton 2000 from GlaxoSmithKline, which manufactures albendazole, did not demonstrate that adding albendazole to either drug increased the frequency or severity of adverse events. GlaxoSmithKline states that albendazole does not have a role in morbidity management - it will not treat the symptoms in people already affected by filariasis (GlaxoSmithKline 2003). But at least one trial has considered the effectiveness of albendazole in reducing both disease progression and incidence of new symptoms (such as hydrocoele) (Dunyo 2000). We therefore include this as a secondary outcome.

A recently published review concluded that co-administration of albendazole was more effective in reducing $\mathrm{mf}$ prevalence than one antifilarial drug alone (Gyapong 2005). This review had included observational data and did not assess the quality of the studies, whilst our analysis included only higher quality randomized controlled trials. Most importantly, Gyapong 2005 incorporated data from several studies twice (by counting results at six and twelve months and combining them in the same meta-analysis), which artificially narrows the $95 \%$ confidence intervals. This resulted in the authors erroneously concluding that overall the effect was 'statistically significant' (Gyapong 2005).

In this review, we aim to summarize the evidence for the effects of albendazole alone or in combination with DEC or ivermectin in both the individual treatment and transmission control of lymphatic filariasis.

\section{O B JE C T IVES}

1. To assess the effects of albendazole on individuals or populations with filarial infection.

2. To assess the effects of albendazole on morbidity among individuals with filarial infection (incidence of new disease or progression of existing symptoms).
3. To assess the frequency of adverse events for albendazole both given singly or in combination with another antifilarial drug (DEC or ivermectin).

\section{METHODS}

\section{Criteria for considering studies for this review}

\section{Types of studies}

Randomized controlled trials; cluster-randomized controlled trials; and quasi-randomized controlled trials.

\section{Types of participants}

- Adults or children with filarial infection defined by the presence of $\mathrm{mf}$ parasites in the blood, filarial antigens in the blood, or ultrasound detection of adult worms in lymphatic vessels.

- Populations normally resident in endemic communities and who are eligible for treatment regardless of microfilaraemia status (community trials).

\section{Types of interventions}

- Albendazole alone versus placebo.

- Albendazole alone versus DEC.

- Albendazole alone versus ivermectin.

- Albendazole plus DEC versus DEC (DEC dose and regimen same in both arms).

- Albendazole plus ivermectin versus ivermectin (ivermectin dose and regimen same in both arms).

\section{Types of outcome measures}

\section{Primary}

- Mf prevalence.

- Mf density.

- Community mf density (in mass treatment trials).

- Antigenaemia prevalence or density.

- Adult worms (macrofilariae viability detected by ultrasound). 


\section{Secondary}

- Acute filariasis (fever plus clinical evidence of inflammation of the lymphatic system, as defined by primary investigators).

- Appearance or disappearance of hydrocoele or lymphoedema.

- Reduction in size (or severity or grade) of hydrocoele or lymphoedema.

\section{Adverse events}

- Adverse events that prevent daily activities or require hospitalization.

- Systemic adverse events (eg fever, headache, malaise, myalgia, or haematuria).

- Local adverse events (eg localized pain and inflammation, tender nodules, lymphadenitis, or lymphangitis).

\section{Search methods for identification of studies}

We attempted to identify all relevant trials regardless of language or publication status (published, unpublished, in press, and in progress).

\section{Databases}

We searched the following databases using the search terms and strategy described in Appendix 1: Cochrane Infectious Diseases Group Specialized Register (August 2005); Cochrane Central Register of Controlled Trials (CENTRAL), published in The Cochrane Library (Issue 3, 2005); MEDLINE (1966 to August 2005); EMBASE (1974 to August 2005); and LILACS (1982 to August 2005).

\section{Researchers, organizations, and pharmaceutical companies}

We contacted individual researchers working in the field, the World Health Organization, and GlaxoSmithKline (the company producing albendazole) for unpublished and ongoing trials.

\section{Reference lists}

We also checked the reference lists of all studies identified by the above methods.

\section{Data collection and analysis}

\section{Selection of studies}

One author (Henry Ejere (HE) or Julia Critchley (JC)) screened titles and abstracts identified from the search strategy. Hard copies of the published or unpublished trial reports potentially relevant to the review were retrieved for further assessment. Two authors (HE or JC and Paul Garner (PG)) independently used a predesigned eligibility form to select trials that met the inclusion criteria. Disagreements were resolved through discussion.

\section{Data extraction and management}

One author (HE or JC) extracted data, which a second author (PG) checked. Where trials reported the same outcomes in different ways, we attempted to contact the primary investigators for further information, which might allow transformation of data. We extracted data relating to trial and participant characteristics, and reported outcome measures. We intended to extract data to allow an intention-to-treat analysis (all the participants analysed according to the intervention to which they were originally allocated, whether they received it or not). This was not possible, but may be attempted in future updates. Where the numbers randomized and the numbers analysed for each outcome were inconsistent, we calculated the percentage loss to follow up and recorded this information in Appendix 2. For dichotomous outcomes, we recorded the number of participants experiencing the event in each group of the trial. For continuous outcomes, we extracted arithmetic means and standard deviations. Where geometric means were reported, we extracted and recorded this information. We also tried to extract confidence intervals or standard deviations on the log scale. One author (HE or JC) entered data into Review Manager 5.

\section{Assessment of risk of bias in included studies}

Two authors (HE or JC and PG) independently assessed trials according to predefined quality criteria. We assessed the generation of allocation sequence and concealment of allocation to be adequate, inadequate, or unclear according to Jüni 2001. We assessed blinding as double blind (trial uses a placebo or a double dummy technique such that neither the participant or care provider/assessor knows which treatment is given), single blind (participant or care provider/assessor is aware of the treatment given), or open (all parties are aware of the treatment). We assessed the inclusion of all randomized participants in the analysis to be adequate if $90 \%$ or more were included.

\section{Data synthesis}

We grouped the trials by the main comparator interventions, such as albendazole versus placebo. Within comparator groups, we stratified trials into those of treatment in individuals and trials of mass treatment in communities. Where appropriate we combined trials in a meta-analysis using a fixed-effect model. We calculated risk ratios (RR) for dichotomous outcomes and used $95 \%$ confidence 
intervals. We reported medians and ranges in tables only. We assessed heterogeneity by visually inspecting forest plots and carrying out a chi-squared test for heterogeneity (statistical significance at $10 \%$ level). We used the random-effects model to pool data where we detected heterogeneity. Too few trials were available to examine heterogeneity in any more detail, but this might be possible in future updates.

\section{RE S U L T S}

\section{Description of studies}

See: Characteristics of included studies; Characteristics of excluded studies; Characteristics of ongoing studies.

\section{Trial selection}

We identified 12 published trials of which seven met the inclusion criteria (see'Characteristics of included studies'). We excluded five studies reported in eight publications (see 'Characteristics of excluded studies'). We are aware of one ongoing study (see 'Characteristics of ongoing studies').

\section{Study design and location}

All the trials randomized individual participants. The length of the follow up varied: four months (Beach 1999); six months ( Fox 2005); 12 months (Dunyo 2000; Kshirsagar 2004; Simonsen 2004); 19 months (Jayakody 1993); and two years (Pani 2002). The trials were conducted in southern Ghana (Dunyo 2000), Haiti (Beach 1999; Fox 2005), India (Kshirsagar 2004; Pani 2002), Sri Lanka (Jayakody 1993), and Tanzania (Simonsen 2004).

\section{Participants}

Nine-hundred and ninety five of the 6997 randomized participants had detectable mf. Jayakody 1993 and Pani 2002 enrolled people who were mf positive. Dunyo 2000, Beach 1999, Simonsen 2004, and Fox 2005 enrolled people regardless of $\mathrm{mf}$ status at baseline. Kshirsagar 2004 enrolled 1403 participants for a safety study and included 103 of these in a separate analysis of efficacy. Forty-three of the 103 were $\mathrm{mf}$ positive, 30 had clinical disease, and 30 were $\mathrm{mf}$ negative and asymptomatic. However, at most time points, $\mathrm{mf}$ prevalence results were only available for the 43 mf-positive participants.

\section{Intervention}

The trials addressed all the pre-specified comparisons: albendazole alone versus placebo (Beach 1999; Dunyo 2000; Fox 2005); albendazole alone versus DEC (Fox 2005; Jayakody 1993; Pani 2002); albendazole alone versus ivermectin (Beach 1999; Dunyo 2000); albendazole plus DEC versus DEC (Fox 2005; Kshirsagar 2004; Pani 2002); and albendazole plus ivermectin versus ivermectin (Beach 1999; Dunyo 2000; Simonsen 2004).

All the trials used the same albendazole dose $(400 \mathrm{mg})$. The three trials using ivermectin had different doses: 200 to $400 \mu \mathrm{g} / \mathrm{kg}$ ( Beach 1999); and 150 to $200 \mu \mathrm{g} / \mathrm{kg}$ (Dunyo 2000; Simonsen 2004). The DEC dose was $6 \mathrm{mg} / \mathrm{kg}$ body weight. The drugs were given as a single treatment in all trials except for Jayakody 1993 in which DEC was given daily and albendazole twice daily for 21 days.

\section{Outcomes}

All trials reported on $\mathrm{mf}$. The methods of measurement varied, including prevalence in $20 \mu \mathrm{L}$ of blood (Beach 1999), prevalence and density in $20 \mu \mathrm{L}$ of blood (Fox 2005), prevalence in $60 \mu \mathrm{L}$ of blood (Kshirsagar 2004), prevalence in $1 \mathrm{~mL}$ of venous blood (Pani 2002), and prevalence in $1 \mathrm{~mL}$ blood using membrane filtration ( Jayakody 1993), or prevalence in $100 \mu \mathrm{L}$ using a counting chamber (Dunyo 2000; Simonsen 2004); see Appendix 3 and Appendix 5 for $\mathrm{mf}$ prevalence and $\mathrm{mf}$ density, respectively.

Several trials also reported antigen prevalence or density (Dunyo 2000; Fox 2005; Kshirsagar 2004; Pani 2002; Simonsen 2004); see Appendix 4 and Appendix 6. Two trials determined the effect of treatment on adult worms by ultrasound scan for a subgroup of participants (Kshirsagar 2004; Pani 2002); see Appendix 7.

All trials reported adverse events, but the methods of reporting varied (see 'Characteristics of included studies' and Appendix 8).

\section{Reported statistical analysis}

Standard deviations or confidence intervals were not reported for $\mathrm{mf}$ density outcomes; this information was obtained from the investigators for Fox 2005. As so few trials reported standard deviations, we could not pool results for changes in mf density; results quoted in this review are the original trial author's calculations. Two trials, Jayakody 1993 and Pani 2002, did not clearly describe the method of calculating reductions in geometric mean $\mathrm{mf}$ density, but Pani 2002 provided further details on request. This trial calculated a William's mean (a modification of the geometric mean to take into account zero counts) (Basanez 1994) on the pretreatment and post-treatment $\mathrm{mf}$ densities. Dunyo 2000 calculated change in mf density by two methods the Williams mean and by using an 'area under the curve' analysis (an average density over the whole 12 month post-treatment period). Simonsen $2004 \mathrm{cal}-$ culated a William's mean and estimated the combined effect over the one-year follow-up period using repeated measures techniques 
(either ANOVA or generalized estimating equations). Beach 1999 and Fox 2005 calculated the geometric mean mf density reduction by dividing the difference between densities before and after treatment by the pretreatment $\mathrm{mf}$ density and $\log$ transforming the results. If pretreatment $\mathrm{mf}$ density was less than the density after treatment, the reduction was deemed to be zero. The trialists performed this adjustment to eliminate the problem of log transforming a negative value, but this method may bias estimates of treatment effectiveness, as increases in mf density after treatment are set to zero. For this reason, for Beach 1999, we present the trialists' results in the text and the percentage change using the group means in tables. The Fox 2005 trial authors recalculated geometric mean changes taking into account children where $\mathrm{mf}$ density increased post-treatment at our request (although estimates do not include children newly infected over the course of the trial), and we report these revised figures.

\section{Risk of bias in included studies}

See the 'Characteristics of included studies' for details and Appendix 2 for a summary.

\section{Generation of allocation sequence}

All trials were described as randomized, but Pani 2002 and Kshirsagar 2004 did not describe a method of randomization, and Jayakody 1993 only stated that the list was predetermined and restricted.

\section{Allocation concealment}

Beach 1999, Dunyo 2000, Pani 2002, and Simonsen 2004 used a third party in the allocation process to conceal allocation. Allocation concealment was unclear in the other trials.

\section{Blinding}

Five of the trials were double blind (Beach 1999; Dunyo 2000; Kshirsagar 2004; Pani 2002; Simonsen 2004). The outcome assessors were blinded in Fox 2005, and Jayakody 1993 did not mention blinding.

\section{Inclusion of randomized participants in the analysis}

Losses of participants during the follow-up period were significant in most of the trials. In Dunyo 2000, 1181 (82.9\%) of the 1425 participants were re-examined at 12 months; 67 of the $340 \mathrm{mf}-$ positive participants (20\%) were also lost to follow up. Beach 1999 excluded 380 of 965 (39\%) randomized participants who did not have both pretreatment and post-treatment blood examinations. However, there were few losses among the $\mathrm{mf}$ positive participants at baseline (3/113). In Jayakody 1993, six of 16 (37.5\%) men allocated to albendazole and three of 13 (23\%) allocated to DEC were lost to follow up by 15 to 19 months. Pani 2002 reported no losses to follow up. Fox 2005 reported on 990 of 1292 (24\% lost) originally randomized. Simonsen 2004 analysed 1221 of 1829 (33\% lost) randomized. Kshirsagar 2004 included only 103 of 1403 participants in the efficacy analysis ( 43 of whom were $\mathrm{mf}$ positive, 30 had clinical disease, and 30 were asymptomatic $\mathrm{mf}$ negative).

\section{Effects of interventions}

\section{Albendazole versus placebo}

\section{Mf prevalence: all participants ( $\mathrm{mf}$ positive or negative at baseline)}

Two trials, Beach 1999 and Fox 2005, did not detect a statistically significant difference after three to four months (783 participants). There was also no statistically significant difference in prevalence in the one trial that reported at six months (Fox 2005). See Analysis 1.1 .

\section{Mf prevalence: only participants $\mathrm{mf}$ positive at baseline}

Beach 1999 found no statistically significant difference in the prevalence between albendazole (22/29) and placebo (20/29) at four months. Similarly, Dunyo 2000 found no statistically significant difference between albendazole (62/71) and placebo (62/ 66) at 12 months. A combined estimate from these two trials also shows no statistically significant difference (RR 0.97, 95\% CI 0.87 to $1.09 ; 195$ participants). See Analysis 1.2.

\section{Antigen prevalence: all participants ( $\mathrm{mf}$ positive or negative at baseline)}

There were no statistically significant differences in the prevalence of circulating filarial antigen positivity from two trials (Dunyo 2000; Fox 2005) after six to 12 months (1090 participants). See Analysis 1.3.

\section{Mf density: all participants ( $\mathrm{mf}$ positive or negative at baseline)}

Fox 2005 reported a reduction in $\mathrm{mf}$ density at three and six months. The three-month reduction was by $8.2 \%$ (from 17.3 to $8.7 \mathrm{mf} / 20 \mu \mathrm{L}$ ) in the placebo group compared with $22 \%$ (from 12.1 to $4.7 \mathrm{mf} / 20 \mu \mathrm{L}$, not significant) in the albendazole group. At six months, it had reduced by $10.3 \%(17.3$ to $11.2 \mathrm{mf} / 20 \mu \mathrm{L})$ in the placebo group compared with $34.7 \%$ (12.1 to $4.7 \mathrm{mf} / 20$ $\mu \mathrm{L})(\mathrm{P}<0.05)$ in the albendazole group. See Appendix 5. 


\section{Mf density: only participants mf positive at baseline}

Beach 1999 estimated the reduction in geometric mean mf density at four months - $63.8 \%$ (from 14.1 to $5.1 \mathrm{mf} / 20 \mu \mathrm{L}$ ) in the albendazole group and $43.0 \%$ (from 9.3 to $5.3 \mathrm{mf} / 20 \mu \mathrm{L}$ ) in the placebo group; this reduction was not statistically significant. Dunyo 2000 reported a reduction in the geometric mean $\mathrm{mf}$ density between baseline and 12 months of $68.5 \%$ (from 798 to 251 $\mathrm{mf} / 100 \mu \mathrm{L}$ ) in the albendazole group compared with $13 \%$ (from 971 to $845 \mathrm{mf} / 100 \mu \mathrm{L}$ ) in the placebo group, but this was not statistically significant $(\mathrm{P}=0.10)$. An 'area under the curve' analysis from this trial found an $8.4 \%$ increase in geometric mean mf density in the placebo group (from 2536 to $2750 \mathrm{mf} / 100 \mu \mathrm{L}$ ) and a $19.7 \%$ decrease in the albendazole group (from 1535 to $1233 \mathrm{mf}$ / $100 \mu \mathrm{L})$; again this was not statistically significant $(\mathrm{P}=0.12)$. This latter analysis was limited to those with a complete data collection and a $\mathrm{mf}$ density of over $100 \mathrm{mf} / \mathrm{mL}$ at baseline. See Appendix 5 .

\section{Antigen density: all participants ( $\mathrm{mf}$ positive or negative at baseline)}

There were no statistically significant differences in the geometric mean percent reduction in antigen density after six months in the albendazole group (3.2\%) and the placebo group (1.7\%) in Fox 2005. See Appendix 6.

\section{Antigen density: only participants $\mathrm{mf}$ positive at baseline}

Dunyo 2000 reported that the geometric mean $\mathrm{mf}$ density of the circulating filarial antigen unit had increased to $147.5 \%$ of the pretreatment level in the placebo group, but it decreased to $83.1 \%$ of the pretreatment level in the albendazole group; the difference was not statistically significant $(P=0.11)$. See Appendix 6 .

\section{Clinical disease: new and pre-existing}

Twelve months after treatment Dunyo 2000 detected no statistically significant difference in the development of hydrocoele between participants in the albendazole group (1/129) and placebo group (1/126). No new cases of acute filariasis and leg lymphoedema were observed. Similarly, there were no statistically significant differences in the improvement of symptoms in lymphoedema between the albendazole group (3/13) and the placebo group (2/9), or in hydrocoele between the albendazole group (3/ 8 ) and placebo group (5/10). Although we did not detect statistically significant differences, the trials lacked power for clinical outcomes so clinically important differences cannot be ruled out. See Analysis 1.4 and Analysis 1.5.

\section{Adverse events}

Dunyo 2000 did not detect a statistically significant difference in systemic adverse events between the albendazole group (31/
336) and the placebo group (33/314). No local or severe adverse events were reported. Fox 2005 reported statistically significant reductions in myalgias and cough for albendazole compared with placebo, but no statistically significant differences in headache, fever, or mean treatment impact score. See Analysis 1.6 and Appendix 8.

\section{Albendazole versus ivermectin}

\section{Mf prevalence: all participants ( $\mathrm{mf}$ positive or negative at baseline)}

Beach 1999 did not demonstrate a statistically significant difference between the albendazole group (22/145) and ivermectin group (20/150). See Analysis 2.1.

\section{Mf prevalence: only participants $\mathrm{mf}$ positive at baseline}

Beach 1999 reported $\mathrm{mf}$ prevalence at four months of follow up: $22 / 29$ in the albendazole group and 17/28 in the ivermectin group. Dunyo 2000 also reported this outcome: 62/71 in the albendazole group and 52/70 in the ivermectin group. Pooling the two trials, albendazole was slightly poorer in clearing $\mathrm{mf}$, but this only just reached statistical significance (RR $0.84,95 \%$ CI 0.72 to 0.98 ; 198 participants). See Analysis 2.2.

\section{Antigen prevalence: all participants ( $\mathrm{mf}$ positive or negative} at baseline)

Dunyo 2000 reported no statistically significant difference in the number of participants positive for circulating filarial antigen at baseline or after 12 months for those treated with albendazole (105 and 110) or ivermectin (99 and 101). See Analysis 2.3.

\section{Mf density: only participants $\mathrm{mf}$ positive at baseline}

Beach 1999 reported on the percentage reduction in geometric mean mf density between baseline and four months follow up. There was a reduction of $28.7 \%(14.1$ to $5.1 \mathrm{mf} / 20 \mu \mathrm{L})$ for the albendazole group and of $76.1 \%(15.5$ to $1.5 \mathrm{mf} / 20 \mu \mathrm{L})$ for the ivermectin group, $\mathrm{P}=0.02$. Dunyo 2000 measured mean values at baseline and 12 months follow up, which changed from 798 to $251 \mathrm{mf} / 100 \mu \mathrm{L}(68.5 \%$ reduction) for albendazole and from 640 to $124 \mathrm{mf} / 100 \mu \mathrm{L}$ ( $80.6 \%$ reduction) for ivermectin; no statistical significance test was reported. An 'area under the curve' analysis from this trial found a $19.7 \%$ decrease in the albendazole group (from 1535 to $1233 \mathrm{mf} / 100 \mu \mathrm{L}$ ) and a $56.2 \%$ decrease in the ivermectin group (from 1731 to $759 \mathrm{mf} / 100 \mu \mathrm{L}$ ). This latter analysis was limited to those with complete data collection and a $\mathrm{mf}$ density of more than $100 \mathrm{mf} / \mathrm{mL}$ at baseline. See Appendix 5 . 


\section{Antigen density: only participants $\mathrm{mf}$ positive at baseline}

Dunyo 2000 reported that the geometric mean mf density of the circulating filarial antigen unit had decreased to $83.1 \%$ of the pretreatment level in the albendazole group and $70.3 \%$ in the ivermectin group (no statistical test applied). See Appendix 6.

\section{Clinical disease}

Dunyo 2000 found no statistically significant differences in the risk of developing hydrocoele (1/129 albendazole and 1/133 ivermectin), improvements in lymphoedema (3/13 albendazole and $2 / 13$ ivermectin), and improvements in hydrocoele (3/8 albendazole and 2/9 ivermectin), but sample sizes were small and confidence intervals wide. See Analysis 2.4 and Analysis 2.5.

\section{Adverse events}

Dunyo 2000 did not detect a statistically significant difference in the number of systemic adverse events between the albendazole group (31/336) and ivermectin group (36/295). See Analysis 2.6.

\section{Albendazole plus ivermectin versus ivermectin}

\section{Mf prevalence: all participants ( $m f$ positive or negative at baseline)}

Beach 1999 estimated a statistically significant 65\% reduction in $\mathrm{mf}$ prevalence for the combination (7/151) compared with ivermectin alone (20/150). See Analysis 3.1.

\section{Mf prevalence: only participants mf positive at baseline}

Beach 1999 reported a 73\% reduction in $\mathrm{mf}$ at four months for the combination compared with ivermectin alone (4/24) $\mathrm{mf}$ positive at four months for the combination compared with (17/28) for ivermectin alone). Simonsen 2004 reported a smaller reduction at six months (203 participants). Overall, there was no statistically significant difference at four to six months (RR 0.49, 95\% CI 0.18 to 1.39 , random-effects model; 255 participants).

Two trials reported on this outcome at 12 months (Dunyo 2000; Simonsen 2004). Both trials found no statistically significant difference between the combination and ivermectin (RR 1.00, 95\% CI 0.88 to 1.13 ; 348 participants). See Analysis 3.2.

\section{Antigen prevalence: all participants ( $m f$ positive or negative at baseline)}

Dunyo 2000 reported no statistically significant difference in the numbers positive for circulating filarial antigen at baseline or 12 months (121 to 122 for albendazole plus ivermectin; 99 to 101 for ivermectin alone). See Analysis 3.3.

\section{Antigen prevalence: only participants antigen positive at baseline}

Neither Dunyo 2000 nor Simonsen 2004 reported any statistically significant differences at six or 12 months. See Analysis 3.4.

\section{Mf density: only participants mf positive at baseline}

Beach 1999 reported a reduction in the geometric mean mf density at four months of $98.9 \%$ for the combination group compared with $76.1 \%$ for the ivermectin group $(\mathrm{P}<0.05)$.

Dunyo 2000 reported that the reduction in geometric mean $\mathrm{mf}$ density in both groups after 12 months was $87.3 \%$ for the combination and $80.6 \%$ for ivermectin, but it was not statistically significant $(\mathrm{P}=0.80)$. An 'area under the curve' analysis from this trial found that the $69.3 \%$ decrease in the combination group (from 1280 to $393 \mathrm{mf} / 100 \mu \mathrm{L}$ ) and the $56.2 \%$ decrease in the ivermectin group (from 1731 to $759 \mathrm{mf} / 100 \mu \mathrm{L}$ ) was also not statistically significant $(\mathrm{P}=0.26)$. This latter analysis was limited to those with complete data collection and a mf density of over $100 \mathrm{mf} / \mathrm{mL}$ at baseline.

Simonsen 2004 reported reductions in the geometric mean $\mathrm{mf}$ density in the ivermectin group of $80.4 \%$ at six months and $83.6 \%$ at 12 months. The reductions were greater in the combination group, $96.3 \%$ at six months and $92.6 \%$ at 12 months. A repeated measures ANOVA demonstrated a statistically significantly higher rate of reduction in the combination group $(\mathrm{P}<0.0001)$. See Appendix 5.

\section{Antigen density: only participants antigen positive at baseline}

There were no significant differences in the percentage reduction in antigen density for the combination group (59.3\%) compared with ivermectin (70.3\%) $(\mathrm{P}=0.8)$. See Appendix 6 .

\section{Clinical disease}

Dunyo 2000 found no statistically significant difference in the number of new cases of hydrocoele between the combination group (2/147) and the ivermectin group (1/133). This trial also observed no statistically significant differences in the improvement of lymphoedema (2/13 in combination group and $2 / 13$ in ivermectin group) and hydrocoele (4/10 in combination group and $2 / 9$ in ivermectin group). Again, the trials were not designed to detect changes in clinical outcomes; therefore confidence intervals are very wide. See Analysis 3.5 and Analysis 3.6.

\section{Adverse events}

Dunyo 2000 recorded more adverse events with the combination treatment (47/332) compared with ivermectin (36/295), but this was not statistically significant. See Analysis 3.7 and Appendix 8. 


\section{Albendazole versus DEC}

Two of the three trials that made this comparison were very small and recruited only participants who were $\mathrm{mf}$ positive at baseline (Jayakody 1993; Pani 2002). Jayakody 1993 compared albendazole (16 participants) with DEC (13 participants) and attempted to follow the participants for 19 months. They reported that all participants in this extended follow up lived nearby and had received treatment in addition to the study intervention, but they did not report the specifics of the additional treatment. Pani 2002 compared albendazole (19 participants) DEC (17 participants), and albendazole plus DEC co-administered (18 participants). The third trial, Fox 2005, was larger and included children irrespective of $\mathrm{mf}$ status from an endemic community.

\section{Mf prevalence: all participants ( $\mathrm{mf}$ positive or negative at baseline)}

Fox 2005 found no statistically significant difference at three months, but there was a statistically significant difference in favour of DEC at six months (RR 1.74, 95\% CI 1.05 to 2.88; 502 participants). See Analysis 4.1.

\section{Mf prevalence: only participants mf positive at baseline}

Pani 2002 reported no statistically significant difference at 90 days or 360 days for albendazole (5/19) or DEC (3/17). Jayakody 1993 stated that $85 \%$ (numerator and denominator unclear) of the albendazole-treated participants and $67 \%(8 / 12)$ of the DECtreated participants still had detectable $\mathrm{mf}$ at six months. After 15 to 19 months, $50 \%$ (5/10 for both groups) of participants in both groups were $\mathrm{mf}$ positive, but a substantial proportion of the participants had been lost during this follow-up period. Pani 2002 continued to follow the participants for up to two years, but they found no statistically significant difference in $\mathrm{mf}$ prevalence at this time. See Analysis 4.2.

\section{Antigen prevalence: all participants ( $m f$ positive or negative at baseline)}

Fox 2005 found no statistically significant difference in antigen prevalence at six months. See Analysis 4.3.

\section{Antigen prevalence: only participants $\mathrm{mf}$ positive at baseline}

Pani 2002 reported no statistically significant difference in the prevalence of filarial antigenaemia at any point during the trial $(\mathrm{P}$ $>0.05)$. The percentage reduction measured using immunochromatographic test (ICT) was $83 \%$ with albendazole and $87 \%$ with DEC; using $\mathrm{Og} 4 \mathrm{C} 3$, it was $83 \%$ with albendazole and $80 \%$ with DEC. See Analysis 4.4.

\section{Mf density: all participants ( $\mathrm{mf}$ positive or negative at baseline)}

Fox 2005 reported a fall in the geometric mean mf density in both groups from baseline to three months to six months. The percentage reduction at six months was $34.7 \%$ for the albendazole group and $50.4 \%$ for the DEC group, but this difference was not statistically significant. See Appendix 5.

\section{Mf density: only participants mf positive at baseline}

Pani 2002 reported no statistically significant difference in percentage reductions in geometric mean $\mathrm{mf}$ density at any of the time points this was measured (days 3, 7, and 360). The mf density appeared to fall faster during the first seven days with DEC compared with albendazole.

Jayakody 1993 also found large reductions in geometric mean mf density at six months for both treatment groups: $1.9 \%$ of its initial value for those treated with albendazole and $0.81 \%$ for those treated with DEC. After 15 to 19 months of follow up there was no statistically significant difference (geometric mean mf density $3 \mathrm{mf} / \mathrm{mL}$ for albendazole and $2 \mathrm{mf} / \mathrm{mL}$ for DEC). Similarly to Pani 2002, the mf density appeared to fall faster during the first 28 days with DEC compared with albendazole. See Appendix 5.

\section{Antigen density: all participants ( $m f$ positive or negative at baseline)}

Fox 2005 reported that after six months the geometric mean antigen density was reduced by $17 \%$ in the DEC group compared with $3.2 \%$ in the albendazole group $(\mathrm{P}<0.05)$. See Appendix 6 .

\section{Antigen density: participants $\mathrm{mf}$ positive at baseline}

Pani 2002 found statistically significant reductions in mean optical antigen density by $\mathrm{Og} 4 \mathrm{C} 3$ assay in both groups at 360 days: 0.41 with albendazole $(\mathrm{P}<0.0001)$ and 0.32 with $\mathrm{DEC}(\mathrm{P}<0.0001)$. See Appendix 6.

\section{Adult worms}

Pani 2002 reported no statistically significant differences in detection of adult worms by ultrasonography at one or two years, but only a small number of participants were included in this analysis. See Appendix 7.

\section{Adverse events}

Pani 2002 reported no life-threatening adverse events in any group. Those observed were transient (not lasting beyond six days) and included fever, myalgia, and headache. There was no statistically significant difference in the proportion reporting any systemic adverse events between albendazole (8/19) and DEC (9/17). The 
mean score of adverse reaction intensity was lower for albendazole compared with DEC $(\mathrm{P}<0.05)$, but the validity and clinical significance of this scoring system was uncertain.

Jayakody 1993 reported that 11 of 15 participants receiving the full treatment regimen for albendazole developed 'scrotal syndrome', which was classified as 'severe' for two men, moderate for two, and mild for the other seven. None of the participants on DEC developed similar symptoms. One participant on DEC had fever, right hypochondrial pain, and repeated vomiting, and was withdrawn from the trial. Drug doses were much higher in this trial than in the other three. Participants were given albendazole twice a day or DEC once a day for three weeks unlike the other trials that tested a single dose of albendazole plus DEC or ivermectin.

Fox 2005 reported more myalgias in the DEC group (8/44) than the albendazole group $(1 / 46)(\mathrm{P}<0.05)$, and a higher treatment impact score at days one and two $(\mathrm{P}<0.05)$, but there were no other statistically significant differences between the treatment groups. See Analysis 4.5 and Analysis 4.6, and Appendix 8.

\section{Albendazole plus DEC versus DEC}

\section{Mf prevalence: all participants ( $\mathrm{mf}$ positive or negative at baseline)}

Fox 2005 showed no statistically significant difference in mf prevalence at three months or six months. See Analysis 5.1.

\section{Mf prevalence: only participants mf positive at baseline}

The two trials from India, Kshirsagar 2004 and Pani 2002, reported $\mathrm{mf}$ prevalence at various time points between three months and two years. There were no statistically significant differences at any time point. See Analysis 5.2.

\section{Antigen prevalence: all participants ( $m f$ positive or negative at baseline)}

Two trials, Fox 2005 and Kshirsagar 2004, showed no statistically significant difference in antigen prevalence at either six or 12 months. See Analysis 5.3 and Appendix 4.

\section{Antigen prevalence: only participants antigen positive at baseline}

Pani 2002 reported no statistically significant difference in prevalence of filarial antigenaemia by at any point during the trial ( $\mathrm{P}$ $>0.05$ ). The percentage reduction after one year was $75 \%$ on albendazole plus DEC compared with $87 \%$ on DEC, as measured by immunochromatographic test (ICT), and $81 \%$ on albendazole and DEC compared with $80 \%$ on DEC, as measured by $\mathrm{Og} 4 \mathrm{C} 3$. See Analysis 5.4 and Appendix 4.

\section{Mf density: all participants ( $\mathrm{mf}$ positive or negative at} baseline)

Fox 2005 reported similar geometric mean percent reductions in mf density at three months, but at six months they were statistically significantly greater in the combination arm $(80.4 \%$ compared with $50.4 \%, \mathrm{P}<0.05)$. See Appendix 5.

\section{Mf density: only participants $\mathrm{mf}$ positive at baseline}

Pani 2002 reported no statistically significant difference in percentage reductions in the geometric mean mf density. See Appendix 5.

Antigen density: all participants ( $\mathrm{mf}$ positive or negative) at baseline

After six months, the geometric mean reduction in antigen density was greater in the combination arm (26.7\%) than the DEC arm (17.0\%), but the difference was not statistically significant (Fox 2005). See Appendix 6.

\section{Antigen density: only participants $\mathrm{mf}$ positive at baseline}

Pani 2002 reported statistically significant reductions in mean optical antigen density by $\mathrm{Og} 4 \mathrm{C} 3$ assay in both groups at 360 days compared with the pretreatment value: a reduction of 0.40 with albendazole plus DEC $(\mathrm{P}<0.0001)$ and 0.32 with DEC $(\mathrm{P}<$ $0.0001)$. There were no differences in the reduction in antigen density between the combination and DEC group. See Appendix 6.

\section{Adult worms}

There were no statistically significant differences in detection of adult worms by ultrasonography in Pani 2002 or Kshirsagar 2004, but only a small number of participants were included in this analysis. See Appendix 7.

\section{Adverse events}

Pani 2002 reported no statistically significant difference in the proportion reporting any systemic adverse events (11/18 for albendazole plus DEC and 9/17 for DEC) or in the mean score of adverse reaction intensity (6.7 (sd 6.6) for albendazole plus DEC and 5.6 (sd 7.1) for DEC).

Fox 2005 found no statistically significant differences in specific symptoms or treatment impact scores for the combination compared with DEC alone.

Kshirsagar 2004 assessed adverse drug events in a large sample size (1403 participants). There were no statistically significant differences in the proportion of participants reporting an adverse drug 
reaction by day seven in the DEC group compared with the combination group (128/693 versus 120/702) ), or the proportions experiencing adverse events that interfered with daily activities (29/ $694,4.2 \%$ and $31 / 702,4.4 \%$ respectively). The adverse events generally appeared mild in both arms, with no life-threatening or disabling events (Common Toxicity Criteria grade 4) reported; most were mild or moderate adverse events. See Analysis 5.5 and Appendix 8.

\section{DISCUSSION}

This review was designed to assess the effects of albendazole alone or in combination with the currently recommended antifilarial drugs, ivermectin or DEC. Although the review has considered the effects of albendazole alone, the main interest and strategy of the Global Programme to Eliminate Lymphatic Filariasis is in the effectiveness of combinations of different antifilarial drugs (Ismail 1998; Shenoy 1999). Of particular interest is the effectiveness of adding albendazole (thought to be macrofilaricidal) (CDS/FIL 1998; Jayakody 1993) to single dose regimens of ivermectin (thought to be mainly microfilaricidal) or DEC (possibly both microfilaricidal and macrofilaricidal) (Ottesen 1999).

All the included studies were designed primarily to assess the effectiveness of albendazole for treatment of individuals, and none have explicitly considered its effects on transmission in whole communities. We identified seven trials, but most of these were small. All were described as randomized, but they had important limitations. In particular, the numbers of participants lost to follow up were very high (above 20\%) in all trials except for Pani 2002, and this may lead to imbalances in the comparison groups.

Differences in design ( $\mathrm{mf}$ positive only versus positive and negative participants at baseline, variable outcome measurement and reporting, and follow-up times) make it difficult to compare the trials. In particular, some trials reported outcomes mainly for those who were mf positive at baseline (Dunyo 2000; Kshirsagar 2004; Simonsen 2004). Outcomes for all participants in the trial, regardless of baseline $\mathrm{mf}$ status, are essential in assessing the community impact of mass treatment strategies. Most of the trials reported changes in antigenaemia prevalence or density in addition to $\mathrm{mf}$ prevalence and density (Dunyo 2000; Fox 2005; Kshirsagar 2004; Pani 2002; Simonsen 2004). There was broad agreement between changes in both these outcome measures in these trials. Only two trials objectively examined the effects of antifilarial medication on the viability of adult worms: Kshirsagar 2004 used a sample of the enrolled participants (101 men at baseline) and Pani 2002 used 25 men at baseline. Adult worms are responsible for the production of $\mathrm{mf}$; therefore, the extent to which antifilarial drugs affect worm viability is an important outcome.

Albendazole alone was not effective in reducing $\mathrm{mf}$ prevalence (Beach 1999; Dunyo 2000; Fox 2005) or circulating filarial anti- gens (Dunyo 2000; Fox 2005) compared with placebo. Ivermectin was more effective than albendazole in both of these trials, and a meta-analysis indicates a marginal but statistically significant $16 \%$ reduction in the risk ratio of $\mathrm{mf}$ prevalence after treatment for those who were $\mathrm{mf}$ positive at baseline in favour of ivermectin.

In two trials the combination of albendazole and ivermectin was better than ivermectin alone in the short term (after four to six months follow up; Beach 1999; Simonsen 2004), but they were the same after twelve months of follow up (Dunyo 2000; Simonsen 2004). The lack of measurements at similar intervals in all three trials makes it impossible to know if the results were substantially alike. It is possible that by 12 months mflevels had risen sufficiently to dampen the actual effect of the drugs in Dunyo 2000, but this cannot explain the lack of effect in Simonsen 2004. The dose of ivermectin was also higher in the Haiti study (Beach 1999) than the other two trials. The trials used different techniques to assess mf: investigators in Haiti used the thick film method in $20 \mu \mathrm{L}$ of blood and measurement at night; in both Dunyo 2000 and Simonsen 2004 the counting chamber method in $100 \mu \mathrm{L}$ of blood was used, with measurement during the day (Dunyo 2000) or at night (Simonsen 2004).

Two very small trials in $\mathrm{mf}$ positive individuals and one larger population-based trial compared albendazole with DEC (Fox 2005; Jayakody 1993; Pani 2002). The two small trials found no statistically significant differences in mf prevalence or density at any of the time points measured. Fox 2005 found a statistically significant reduction in $\mathrm{mf}$ prevalence in favour of DEC at six months, but no difference at three months.

Three trials also compared albendazole and DEC with both drugs co-administered. The two small trials from India, Kshirsagar 2004 and Pani 2002, showed no statistically significant differences at any time point up to two years follow up between DEC alone and albendazole plus DEC. Fox 2005 found a reduction in $\mathrm{mf}$ prevalence favouring the combination at six months, but this was not statistically significant. There was no difference between the combination and DEC alone at three months. None of the three trials demonstrated any differences in antigen prevalence between the combination and DEC alone. However, one of the three trials, Fox 2005, did find a statistically significant reduction in geometric mean $\mathrm{mf}$ density at six months in favour of the combination (although there was no statistically significant difference in $\mathrm{mf}$ density at three months or antigen density at six months).

Although all trials provided data on geometric mean mf density, a lack of reporting of standard deviations or confidence intervals from most trials made it impossible to include these results in a meta-analysis. A reduction in $\mathrm{mf}$ geometric mean density was observed for all treatments including placebo, and the reduction appeared greater for active treatments (albendazole, DEC, and ivermectin), but tests of statistical significance were not always carried out or reported. 
The effect of treatment on clinical disease was not remarkable in any of the comparison groups. This is not surprising as effect sizes for clinical outcomes were small and the trials were not powered to detect small clinical benefits.

No serious adverse events were observed in six of the trials (Beach 1999; Dunyo 2000; Fox 2005; Kshirsagar 2004; Pani 2002; Simonsen 2004). Jayakody 1993 found a very high incidence of "scrotal syndrome" among those treated with albendazole, but the doses of both albendazole and DEC were very much higher than in the other trials.

\section{A U THORS, CONCLUSIONS}

\section{Implications for practice}

Based on limited data, the evidence suggests that albendazole when used alone is not better than placebo, ivermectin, or DEC in clearing blood microfilariae. Results from trials that compared albendazole plus ivermectin with ivermectin alone were inconsistent, although two of three showed a reduction in mf density. Two small trials found little difference in albendazole co-administered with DEC compared with DEC alone, but one larger trial tended to favour the combination at six months, with a significant reduction in $\mathrm{mf}$ density. Most trials were underpowered to assess the effects of albendazole, alone or in combination, on morbidity or adverse events. Only larger scale studies can determine if any effect is of practical importance.

The conclusions of this review are based on trials that have randomized and treated individuals, therefore they should be cautiously extrapolated to large-scale, population-based mass drug administration programmes.

\section{Implications for research}

Only limited data were found - further large well-designed trials are required in several areas including:
- the effectiveness of albendazole in combination with DEC or ivermectin on treatment and control of lymphatic filariasis;

- the impact of albendazole in mass drug administration campaigns; and

- studies of other interventions (against the parasite or the vector) to augment mass drug administration.

The complete clearance of blood $\mathrm{mf}$ (or reduction to levels below which transmission is unlikely) theoretically represents the most reliable strategy for interrupting transmission. But this may be difficult to achieve in practice, as ivermectin mainly acts on $\mathrm{mf}$ with no demonstrable macrofilaricidal activity. A drug that kills both $\mathrm{mf}$ and adults would clearly be ideal, and there is an argument for more research and development towards such a drug. Studies of potential macrofilaricides could be assessed objectively, as with ultrasound detection, to directly monitor adult worms. It is also not known how low microfilarial densities need to fall in order to successfully interrupt transmission from the various vector species. As microfilaraemia is an intermediate outcome reflecting infectivity of the human host, it is important to assess comparative effectiveness of drugs that aim to interrupt transmission. Techniques for assessing $\mathrm{mf}$ in blood and outcome measures for $\mathrm{mf}$ densities need to be standardized with complete reporting of geometric means and standard deviations.

\section{ACKNOWLEDGEMENTS}

We would like to thank Leanne Fox and other authors of the Fox 2005 paper for providing us with additional analyses from their trial. The first version of the review was supported by the Lymphatic Filariasis Support Centre, Liverpool School of Tropical Medicine, UK, and GlaxoSmithKline, UK.

This document is an output from a project funded by the UK Department for International Development (DFID) for the benefit of developing countries. The views expressed are not necessarily those of DFID.

\section{R E F E R E N C E S}

\section{References to studies included in this review}

Beach 1999 \{published data only\}

Addiss DG, Beach MJ, Streit TG, Lutwick S, LeConte FH,

Lafontant JG, et al.Randomised placebo-controlled comparison of ivermectin and albendazole alone and in combination for Wuchereria bancrofti microfilaraemia in Haitian children. Lancet 1997;350(9076):480-4.

* Beach MJ, Streit TG, Addiss DG, Prospere R, Roberts JM, Lammie PJ. Assessment of combined ivermectin and albendazole for treatment of intestinal helminth and Wuchereria bancrofti infections in Haitian school children. American Journal of Tropical Medicine and Hygiene 1999;60(3):479-86.

\section{Dunyo 2000 \{published data only\}}

Dunyo SK, Nkrumah FK, Simonsen PE. A randomized doubleblind placebo-controlled field trial of ivermectin and albendazole alone and in combination for the treatment of lymphatic filariasis in Ghana. Transactions of the Royal Society of Tropical Medicine and 
Hygiene 2000;94(2):205-11.

* Dunyo SK, Nkrumah FK, Simonsen PE. Single-dose treatment of Wuchereria bancrofti infections with ivermectin and albendazole alone or in combination: evaluation of the potential for control at 12 months after treatment. Transactions of the Royal Society of Tropical Medicine and Hygiene 2000;94(4):437-43.

Dunyo SK, Simonsen PE. Ivermectin and albendazole alone and in combination for the treatment of lymphatic filariasis. Transactions of the Royal Society for Tropical Medicine and Hygiene 2002;96(2): 189-92.

\section{Fox 2005 \{unpublished data only\}}

Fox LM, Furness BW, Haser JK, Desire D, Brissau JM, Milord $\mathrm{MD}$, et al.Tolerance and efficacy of combined diethylcarbamazine and albendazole for treatment of Wuchereria bancrofti and intestinal helminth infections in Haitian children. American journal of tropical medicine and hygiene 2005;73(1):115-21.

Jayakody 1993 \{published data only\} Jayakody RL, De Silva CS, Weerasinghe WM. Treatment of bancroftian filariasis with albendazole: evaluation of efficacy and adverse reactions. Tropical Biomedicine 1993;10:19-24.

\section{Kshirsagar 2004 \{published data only\}}

Kshirsagar NA, Gogtay NJ, Garg BS, Deshmukh PR, Rajgor DD, Kadam VS, et al.Safety, tolerability, efficacy and plasma concentrations of diethylcarbamazine and albendazole coadministration in a field study in an area endemic for lymphatic filariasis in India. Transactions of the Royal Society of Tropical Medicine and Hygiene 2004;98(4):205-17.

Pani 2002 \{published data only\}

* Pani S, Subramanyam Reddy G, Das L, Vanamail P, Hoti S, Ramesh J, et al.Tolerability and efficacy of single dose albendazole, diethylcarbamazine citrate (DEC) or co-administration of albendazole with DEC in the clearance of Wuchereria bancrofti in asymptomatic microfilaraemic volunteers in Pondicherry, South India: a hospital-based study. Filaria Journal 2002;1(1):1. Pani SP, Reddy SR, Das LK, Vanamail P. Efficacy of single dose albendazole, diethylcarbamazine citrare (DEC) or coadministration of both in clearance of Wuchereria bancrofti microfilarial and adult parasites in asymptomatic microfilaraemic volunteers: Results of two-year follow-up. Indian Journal of Lymphology 2004;2:20-3.

Simonsen 2004 \{unpublished data only\} Simonsen PE, Magesa SM, Dunyo SK, Malecela-Lazaro MN, Michael E. The effect of single dose ivermectin alone or in combination with albendazole on Wuchereria bancrofti infection in primary school children in Tanzania. Transactions of the Royal Soceity of Tropical Medicine and Hygiene 2004;98(8):462-72.

\section{References to studies excluded from this review}

\section{Dunyo 2002 \{published data only\}}

Dunyo SK, Simonsen PE. Ivermectin and albendazole alone and in combination for the treatment of lymphatic filariasis in Ghana: follow-up after re-treatment with the combination.. Transaction of the Royal Society of Tropical Medicine and Hygiene 2002;96(2): 189-92.

\section{Ismail 1998 \{published data only\}}

Dunyo SK, Simonsen PE. Ivermectin and albendazole alone and in combination for the treatment of lymphatic filariasis in Ghana: follow-up after re-treatment with the combination.. Transactions of the Royal Society Tropical Medicine and Hygiene 2002;96(2):189-92. Ismail MM, Jayakody RL, Weil GJ, Fernando D, De Silva MS, De Silva GA, et al.Long-term efficacy of single-dose combinations of albendazole, ivermectin and diethylcarbamazine for the treatment of bancroftian filariasis. Transactions of the Royal Society of Tropical Medicine and Hygiene 2001;95(3):332-5.

Ismail MM, Jayakody RL, Weil GJ, Nirmalan N, Jayasinghe KS, Abeyewickrema W, et al.Efficacy of single dose combinations of albendazole, ivermectin and diethylcarbamazine for the treatment of bancroftian filariasis. Transactions of the Royal Society of Tropical Medicine and Hygiene 1998;92(1):94-7.

\section{Makunde 2003 \{published data only\}}

Makunde WH, Kamugisha LM, Massaga JJ, Makunde RW, Savael ZX, Akida J, et al.Treatment of co-infection with bancroftian filariasis and onchocerciasis: a safety and efficacy study of albendazole with ivermectin compared to treatment of single infection with bancroftian filariasis. Filaria Journal 2003;2(1):15.

Shenoy 1999 \{published data only\}

* Shenoy RK, Dalia S, John A, Suma TK, Kumaraswami V. Treatment of the microfilaraemia of asymptomatic brugian filariasis with single doses of ivermectin, diethylcarbamazine or albendazole, in various combinations. Annals of Tropical Medicine and Parasitology 1999;93(6):643-51.

Shenoy RK, John A, Babu BS, Suma TK, Kumaraswami V. Twoyear follow-up of the microfilaraemia of asymptomatic brugian filariasis, after treatment with two, annual, single doses of ivermectin, diethylcarbamazine and albendazole, in various combinations. Annals of Tropical Medicine and Parasitology 2000;94 (6):607-14.

Shenoy 2002 \{published data only\}

Shenoy RK, Suma TK, John A, Arun SR, Kumaraswami V, Fleckenstein LL, et al.The pharmacokinetics, safety and tolerability of the co-administration of diethylcarbamine and albendazole. Annals of Tropical Medicine and Parasitology 2002;96(6):603-14.

\section{References to ongoing studies}

Dahoma (ongoing) \{published data only (unpublished sought but not used)\}

Dahoma, et al.Assessment of safety and efficacy of ivermectin and albendazole co-administration.

\section{Additional references}

\section{Addiss 2000}

Addiss D, Dreyer G. Treatment of lymphatic filariasis. In: Nutman BT editor(s). Lymphatic filariasis. London: Imperial College Press, 2000:151-99.

\section{Andrade 1995}

Andrade LD, Medeiros Z, Pires ML, Pimentel A, Rocha A, Figueredo-Silva J, et al.Comparative efficacy of three different diethylcarbamazine regimens in lymphatic filariasis. Transactions of the Royal Society of Tropical Medicine and Hygiene 1995;89(3): 319-21. 
Barat 1997

Barat LM, Bloland PB. Drug resistance among malaria and other parasites. Infectious Disease Clinics of North America 1997;11(4): 969-87.

\section{Basanez 1994}

Basanez MG, Boussinesq M, Prod'hon J, Frontado H, Villamizar NJ, Medley GF, et al.Density-dependent processes in the transmission of human onchocerciasis: intensity of microfilariae in theskin and their uptake by the simuliid host. Parasitology 1994; 108(Pt 1):115-27.

\section{Burkot 2002}

Burkot TR, Taleo G, Toeaso V, Ichimori K. Progress towards, and challenges for, the elimination of filariasis from Pacific-island communities. Annals of Tropical Medicine and Parasitology 2002;96 Suppl 2:61-9.

\section{Cao 1997}

Cao WC, Van der Ploeg CP, Plaisier AP, van der Sluijs IJ, Habbema JD. Ivermectin for the chemotherapy of bancroftian filariasis: a meta-analysis of the effect of single treatment. Tropical Medicine and International Health 1997;2(4):393-403.

\section{Cartel 1990}

Cartel JL, Sechan Y, Boutin JP, Celerier P, Plichart R, Roux JF. Ivermectin for treatement of bancroftian filariasis French Polynesia: efficacy in man, effect on transmission by vector Aedes polynesiensis. Tropical Medicine and Parasitology 1990;41(3): $241-4$.

\section{CDS/FIL 1998}

Filariasis Elimination Programme (CDS/FIL). Division of Control of Tropical Diseases, Communicable Diseases. Report from informal consultation on albendazole research findings in lymphatic filariasis; WHO/FIL/98.194; (closed document). Geneva: World Health Organization, 1998.

\section{Coutinho 1994}

Coutinho AD, Dreyer G, Medeiros Z, Lopes E, Machado G, Galdino E, et al.Ivermectin treatment of bancroftian filariasis in Recife, Brazil. American Journal of Tropical Medicine and Hygiene 1994;50(3):339-48.

\section{Dreyer 1994}

Dreyer G, Pires ML, Andrade LD, Lopes E, Medeiros Z, Tenorio J, et al. Tolerance of diethylcarbamazine by microfilaraemic and amicrofilaraemic individuals in an endemic area of Bancroftian filariasis, Recife, Brazil. Transactions of the Royal Society of Tropical Medicine Hygiene 1994;88(2):232-6.

\section{Dreyer 1995}

Dreyer G, Amaral F, Noroes J, Medeiros Z, Addiss D. A new tool to assess in vivo the adulticidal efficacy of antifilarial drugs for bancroftian filariasis. Transactions of the Royal Society of Tropical Medicine and Hygiene 1995;89(2):225-6.

\section{Dreyer 1996}

Dreyer G, Addiss D, Noroes J, Amaral F, Rocha A, Coutinho A. Ultrasonographic assessment of the adulticidal efficacy of repeat high-dose ivermectin in bancroftian filariasis. Tropical Medicine and International Health 1996;1(4):427-32.

\section{Dreyer 2000}

Dreyer G, Noroes J, Figueredo-Silva J, Piessens WF. Pathogenesis of lymphatic disease in bancroftian filariasis: a clinical perspective. Parasitology Today 2000;16(12):544-8.

\section{Eberhard 1989}

Eberhard ML, Lammie PJ, Roberts JM, Lowrie RC Jr. Effectiveness of spaced doses of diethylcarbamazine citrate for the control of bancroftian filariasis. Tropical Medicine and Parasitology 1989;40 (2):111-3.

\section{FGN 1996}

The Filarial Genome Network. Biology and epidemiology of filarial nematodes. http://www.math.smith.edu/ -sawlab/fgn/pnb/ filbio.html 1996 (accessed 3 September 2001).

\section{Figueredo-Silva 1996}

Figueredo-Silva J, Jungmann P, Noroes J, Piessens WF, Coutinho A, Brito C, et al.Histological evidence for adulticidal effect of low doses of diethylcarbamazine in bancroftian filariasis. Transactions of the Royal Society of Tropical Medicine and Hygiene 1996;90(2):192-4.

\section{Geerts 2001}

Geerts S, Gryseels B. Anthelmintic resistance in human helminths: a review. Tropical Medicine and International Health 2001;6(11): 915-21.

\section{Gelband 1994}

Gelband H. Diethylcarbamazine salt in the control of lymphatic filariasis. American Journal of Tropical Medicine 1994;50(6):655-62.

\section{GlaxoSmithKline 2003}

GlaxoSmithKline. Lymphatic filariasis programme: eliminating lymphatic filariasis. www.gsk.com/filariasis/eliminating.htm (accessed October 2002).

\section{Gyapong 2005}

Gyapong JO, Kumaraswami V, Biswas G, Ottesen EA. Treatment strategies underpinning the global programme to eliminate lymphatic filariasis. Expert Opinion on Pharmacotherapy 2005;6(2): $179-200$.

\section{Higgins 2005}

Higgins J, Green S, editors. Highly sensitive search strategies for identifying reports of randomized controlled trials in MEDLINE. Cochrane Handbook for Systematic Reviews of Interventions 4.2.5 [updated May 2005]; Appendix 5b. http://www.cochrane.org/ resources/handbook/hbook.htm (accessed 11 August 2005).

\section{Horton 2000}

Horton J. Albendazole: a review of anthelmintic efficacy and safety in humans. Parasitology 2000;121 Suppl:113-32.

\section{Jüni 2001}

Jüni P, Altman DG, Egger M. Systematic reviews in health care: Assessing the quality of controlled clinical trials. BMJ 2001;323 (7303):42-6.

\section{Mahoney 1971}

Mahoney LE, Kessel JF. Treatment failure in filariasis mass treatment programmes. Bulletin of the World Health Organization 1971;45(1):35-42.

\section{Meyrowitsch 1995}

Meyrowitsch DW, Simonsen PE, Makunde WH. A 16-year followup study on bancroftian filariasis in three communities of north- 
eastern Tanzania. Annals of Tropical Medicine and Parasitology 1995; 89(6):665-75.

\section{Michael 1996}

Michael E, Bundy DA, Grenfell BT. Re-assessing the global prevalence and distribution of lymphatic filariasis. Parasitology 1996;112(Pt 4):409-28.

\section{NCI 1999}

National Cancer Institute. Common Toxicity Criteria Manual. ctep.cancer.gov/forms/CTCManual_v4_10-4-99.pdf (accessed 9 June 2005).

\section{Noroes 1997}

Noroes J, Dreyer G, Santos A, Mendes VG, Medeiros Z, Addiss D. Assessment of the efficacy of diethylcarbamazine on adult Wuchereria bancrofti in vivo. Transactions of the Royal Society Tropical Medicine and Hygiene 1997;9(1):78-81.

\section{Ottesen 1997}

Ottesen EA, Duke BO, Karam M, Behbehani K. Strategies and tools for the control/elimination of lymphatic filariasis. Bulletin of the World Health Organization 1997;75(6):491-503.

\section{Ottesen 1999}

Ottesen EA, Ismail MM, Horton J. The role of albendazole in programmes to eliminate lymphatic filariasis. Parasitology Today 1999; 15(9):382-6.

Pichon 2002

Pichon G. Limitation and facilitation in the vectors and other aspects of the dynamics of filarial transmission: the need for vector control against Anopheles-transmitted filariasis. Annals of Tropical Medicine and Parasitology 2002;96 Suppl 2:143-52.

\section{Review Manager 5}

The Nordic Cochrane Centre, The Cochrane Collaboration. Review Manager (RevMan). 5.0. Copenhagen: The Nordic Cochrane Centre, The Cochrane Collaboration, 2008.

\section{Scott 2000}

Scott AL. Lymphatic-dwelling filariae. In: Nutman BT editor(s). Lymphatic filariasis. London: Imperial College Press, 2000:5-39.

\section{Simonsen 1995}

Simonsen PE, Meyrowitsch DW, Makunde WH, Magnussen P. Selective diethylcarbamazine chemotherapy for control of Bancroftian filariasis in two communities of Tanzania: compared efficacy of a standard dose treatment and two semi-annual single dose treatments. American Journal of Tropical Medicine and Hygiene 1995;53(3):267-72.

\section{Simonsen 1997}

Simonsen PE, Niemann L, Meyrowitsch DW. Wuchereria bancrofti in Tanzania: microfilarial periodicity and effect of blood sampling time on microfilarial intensities. Tropical Medicine and International Health 1997;2(2):153-8.

\section{Taylor 2001}

Taylor MJ, Cross HF, Ford L, Makunde WH, Prasad GB, Bilo K. Wolbachia bacteria in filarial immunity and disease. Parasite immunology 2001;23(7):401-9.

\section{Vanamail 1990}

Vanamail P, Subramanian S, Das PK, Pani SP, Rajagopalan PK. Estimation of fecundic life span of Wuchereria bancrofti from longitudinal study of human infection in an endemic area of Pondicherry (south India). Indian Journal of Medical Research 1990; 91:293-7.

\section{Weil 1997}

Weil GJ, Lammie PJ, Weiss N. The ICT Filariasis Test: A rapidformat antigen test for diagnosis of bancroftian filariasis. Parasitology Today 1997;13(10):401-4.

\section{Weil 1999}

Weil GJ, Ramzy RM, El Setouhy M, Kandil AM, Ahmed ES, Faris R. A longitudinal study of Bancroftian filariasis in the Nile Delta of Egypt: baseline data and one-year follow-up. American Journal of Tropical Medicine and Hygiene 1999;61(1):53-8.

\section{WHO 1984}

WHO Expert Committee on Filariasis. Lymphatic filariasis: fourth report of the WHO Expert Committee on Filariasis [meeting held in Geneva from 31 October to 8 November 1983]; Technical Report Series no. 702. Geneva: World Health Organization, 1984.

\section{WHO 2000}

World Health Organization Office of Information. Lymphatic filariasis; WHO fact sheet no. 102. Geneva: World Health Organization, 1996.

\section{References to other published versions of this review}

\section{Critchley in press}

Critchley J, Addiss D, Ejere H, Gamble C, Garner P, Gelband H. Albendazole for the control and elimination of lymphatic filariasis: systematic review. Tropical Medicine and International Health 2005; 10(9):818-25.

\section{IFRG 2004}

International Filariasis Review Group (David Addiss, Julia Critchley, Henry Ejere, Paul Garner, Hellen Gelband, Carrol Gamble). Albendazole for lymphatic filariasis. Cochrane Database of Systematic Reviews 2004, Issue 1. [DOI: 10.1002/ 14651858.CD003753.pub2]

* Indicates the major publication for the study 
CHARACTERISTICS OF STUDIES

\section{Characteristics of included studies [ordered by study ID]}

\section{Beach 1999}

\begin{tabular}{ll} 
Methods & $\begin{array}{l}\text { Individually randomized controlled trial } \\
\text { Generation of allocation sequence: random-number table } \\
\text { Allocation concealment: concealed by third party } \\
\text { Blinding: "Double blind" stated, although drugs were not identical, patients had no way of identifying them; outcome } \\
\text { assessors blinded } \\
\text { Inclusion of all randomized participants in the analysis: } 585 \text { analysed of } 965 \text { randomized (61\%) } \\
\text { Length of follow up: } 4 \text { months } \\
\text { Method of microfilariae (mf) assessment/volume of blood: thick smear; } 20 \mu \mathrm{L} \text { of finger-prick blood }\end{array}$ \\
\hline Participants & $\begin{array}{l}\text { Number randomized: } 965, \text { of whom } 113 \text { were mf positive } \\
\text { Children (male and female) aged } 5 \text { to } 11 \text { years with Wuchereria bancrofti filariasis }\end{array}$ \\
\hline Interventions & $\begin{array}{l}\text { 1. Albendazole: } 400 \mathrm{mg}, 244 \text { participants } \\
\text { 2. Ivermectin: } 200 \text { to } 400 \mu \text { /kg, } 240 \text { participants } \\
\text { 3. Albendazole plus ivermectin: doses as above, } 245 \text { participants } \\
\text { 4. Placebo: } 229 \text { participants }\end{array}$ \\
\hline Outcomes & $\begin{array}{l}\text { 1. Post-treatment reduction in } \% \text { mf prevalence } \\
\text { 2. \% reduction in geometric mean mf density (Note: standard deviation not reported; no values reported for the } \\
\text { albendazole group) }\end{array}$ \\
$\begin{array}{l}\text { 3. Prevalence of W. bancrofti among all children in each treatment group } \\
\text { 4. Frequency of the occurrence of specific systemic adverse events, such as fever, headache, weakness, muscle/joint } \\
\text { pain, itching, rash, abdominal pain, and diarrhoea }\end{array}$ \\
\hline Notes
\end{tabular}

\section{Dunyo 2000}

Methods Individually randomized controlled trial
Generation of allocation sequence: computer generated
Allocation concealment: concealed by third party
Blinding: identical placebos used for each group
Inclusion of all randomized participants in the analysis: 273 analysed of 340 microfilariae (mf) positive randomized
$(80 \%)$
Length of follow up: 12 months
Method of mf assessment/volume of blood: $\mathrm{mf}$ in $100 \mu \mathrm{L}$ of finger-prick blood using the counting chamber technique,
daytime collection
Antigen testing: ELISA from finger-prick blood specimens

Participants Number randomized: 1425, of whom $340 \mathrm{mf}$ positive were followed up Individuals (male and female) aged 6 to 87 years with or without Wuchereria bancrofti 
Dunyo 2000 (Continued)

\author{
Interventions 1. Albendazole: $400 \mathrm{mg}, 88$ participants \\ 2. Ivermectin: 150 to $200 \mu \mathrm{g} / \mathrm{kg}$, 79 participants \\ 3. Albendazole plus ivermectin: doses as above, 90 participants \\ 4. Placebo: 83 participants
}
Outcomes 1. Number of individuals $\mathrm{mf}$ positive at 12 months post-treatment
2. Geometric mean $\mathrm{mf}$ density (Note: standard deviation not reported)
3. $\%$ of pretreatment $\mathrm{mf}$ concentration
4. Geometric mean circulating filarial antigen (CFA) density
5. Geometric mean CFA density as $\%$ of pretreatment value
6. New infections (appearance of antigenaemia)
7. New disease events (lymphoedema or hydrocoele)
8. Mortality during follow up
9. Frequency of specific systemic adverse events as well as the number of individuals presenting with any adverse event post-treatment; reactions graded as $0=$ none, $1=$ mild (noticeable to patient but not interfering with daily activities), 2 = moderate (some interference with daily activities), 3 = severe (complete interruption of daily activities) (Note: Adjusted and unadjusted $\mathrm{mf}$ geometric mean $\mathrm{mf}$ intensities given)

Notes Location: southern Ghana (Butre, Achowa, Adjan, and Miamia villages)

Endemicity level: $18 \%$ to $25 \%$

\title{
Fox 2005
}

Methods Individually randomized controlled trial

Generation of allocation sequence: random number table

Allocation concealment: unclear

Blinding: "Double blind" stated, although no dummy procedure; in reality, only outcome assessors likely to be 'blind' Inclusion of all randomized participants in the analysis: 990 of $1292(76 \%)$ analysed

Length of follow up: 6 months

Method of microfilariae (mf) assessment/volume of blood: $20 \mu \mathrm{L}$ thick smear between 7:30 and 9:30 pm

Antigen testing: $\mathrm{Og} 4 \mathrm{C} 3$ assay for circulating filarial antigen (CFA)

Participants Number randomized: 990

Children aged 5 to 11 years attending any of 12 selected primary schools

Interventions 1. Albendazole alone: $400 \mathrm{mg}, 256$ participants

2. Diethylcarbamazine (DEC) alone: $6 \mathrm{mg} / \mathrm{kg}$ body weight, 246 participants

3. Placebo: 243 participants

4. DEC and albendazole: doses as above, 245 participants

Outcomes

1. \% of children in each group who had no $\mathrm{mf}$ detected in blood 3 and 6 months post-treatment

2. Mean $\%$ reduction in $\mathrm{mf}$ density 3 and 6 months post-treatment

3. Geometric mean \% reduction in mf density 3 and 6 months post-treatment

4. CFA: $\%$ of children with negative CFA 6 months post-treatment

5. Mean $\%$ reduction in CFA density, geometric mean

6. \% reduction in CFA density 6 months after treatment

7. Adverse events: assessed every day for $7 \mathrm{~d}$ after treatment by blinded clinicians who questioned and examined children at school; adverse events recorded were self-reported or documented fever, headache, myalgias, and cough; 


\section{Fox 2005 (Continued)}

also reported a mean treatment impact score by day for the first seven days ( 1 = symptoms noticed, but did not interfere with daily activities, 2 = symptoms caused some interference with daily activities, $3=$ symptoms prevented usual daily activities)

(Note: standard deviations for geometric mean density changes reported on request)

Notes Location: Leogane commune, Haiti

Endemicity level: $14.7 \%$ of children had $\mathrm{mf}$ and $31.4 \%$ were positive CFA at baseline

\section{Jayakody 1993}

\begin{tabular}{ll} 
Methods & $\begin{array}{l}\text { Individually randomized controlled trial } \\
\text { Generation of allocation sequence: pre-determined randomization list } \\
\text { Allocation concealment: states randomization list 'restricted' } \\
\text { Blinding: unclear } \\
\text { Inclusion of all randomized participants in the analysis: } 20 \text { analysed of } 29 \text { randomized (74\%) } \\
\text { Length of follow up: } 19 \text { months } \\
\text { Method of microfilariae (mf) assessment/volume of blood: membrane filtration for using a Nucleopore filter (3 } \mu \mathrm{m} \\
\text { pore size) }\end{array}$ \\
\hline Participants & $\begin{array}{l}\text { Number randomized: } 29 \\
\text { Asymptomatic men aged } 18 \text { to } 65 \text { with Wuchereria bancrofti mf } \\
\text { Patients with mf density in night blood films }>100 \mathrm{mf} / \mathrm{mL} \text { at least once during previous week included }\end{array}$ \\
\hline Interventions & $\begin{array}{l}\text { 1. Albendazole: } 400 \mathrm{mg} \text { given twice daily for } 21 \mathrm{~d}, 16 \text { participants } \\
\text { 2. Diethylcarbamazine (DEC): } 6 \mathrm{mg} / \mathrm{kg} \text { daily for } 21 \mathrm{~d}, 13 \text { participants }\end{array}$ \\
\hline Outcomes & $\begin{array}{l}\text { 1. Post-treatment } \% \text { prevalence reduction } \\
\text { 2. \% reduction in geometric mean mf density } \\
\text { 3. Adverse events: the prevalence and severity of "scrotal syndrome" (pain in the scrotum, enlargement of epididymis, } \\
\text { and some systemic features, such as fever, thought to be caused by death of adult worms) during the treatment period }\end{array}$ \\
\hline Notes & $\begin{array}{l}\text { Location: Colombo, Sri Lanka } \\
\text { Endemicity level: not stated }\end{array}$ \\
\hline
\end{tabular}


Kshirsagar 2004

\begin{tabular}{|c|c|}
\hline Methods & $\begin{array}{l}\text { Individually randomized controlled trial } \\
\text { Generation of allocation sequence: states randomized, exact details unclear } \\
\text { Allocation concealment: unclear } \\
\text { Blinding: used identical placebos and double dummy procedure } \\
\text { Inclusion of all randomized participants in the analysis: } 1395 / 1403(99 \%) \text { analysed in safety study; } 103 \text { microfilariae } \\
\text { (mf)-positive men were selected for the efficacy study, but follow up of these was adequate at some time points but } \\
\text { inadequate at others } \\
\text { Length of follow up: } 12 \text { months } \\
\text { Method of mf assessment/volume of blood: thick smear, } 60 \mu \mathrm{L} \text { of finger-prick blood or venepuncture between } 9 \text { and } \\
11 \text { pm } \\
\text { Antigen testing: immunochromatographic card } \\
\text { Detection of adult filarial worm by USG machine; all regions of scrotum and spermatic cord systematically studied, } \\
\text { and "filaria dance sign" identified }\end{array}$ \\
\hline Participants & $\begin{array}{l}\text { Number: } 1403 \text { randomized for safety study; } 103 \text { for efficacy assessment } \\
\text { Safety study: males and females over } 5 \text { years old with and without Wuchereria bancrofti } \\
\text { Efficacy assessment: males aged } 18 \text { to } 50\end{array}$ \\
\hline Interventions & $\begin{array}{l}\text { 1. Diethylcarbamazine (DEC): } 6 \mathrm{mg} / \mathrm{kg} \text { body weight and albendazole } 400 \mathrm{mg} \\
\text { 2. DEC plus albendazole-placebo }\end{array}$ \\
\hline Outcomes & $\begin{array}{l}\text { 1. Number mf positive at 3, 6, and } 12 \text { months (and \% of pretreatment levels) } \\
\text { 2. Number immunochromatographic card test (ICT) positive at } 3,6 \text {, and } 12 \text { months (and \% pretreatment levels) } \\
\text { 3. Number ultrasonography USG positive at } 3,6 \text {, and } 12 \text { months (and } \% \text { pretreatment levels); results stratified } \\
\text { for those mf positive at baseline ( } 43 \text { participants), with clinical disease ( } 30 \text { participants), and mf negative and } \\
\text { asymptomatic ( } 30 \text { participants) } \\
\text { 4. Adverse events: total incidence and number of participants with adverse drug reactions on days } 2 \text { or } 5 \text {, number of } \\
\text { early terminations, number of participants where adverse events interfered with daily activities, and global assessment } \\
\text { of tolerability (very good or good, satisfactory, poor or insufficient, not assessable). Also categorized the severity of } \\
\text { adverse reactions according to the National Cancer Institute Common Toxicity Criteria (NCI 1999) }\end{array}$ \\
\hline Notes & $\begin{array}{l}\text { Location: } 2 \text { endemic villages in Wardha, Maharashtra (Western India) } \\
\text { Endemicity level: } 7.27 \% \text { in } 1995 \\
\text { Efficacy data: at many time points there were no men with clinical disease or mf negative at baseline surveyed }\end{array}$ \\
\hline
\end{tabular}




\begin{tabular}{|c|c|}
\hline Methods & $\begin{array}{l}\text { Individually randomized controlled trial } \\
\text { Generation of allocation sequence: unclear } \\
\text { Allocation concealment: adequate - coding of drugs performed by independent monitor } \\
\text { Blinding: comparable placebo and outcome assessors 'blind' } \\
\text { Inclusion of all randomized participants in the analysis: implies no losses to follow up ( } 54 \text { analysed out of } 54 \\
\text { randomized) } \\
\text { Length of follow up: } 24 \text { months } \\
\text { Method of microfilariae (mf) assessment/volume of blood: not clear, } 1 \mathrm{~mL} \text { venous blood collected between } 7: 30 \text { to } \\
\text { 8:30 pm } \\
\text { Antigen testing: immunochromatographic card test and by Og4C3 ELISA test kit on } 50 \mu \mathrm{L} \text { serum }\end{array}$ \\
\hline Participants & $\begin{array}{l}\text { Number randomized: } 54 \\
\text { Asymptomatic volunteers (male and female) between } 10 \text { and } 57 \text { years old who were mf positive }\end{array}$ \\
\hline Interventions & $\begin{array}{l}\text { 1. Albendazole: } 400 \mathrm{mg}, 19 \text { participants } \\
\text { 2. Diethylcarbamazine (DEC): } 6 \mathrm{mg} / \mathrm{kg}, 17 \text { participants } \\
\text { 3. Albendazole plus DEC: doses as above, } 18 \text { participants }\end{array}$ \\
\hline Outcomes & $\begin{array}{l}\text { 1. } \% \text { of individuals } \mathrm{mf} \text { positive post-treatment } \\
\text { 2. \% reduction in geometric mean } \mathrm{mf} \\
\text { 3. \% reduction in filarial antigen prevalence } \\
\text { 4. Adverse events: monitored all participants in hospital for adverse reactions at } 8 \text {-h intervals for the first } 24 \mathrm{~h} \text {, then } \\
\text { every } 24 \mathrm{~h} \text { for a further } 3 \mathrm{~d} \text {; proportion of individuals reporting any systemic adverse event and intensity (using a } \\
\text { simple scoring system) of adverse events were noted } \\
\text { (Note: no standard deviation reported for geometric mean mf density) }\end{array}$ \\
\hline Notes & $\begin{array}{l}\text { Location: Pondicherry, India } \\
\text { Endemicity level: not given in report }\end{array}$ \\
\hline
\end{tabular}

\section{Simonsen 2004}

Methods Individually randomized controlled trial

Generation of allocation sequence: computer generated

Allocation concealment: concealed by third party

Blinding: used identical placebos and double dummy procedure

Inclusion of all randomized participants in the analysis: 1221 of $1829(67 \%)$ analysed

Length of follow up: 12 months

Method of microfilariae (mf) assessment/volume of blood: $100 \mu \mathrm{L}$ finger-prick blood, counting chamber technique

Antigen testing: circulating filarial antigen (CFA) on TropBio filter paper collection discs; blood sampling for mf and

CFA started at $9 \mathrm{pm}$

Participants Number randomized: 1829, of which 1221 (67\%) followed up; 103 had $\mathrm{mf}$

School children aged 6 to 18 years with or without Wuchereria bancrofti

Interventions 1. Albendazole plus ivermectin: $400 \mathrm{mg}$ albendazole, 150 to $200 \mu \mathrm{g} / \mathrm{kg}$ ivermectin, 586 participants

2. Ivermectin alone: dose as above, 635 participants 


$\begin{array}{ll}\text { Outcomes } & \text { Results reported only in } 103 \text { mf-positive participants at baseline } \\ \text { 1. Number of individuals mf positive at } 6 \text { and } 12 \text { months post-treatment } \\ \text { 2. Geometric mean mf concentration and \% of pretreatment geometric means at } 6 \text { and } 12 \text { months } \\ \text { 3. Number of children CFA positive at } 6 \text { and } 12 \text { months and \% of pretreatment CFA } \\ \text { 4. Geometric mean density CFA and \% of pretreatment CFA geometric mean density } \\ \text { 5. New cases of mf positivity amongst those mf negative at baseline } \\ \text { 6. New cases of CFA positivity amongst those CFA negative at baseline } \\ \text { 7. Adverse reactions: children followed for } 5 \mathrm{~d} \text { after treatment by passive observation; specific adverse reactions, } \\ \text { such as headache, fever, joint pain, diarrhoea, dizziness, vomiting and itching noted, but number of events in each } \\ \text { treatment group not clearly reported } \\ \text { (Note: standard deviation not reported for geometric mean mf density) }\end{array}$

\section{Characteristics of excluded studies [ordered by study ID]}

\begin{tabular}{ll}
\hline Study & Reason for exclusion \\
\hline Dunyo 2002 & $\begin{array}{l}\text { Update of Dunyo } 2000 \text { following retreatment of each treatment group; retreatment carried out only with the } \\
\text { combination (ALB plus IV), hence no comparison group given IV alone }\end{array}$ \\
\hline Ismail 1998 & $\begin{array}{l}\text { The comparison groups - ALB versus ALB plus IV versus ALB plus DEC versus DEC plus IV - do not match } \\
\text { those in the review; these comparisons do not provide answers to the question as to whether adding ALB to IV } \\
\text { or DEC improves outcomes compared to IV or DEC alone; the comparisons would have to include IV alone or } \\
\text { DEC alone as comparators to be relevant to the review }\end{array}$ \\
\hline Makunde 2003 & $\begin{array}{l}\text { Comparison groups do not match those in review; for single infections with Wuchereria bancrofti these were ALB } \\
\text { plus IV versus ALB alone; for co-infections of W. bancrofti and Onchocerca volvulus these were IV plus ALB versus } \\
\text { placebo }\end{array}$ \\
\hline Shenoy 1999 & $\begin{array}{l}\text { The comparison groups - ALB versus ALB plus IV versus ALB plus DEC versus DEC plus IV - do not match those } \\
\text { in the review; excluded for reasons stated above for Ismail 1998 }\end{array}$ \\
\hline Shenoy 2002 & $\begin{array}{l}\text { Study of safety and tolerability of adding ALB to DEC; carried out only in patients without microfilariaemia (ie } \\
\text { presumably uninfected) }\end{array}$ \\
\hline
\end{tabular}

ALB: albendazole; DEC: diethylcarbamazine; IV: ivermectin. 


\section{Characteristics of ongoing studies [ordered by study ID]}

\section{Dahoma (ongoing)}

\begin{tabular}{ll}
\hline Trial name or title & Assessment of safety and efficacy of ivermectin and albendazole co-administration \\
\hline Methods & - \\
\hline Participants & $\begin{array}{l}1000 \text { participants living in an area endemic for lymphatic filariasis and soil transmitted helminths in Zanzibar, } \\
\text { Tanzania }\end{array}$ \\
\hline Interventions & $\begin{array}{l}\text { 1. Ivermectin } \\
\text { 2. Albendazole plus ivermectin }\end{array}$ \\
\hline Outcomes & $\begin{array}{l}\text { 1. Reappearance of microfilariae at } 12 \text { months } \\
\text { 2. Microfilariae at } 3 \text { and } 6 \text { months } \\
\text { 3. Adverse drug reactions }\end{array}$ \\
\hline Starting date & - \\
\hline Contact information & $\begin{array}{l}\text { Mark Bradley } \\
\text { SmithKline Beecham } \\
\text { GlaxoWellcome House West } \\
\text { Berkeley Avenue } \\
\text { Greenford } \\
\text { Middlesex UB6 } 0 \text { NN } \\
\text { UK } \\
\text { Phone: }+442089668543 \\
\text { Fax: }+44208966887 \\
\text { Email: mhb38319@GlaxoWellcome.co.uk }\end{array}$ \\
\hline -
\end{tabular}

The names of principal investigator is used as the study ID. 
DATA AND ANALYSES

Comparison 1. Albendazole versus placebo

\begin{tabular}{|c|c|c|c|c|}
\hline Outcome or subgroup title & $\begin{array}{l}\text { No. of } \\
\text { studies }\end{array}$ & $\begin{array}{c}\text { No. of } \\
\text { participants }\end{array}$ & Statistical method & Effect size \\
\hline $\begin{array}{l}1 \text { Microfilariae }(\mathrm{mf}) \text { prevalence: all } \\
\text { participants (both mf positive } \\
\text { or negative at baseline) }\end{array}$ & 2 & & Risk Ratio (M-H, Fixed, 95\% CI) & Subtotals only \\
\hline 1.1 At 3 to 4 months & 2 & 783 & Risk Ratio (M-H, Fixed, 95\% CI) & $0.95[0.66,1.37]$ \\
\hline 1.2 At 6 months & 1 & 499 & Risk Ratio (M-H, Fixed, 95\% CI) & $1.00[0.66,1.53]$ \\
\hline $\begin{array}{l}2 \text { Microfilariae }(\mathrm{mf}) \text { prevalence: } \\
\text { only participants } \mathrm{mf} \text { positive at } \\
\text { baseline }\end{array}$ & 2 & 195 & Risk Ratio (M-H, Fixed, 95\% CI) & $0.97[0.87,1.09]$ \\
\hline $\begin{array}{l}3 \text { Antigen prevalence: all } \\
\text { participants (both mf positive } \\
\text { or negative at baseline) }\end{array}$ & 2 & 1090 & Risk Ratio (M-H, Fixed, 95\% CI) & $0.95[0.81,1.12]$ \\
\hline 4 New clinical disease & 1 & & Risk Ratio (M-H, Fixed, 95\% CI) & Totals not selected \\
\hline 4.1 Hydrocoele & 1 & & Risk Ratio (M-H, Fixed, 95\% CI) & Not estimable \\
\hline 5 Pre-existing clinical disease & 1 & & Risk Ratio (M-H, Fixed, 95\% CI) & Totals not selected \\
\hline $\begin{array}{l}5.1 \text { Improvement in } \\
\text { lymphoedema }\end{array}$ & 1 & & Risk Ratio (M-H, Fixed, 95\% CI) & Not estimable \\
\hline $\begin{array}{l}5.2 \text { Improvement in } \\
\text { hydrocoele }\end{array}$ & 1 & & Risk Ratio (M-H, Fixed, 95\% CI) & Not estimable \\
\hline 6 Adverse events & 1 & & Risk Ratio (M-H, Fixed, 95\% CI) & Totals not selected \\
\hline 6.1 Systemic & 1 & & Risk Ratio (M-H, Fixed, 95\% CI) & Not estimable \\
\hline
\end{tabular}

\section{Comparison 2. Albendazole versus ivermectin}

\begin{tabular}{|c|c|c|c|c|}
\hline Outcome or subgroup title & $\begin{array}{l}\text { No. of } \\
\text { studies }\end{array}$ & $\begin{array}{c}\text { No. of } \\
\text { participants }\end{array}$ & Statistical method & Effect size \\
\hline $\begin{array}{l}\text { Microfilariae }(\mathrm{mf}) \text { prevalence: all } \\
\text { participants (both mf positive } \\
\text { or negative at baseline) }\end{array}$ & 1 & & Risk Ratio (M-H, Fixed, 95\% CI) & Totals not selected \\
\hline $\begin{array}{l}2 \text { Microfilariae }(\mathrm{mf}) \text { prevalence: } \\
\text { only participants } \mathrm{mf} \text { positive at } \\
\text { baseline }\end{array}$ & 2 & 198 & Risk Ratio (M-H, Fixed, 95\% CI) & $0.84[0.72,0.98]$ \\
\hline $\begin{array}{l}3 \text { Antigen prevalence: all } \\
\text { participants (antigen positive } \\
\text { or negative at baseline) }\end{array}$ & 1 & & Risk Ratio (M-H, Fixed, 95\% CI) & Totals not selected \\
\hline 4 New clinical disease & 1 & & Risk Ratio (M-H, Fixed, 95\% CI) & Totals not selected \\
\hline 4.1 Hydrocoele & 1 & & Risk Ratio (M-H, Fixed, 95\% CI) & Not estimable \\
\hline 5 Pre-existing clinical disease & 1 & & Risk Ratio (M-H, Fixed, 95\% CI) & Totals not selected \\
\hline $\begin{array}{l}5.1 \text { Improvement in } \\
\text { lymphoedema }\end{array}$ & 1 & & Risk Ratio (M-H, Fixed, 95\% CI) & Not estimable \\
\hline
\end{tabular}

Albendazole for lymphatic filariasis (Review)

Copyright (C) 2009 The Cochrane Collaboration. Published by John Wiley \& Sons, Ltd. 


\begin{tabular}{llll}
$\begin{array}{l}\text { 5.2 Improvement in } \\
\text { hydrocoele }\end{array}$ & 1 & Risk Ratio (M-H, Fixed, 95\% CI) & Not estimable \\
6 Adverse events & 1 & Risk Ratio (M-H, Fixed, 95\% CI) & Totals not selected \\
6.1 Systemic & 1 & Risk Ratio (M-H, Fixed, 95\% CI) & Not estimable \\
\hline
\end{tabular}

Comparison 3. Albendazole plus ivermectin versus ivermectin

\begin{tabular}{|c|c|c|c|c|}
\hline Outcome or subgroup title & $\begin{array}{l}\text { No. of } \\
\text { studies }\end{array}$ & $\begin{array}{c}\text { No. of } \\
\text { participants }\end{array}$ & Statistical method & Effect size \\
\hline $\begin{array}{l}1 \text { Microfilariae (mf) prevalence: all } \\
\text { participants (both mf positive } \\
\text { or negative at baseline) }\end{array}$ & 1 & & Risk Ratio (M-H, Fixed, 95\% CI) & Totals not selected \\
\hline $\begin{array}{l}2 \text { Microfilariae }(\mathrm{mf}) \text { prevalence: } \\
\text { only participants mf positive at } \\
\text { baseline }\end{array}$ & 3 & & Risk Ratio (M-H, Random, 95\% CI) & Subtotals only \\
\hline 2.1 At 4 to 6 months & 2 & 255 & Risk Ratio (M-H, Random, 95\% CI) & $0.49[0.18,1.39]$ \\
\hline 2.2 At 12 months & 2 & 348 & Risk Ratio (M-H, Random, 95\% CI) & $1.00[0.88,1.13]$ \\
\hline $\begin{array}{l}3 \text { Antigen prevalence: all } \\
\text { participants (antigen positive } \\
\text { or negative) at baseline }\end{array}$ & 1 & & Risk Ratio (M-H, Fixed, 95\% CI) & Totals not selected \\
\hline $\begin{array}{l}4 \text { Antigen prevalence: only } \\
\text { participants antigen positive at } \\
\text { baseline }\end{array}$ & 2 & & Risk Ratio (M-H, Fixed, 95\% CI) & Totals not selected \\
\hline 4.1 Data at 6 months & 1 & & Risk Ratio (M-H, Fixed, 95\% CI) & Not estimable \\
\hline 4.2 Data at 12 months & 2 & & Risk Ratio (M-H, Fixed, 95\% CI) & Not estimable \\
\hline $5 \mathrm{New}$ clinical disease & 1 & & Risk Ratio (M-H, Fixed, 95\% CI) & Totals not selected \\
\hline 5.1 Hydrocoele & 1 & & Risk Ratio (M-H, Fixed, 95\% CI) & Not estimable \\
\hline 6 Pre-existing clinical disease & 1 & & Risk Ratio (M-H, Fixed, 95\% CI) & Totals not selected \\
\hline $\begin{array}{l}6.1 \text { Improvement in } \\
\text { lymphoedema }\end{array}$ & 1 & & Risk Ratio (M-H, Fixed, 95\% CI) & Not estimable \\
\hline $\begin{array}{l}6.2 \text { Improvement in } \\
\text { hydrocoele }\end{array}$ & 1 & & Risk Ratio (M-H, Fixed, 95\% CI) & Not estimable \\
\hline 7 Adverse events & 2 & & Risk Ratio (M-H, Fixed, 95\% CI) & Totals not selected \\
\hline 7.1 Total & 1 & & Risk Ratio (M-H, Fixed, 95\% CI) & Not estimable \\
\hline 7.2 Systemic & 1 & & Risk Ratio (M-H, Fixed, 95\% CI) & Not estimable \\
\hline
\end{tabular}

Comparison 4. Albendazole versus diethylcarbamazine (DEC)

\begin{tabular}{|c|c|c|c|c|}
\hline Outcome or subgroup title & $\begin{array}{l}\text { No. of } \\
\text { studies }\end{array}$ & $\begin{array}{c}\text { No. of } \\
\text { participants }\end{array}$ & Statistical method & Effect size \\
\hline $\begin{array}{l}1 \text { Microfiliariae }(\mathrm{mf}) \text { prevalence: } \\
\text { all participants (both } \mathrm{mf} \\
\text { positive or negative at baseline) }\end{array}$ & 1 & & Risk Ratio (M-H, Fixed, 95\% CI) & Totals not selected \\
\hline 1.1 At 3 months & 1 & & Risk Ratio (M-H, Fixed, 95\% CI) & Not estimable \\
\hline 1.2 At 6 months & 1 & & Risk Ratio (M-H, Fixed, 95\% CI) & Not estimable \\
\hline
\end{tabular}


2 Microfilariae $(\mathrm{mf})$ prevalence:
only participants $\mathrm{mf}$ positive at

baseline

\subsection{After 3 months}

2.2 After 1 year

2.3 After 2 years

3 Antigen prevalence: all participants (both antigen positive or negative at baseline)

4 Antigen prevalence: only participants antigen positive at baseline

4.1 ICT test

5 Adverse events

6 Adverse events: scrotal syndrome
Risk Ratio (M-H, Fixed, 95\% CI)

Subtotals only

$0.95[0.82,1.10]$

$1.19[0.57,2.49]$

$3.58[0.44,28.97]$

Totals not selected

Risk Ratio (M-H, Fixed, 95\% CI)

Totals not selected

Risk Ratio (M-H, Fixed, 95\% CI)

Risk Ratio (M-H, Fixed, 95\% CI)

Risk Ratio (M-H, Fixed, 95\% CI)
Not estimable

Totals not selected

Totals not selected

Comparison 5. Albendazole plus diethylcarbamazine (DEC) versus DEC

\begin{tabular}{|c|c|c|c|c|}
\hline Outcome or subgroup title & $\begin{array}{l}\text { No. of } \\
\text { studies }\end{array}$ & $\begin{array}{c}\text { No. of } \\
\text { participants }\end{array}$ & Statistical method & Effect size \\
\hline $\begin{array}{l}1 \text { Microfilariae }(\mathrm{mf}) \text { prevalence: all } \\
\text { participants (both mf positive } \\
\text { or negative at baseline) }\end{array}$ & 1 & & Risk Ratio (M-H, Fixed, 95\% CI) & Totals not selected \\
\hline 1.1 At 3 months & 1 & & Risk Ratio (M-H, Fixed, 95\% CI) & Not estimable \\
\hline 1.2 At 6 months & 1 & & Risk Ratio (M-H, Fixed, 95\% CI) & Not estimable \\
\hline $\begin{array}{l}2 \text { Microfilariae }(\mathrm{mf}) \text { prevalence: } \\
\text { only participants mf positive at } \\
\text { baseline }\end{array}$ & 2 & & Risk Ratio (M-H, Fixed, 95\% CI) & Subtotals only \\
\hline 2.1 At 3 months & 2 & 73 & Risk Ratio (M-H, Fixed, 95\% CI) & $1.06[0.83,1.36]$ \\
\hline 2.2 At 6 months & 1 & 42 & Risk Ratio (M-H, Fixed, 95\% CI) & $1.0[0.62,1.61]$ \\
\hline 2.3 At 12 months & 2 & 78 & Risk Ratio (M-H, Fixed, 95\% CI) & $0.99[0.69,1.44]$ \\
\hline 2.4 At 2 years & 1 & 35 & Risk Ratio (M-H, Fixed, 95\% CI) & $0.94[0.06,13.93]$ \\
\hline $\begin{array}{l}3 \text { Antigen prevalence: all } \\
\text { participants (both antigen } \\
\text { positive and negative at } \\
\text { baseline) }\end{array}$ & 2 & & Risk Ratio (M-H, Fixed, 95\% CI) & Subtotals only \\
\hline 3.1 Data at 6 months & 2 & 592 & Risk Ratio (M-H, Fixed, 95\% CI) & $1.00[0.82,1.24]$ \\
\hline 3.2 Data at 12 months & 1 & 103 & Risk Ratio (M-H, Fixed, 95\% CI) & $0.95[0.69,1.31]$ \\
\hline $\begin{array}{l}4 \text { Antigen prevalence: only } \\
\text { participants antigen positive at } \\
\text { baseline }\end{array}$ & 1 & & Risk Ratio (M-H, Fixed, 95\% CI) & Totals not selected \\
\hline 5 Adverse events & 2 & & Risk Ratio (M-H, Fixed, 95\% CI) & Subtotals only \\
\hline 5.1 Any & 2 & 1430 & Risk Ratio (M-H, Fixed, 95\% CI) & $0.88[0.71,1.08]$ \\
\hline $\begin{array}{l}5.2 \text { Interfered with daily } \\
\text { activities }\end{array}$ & 1 & 1395 & Risk Ratio (M-H, Fixed, 95\% CI) & $1.06[0.64,1.73]$ \\
\hline
\end{tabular}


Analysis I.I. Comparison I Albendazole versus placebo, Outcome I Microfilariae (mf) prevalence: all participants (both $\mathrm{mf}$ positive or negative at baseline).

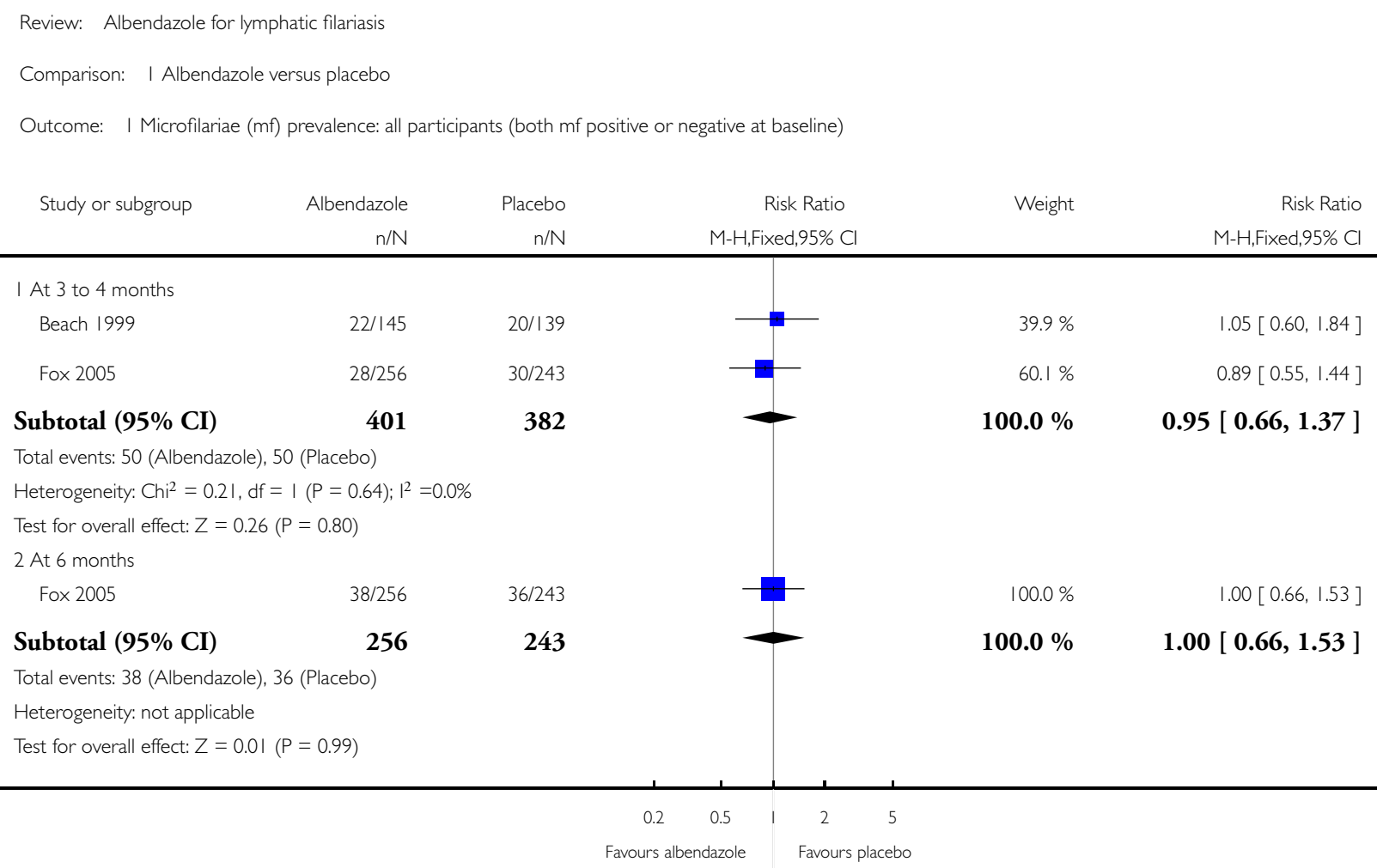


Analysis 1.2. Comparison I Albendazole versus placebo, Outcome 2 Microfilariae (mf) prevalence: only participants $\mathrm{mf}$ positive at baseline.

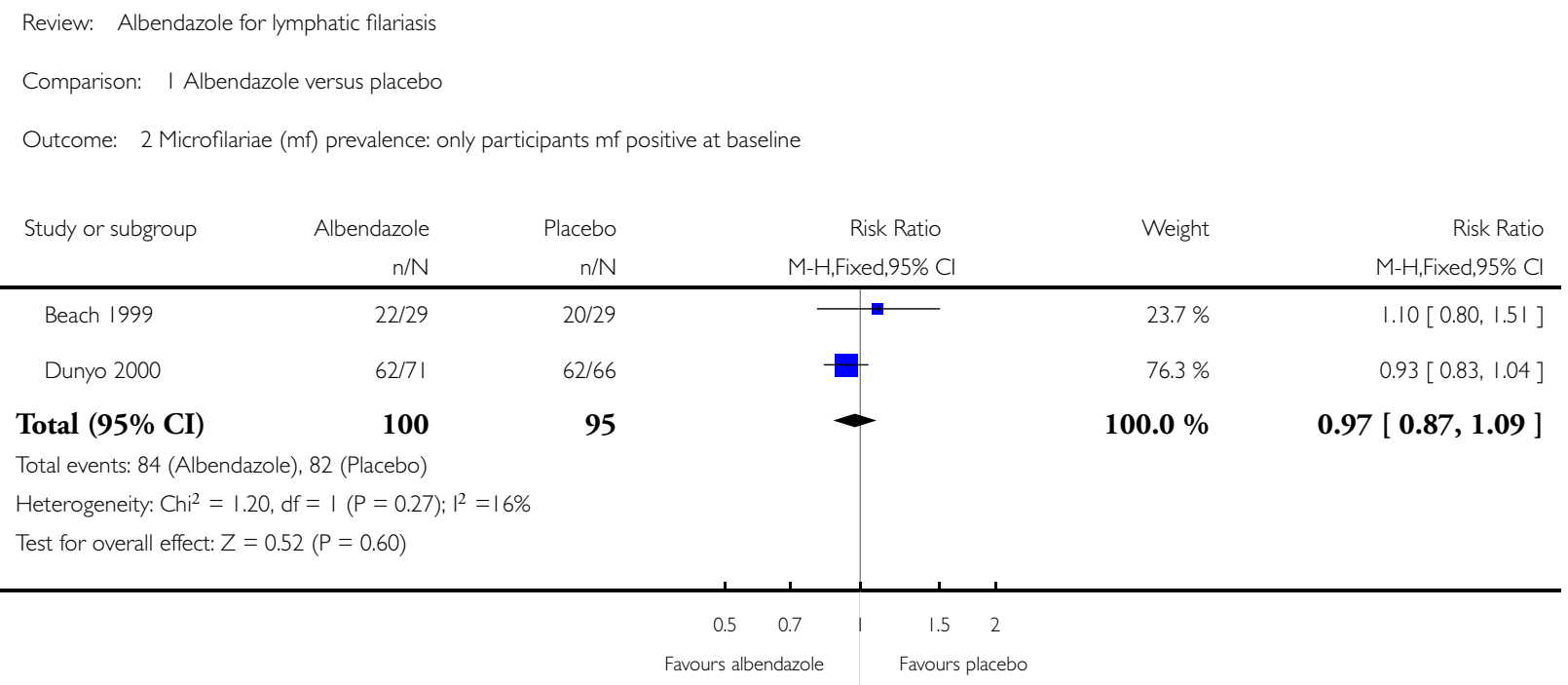

Analysis I.3. Comparison I Albendazole versus placebo, Outcome 3 Antigen prevalence: all participants (both $\mathrm{mf}$ positive or negative at baseline).

Review: Albendazole for lymphatic filariasis

Comparison: I Albendazole versus placebo

Outcome: 3 Antigen prevalence: all participants (both $\mathrm{mf}$ positive or negative at baseline)

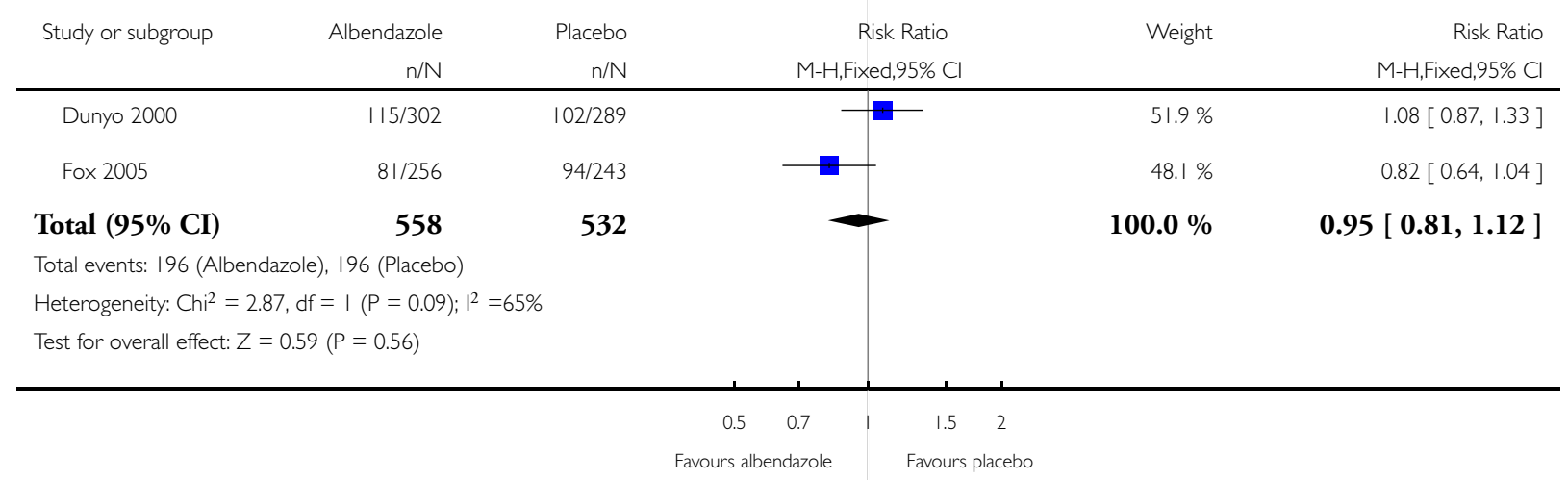


Analysis I.4. Comparison I Albendazole versus placebo, Outcome $4 \mathrm{New}$ clinical disease.

Review: Albendazole for lymphatic filariasis

Comparison: I Albendazole versus placebo

Outcome: 4 New clinical disease

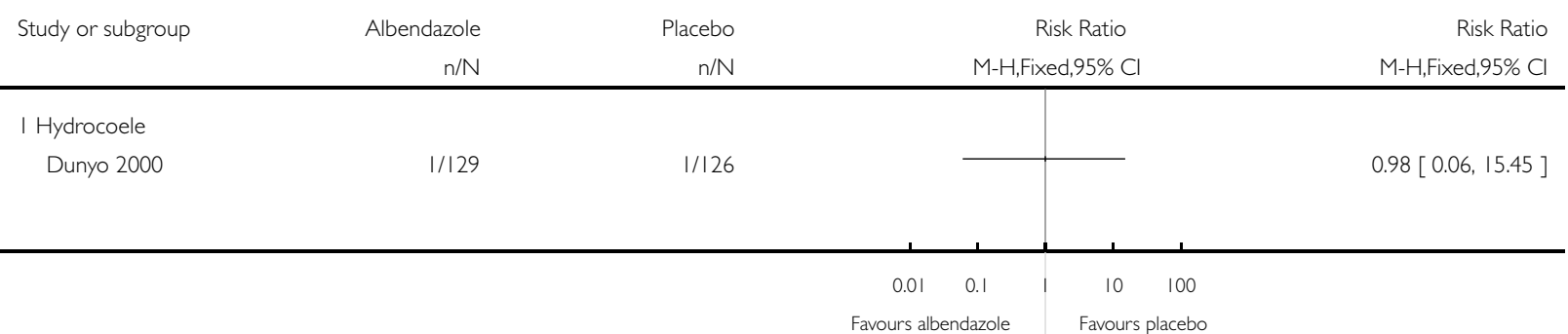

Analysis I.5. Comparison I Albendazole versus placebo, Outcome 5 Pre-existing clinical disease.

Review: Albendazole for lymphatic filariasis

Comparison: I Albendazole versus placebo

Outcome: 5 Pre-existing clinical disease

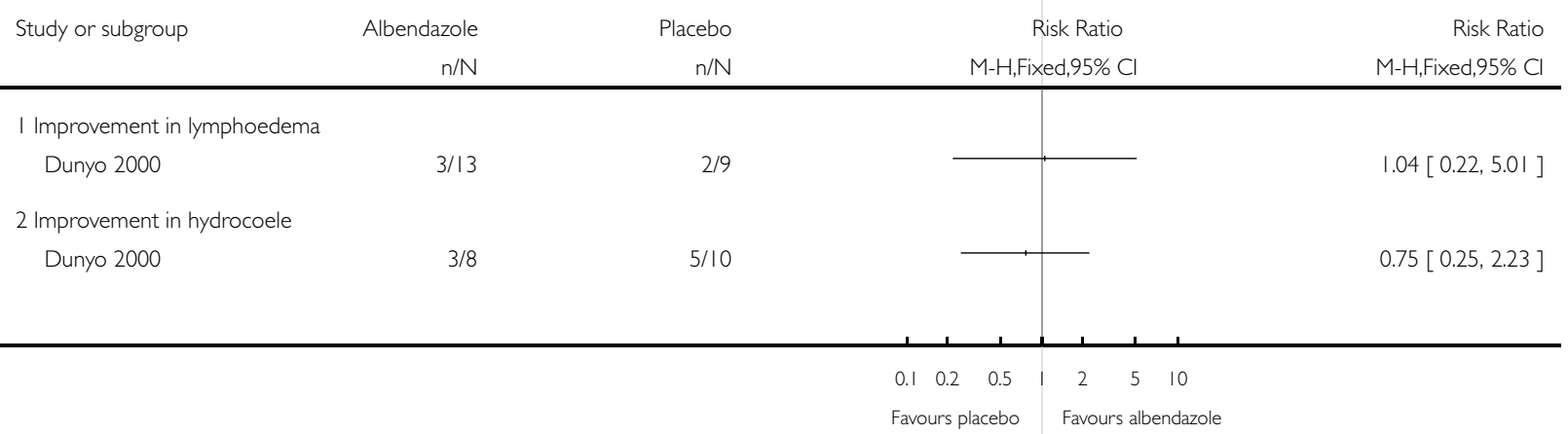


Analysis I.6. Comparison I Albendazole versus placebo, Outcome 6 Adverse events.

Review: Albendazole for lymphatic filariasis

Comparison: I Albendazole versus placebo

Outcome: 6 Adverse events

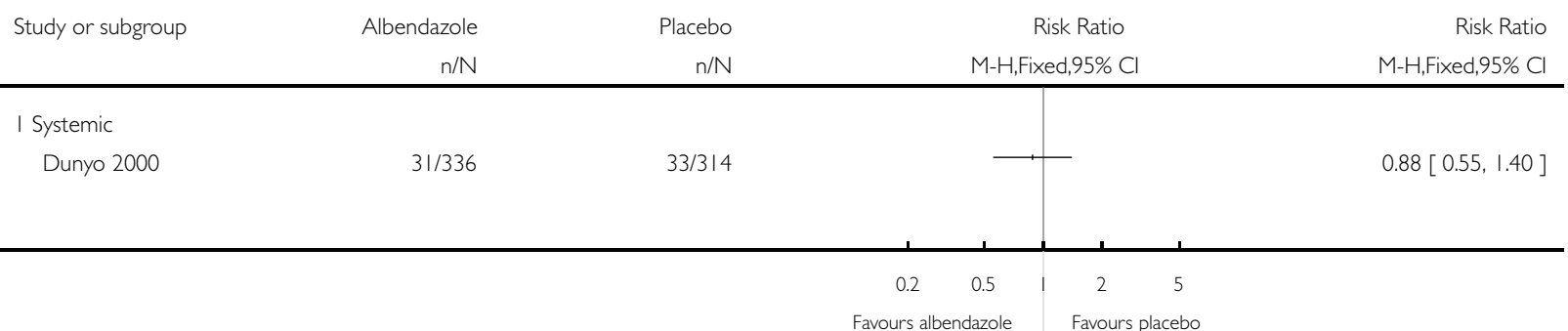

Analysis 2.I. Comparison 2 Albendazole versus ivermectin, Outcome I Microfilariae (mf) prevalence: all participants (both $\mathrm{mf}$ positive or negative at baseline).

Review: Albendazole for lymphatic filariasis

Comparison: 2 Albendazole versus ivermectin

Outcome: I Microfilariae ( $\mathrm{mf}$ ) prevalence: all participants (both $\mathrm{mf}$ positive or negative at baseline)

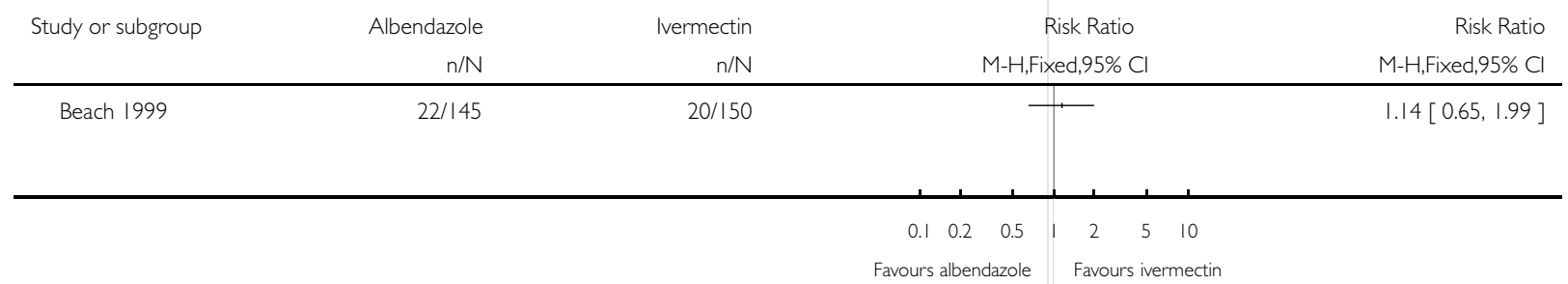


Analysis 2.2. Comparison 2 Albendazole versus ivermectin, Outcome 2 Microfilariae (mf) prevalence: only participants $\mathrm{mf}$ positive at baseline.

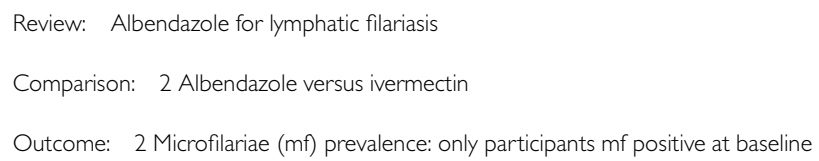

\begin{tabular}{|c|c|c|c|c|c|}
\hline \multirow[t]{2}{*}{ Study or subgroup } & Ivermectin & Albendazole & Risk Ratio & \multirow[t]{2}{*}{ Weight } & \multirow{2}{*}{$\begin{array}{r}\text { Risk Ratio } \\
\text { M-H,Fixed,95\% Cl }\end{array}$} \\
\hline & $n / N$ & $n / N$ & M-H,Fixed,95\% Cl & & \\
\hline Beach 1999 & $17 / 28$ & $22 / 29$ & \begin{tabular}{l|l}
$\mathbf{Q}$ & \\
$\mathbf{P}$
\end{tabular} & $26.0 \%$ & $0.80[0.56,1.15]$ \\
\hline Dunyo 2000 & $52 / 70$ & $62 / 71$ & & $74.0 \%$ & $0.85[0.72,1.00]$ \\
\hline Total (95\% CI) & 98 & 100 & & $0.0 \%$ & {$[0.72,0.98]$} \\
\hline
\end{tabular}

Total $(95 \%$ CI $)$

Total events: 69 (Ivermectin), 84 (Albendazole)

Heterogeneity: $\mathrm{Chi}^{2}=0.10, \mathrm{df}=1(\mathrm{P}=0.76) ; \mathrm{I}^{2}=0.0 \%$

Test for overall effect: $Z=2.27(P=0.023)$

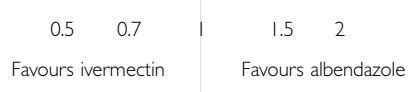

Analysis 2.3. Comparison 2 Albendazole versus ivermectin, Outcome 3 Antigen prevalence: all participants (antigen positive or negative at baseline).

Review: Albendazole for lymphatic filariasis

Comparison: 2 Albendazole versus ivermectin

Outcome: 3 Antigen prevalence: all participants (antigen positive or negative at baseline)

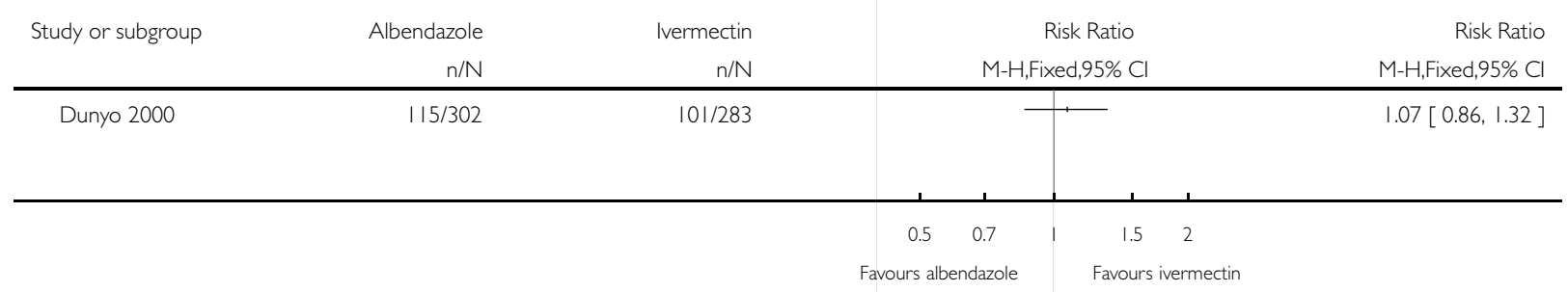


Analysis 2.4. Comparison 2 Albendazole versus ivermectin, Outcome 4 New clinical disease.

Review: Albendazole for lymphatic filariasis

Comparison: 2 Albendazole versus ivermectin

Outcome: 4 New clinical disease

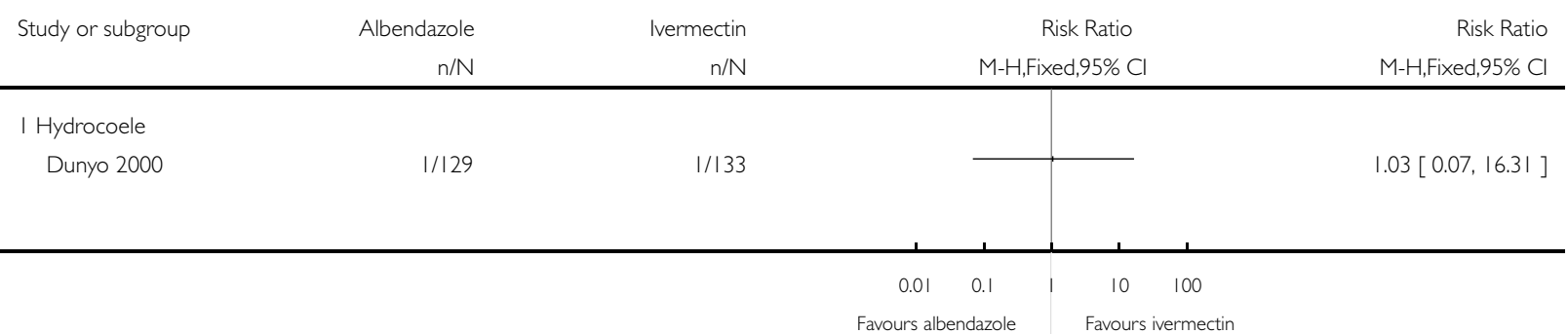

Analysis 2.5. Comparison 2 Albendazole versus ivermectin, Outcome 5 Pre-existing clinical disease.

Review: Albendazole for lymphatic filariasis

Comparison: 2 Albendazole versus ivermectin

Outcome: 5 Pre-existing clinical disease

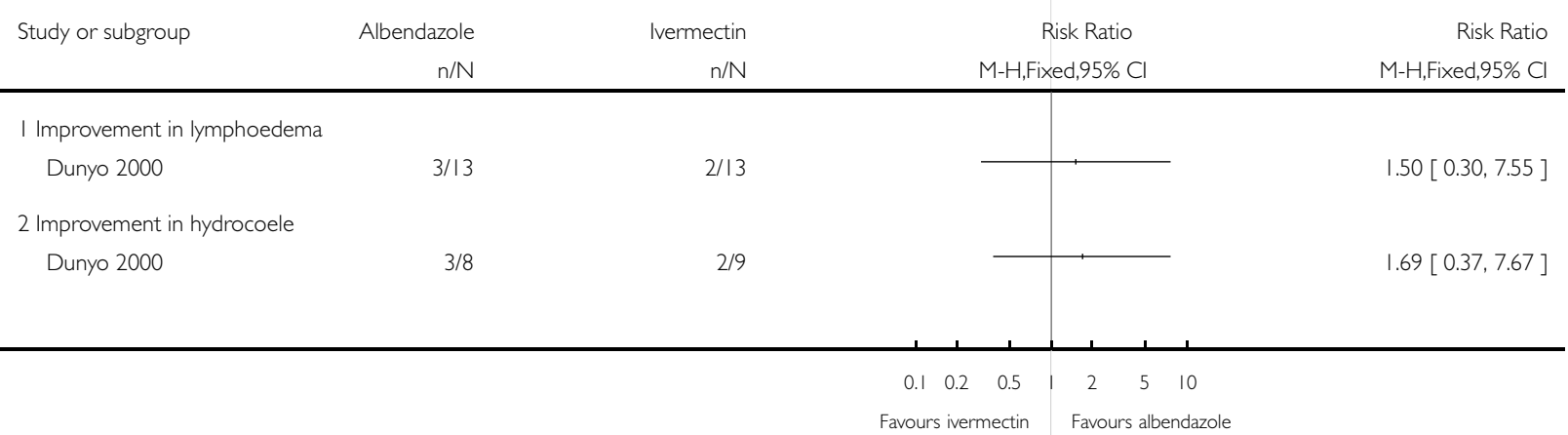


Analysis 2.6. Comparison 2 Albendazole versus ivermectin, Outcome 6 Adverse events.

Review: Albendazole for lymphatic filariasis

Comparison: 2 Albendazole versus ivermectin

Outcome: 6 Adverse events

\begin{tabular}{|c|c|c|c|c|c|c|}
\hline Study or subgroup & Albendazole & Ivermectin & \multicolumn{3}{|c|}{ Risk Ratio } & Risk Ratio \\
\hline \multicolumn{7}{|l|}{ I Systemic } \\
\hline Dunyo 2000 & $31 / 336$ & $36 / 295$ & & & & $0.76[0.48,1.19]$ \\
\hline
\end{tabular}

Analysis 3.I. Comparison 3 Albendazole plus ivermectin versus ivermectin, Outcome I Microfilariae (mf) prevalence: all participants (both $\mathrm{mf}$ positive or negative at baseline).

Review: Albendazole for lymphatic filariasis

Comparison: 3 Albendazole plus ivermectin versus ivermectin

Outcome: I Microfilariae ( $\mathrm{mf}$ ) prevalence: all participants (both $\mathrm{mf}$ positive or negative at baseline)

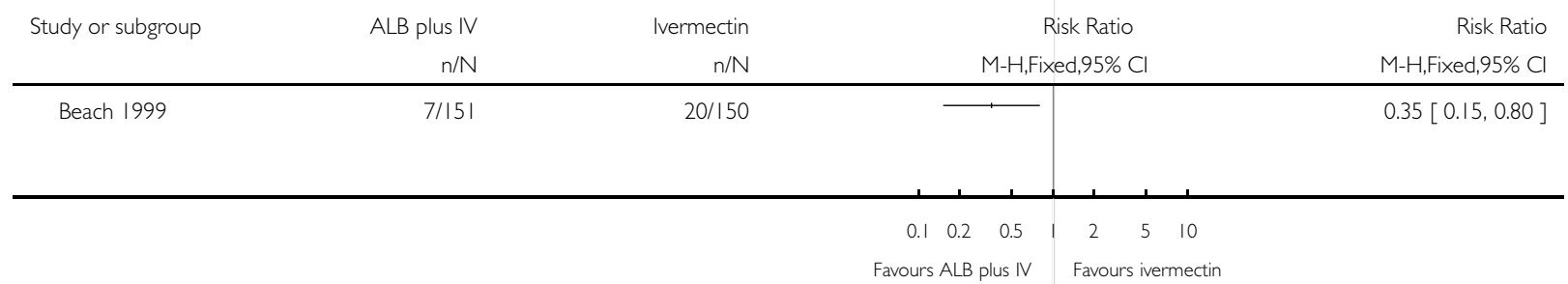


Analysis 3.2. Comparison 3 Albendazole plus ivermectin versus ivermectin, Outcome 2 Microfilariae (mf) prevalence: only participants $\mathrm{mf}$ positive at baseline.

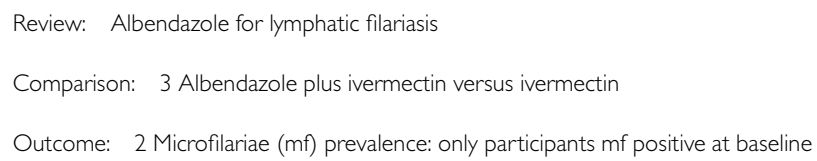

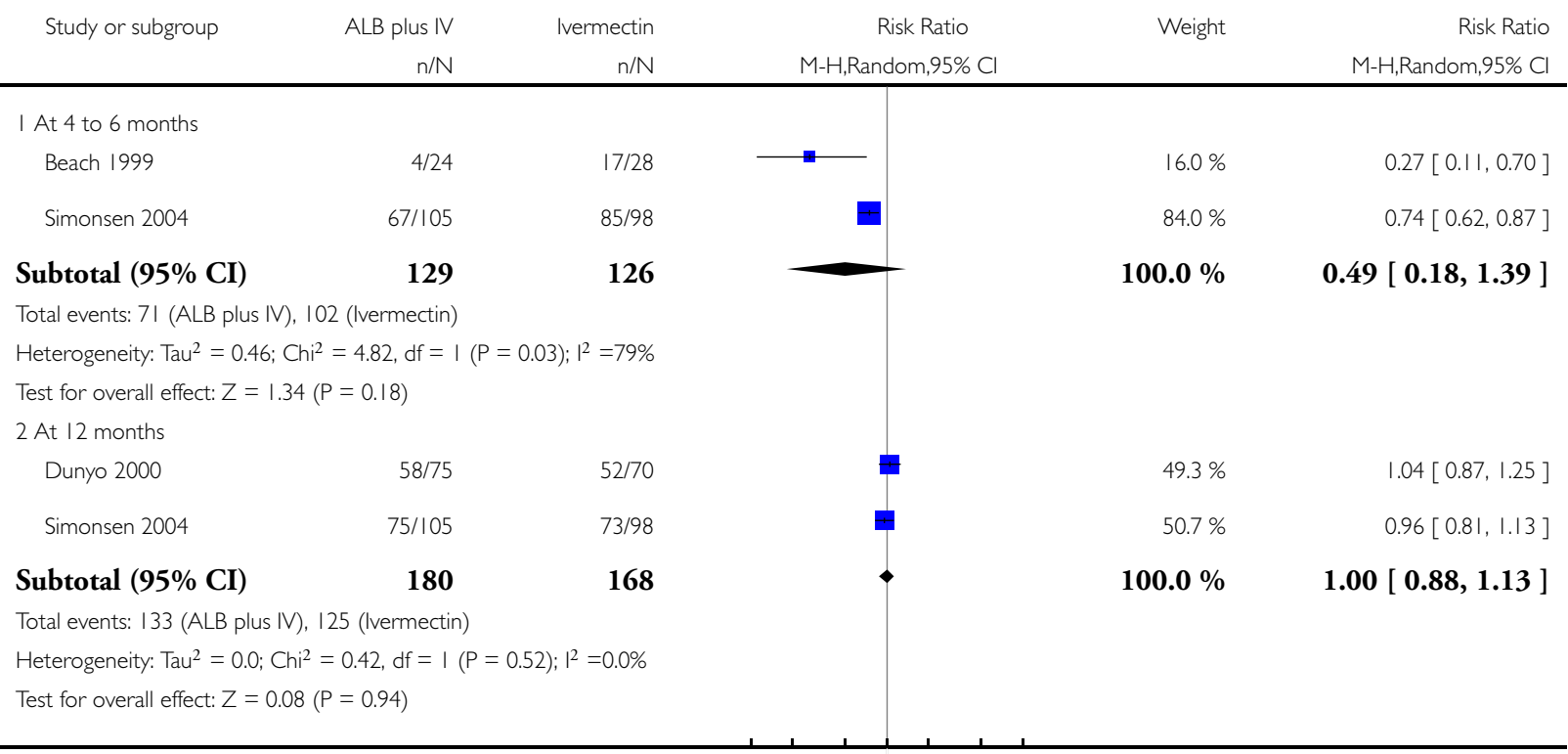

$\begin{array}{lllllll}0.1 & 0.2 & 0.5 & 1 & 2 & 5 & 10\end{array}$

Favours ALB plus IV Favours ivermectin

Analysis 3.3. Comparison 3 Albendazole plus ivermectin versus ivermectin, Outcome 3 Antigen prevalence: all participants (antigen positive or negative) at baseline.

Review: Albendazole for lymphatic filariasis

Comparison: 3 Albendazole plus ivermectin versus ivermectin

Outcome: 3 Antigen prevalence: all participants (antigen positive or negative) at baseline

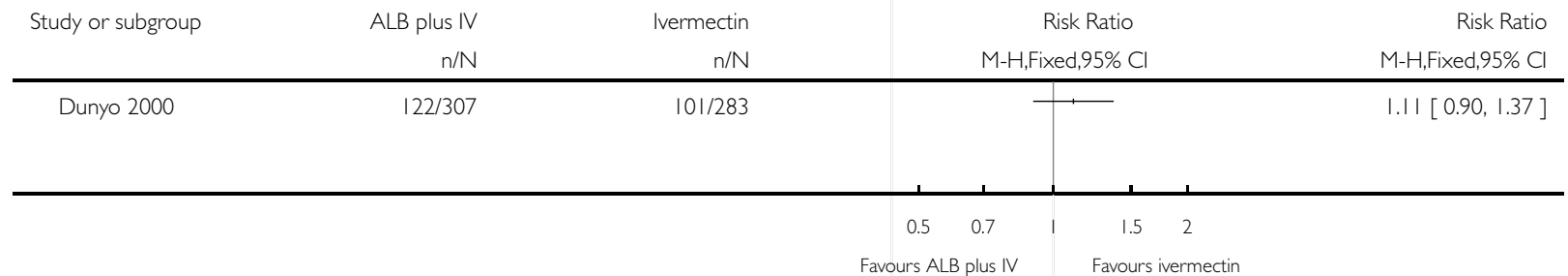


Analysis 3.4. Comparison 3 Albendazole plus ivermectin versus ivermectin, Outcome 4 Antigen prevalence: only participants antigen positive at baseline.

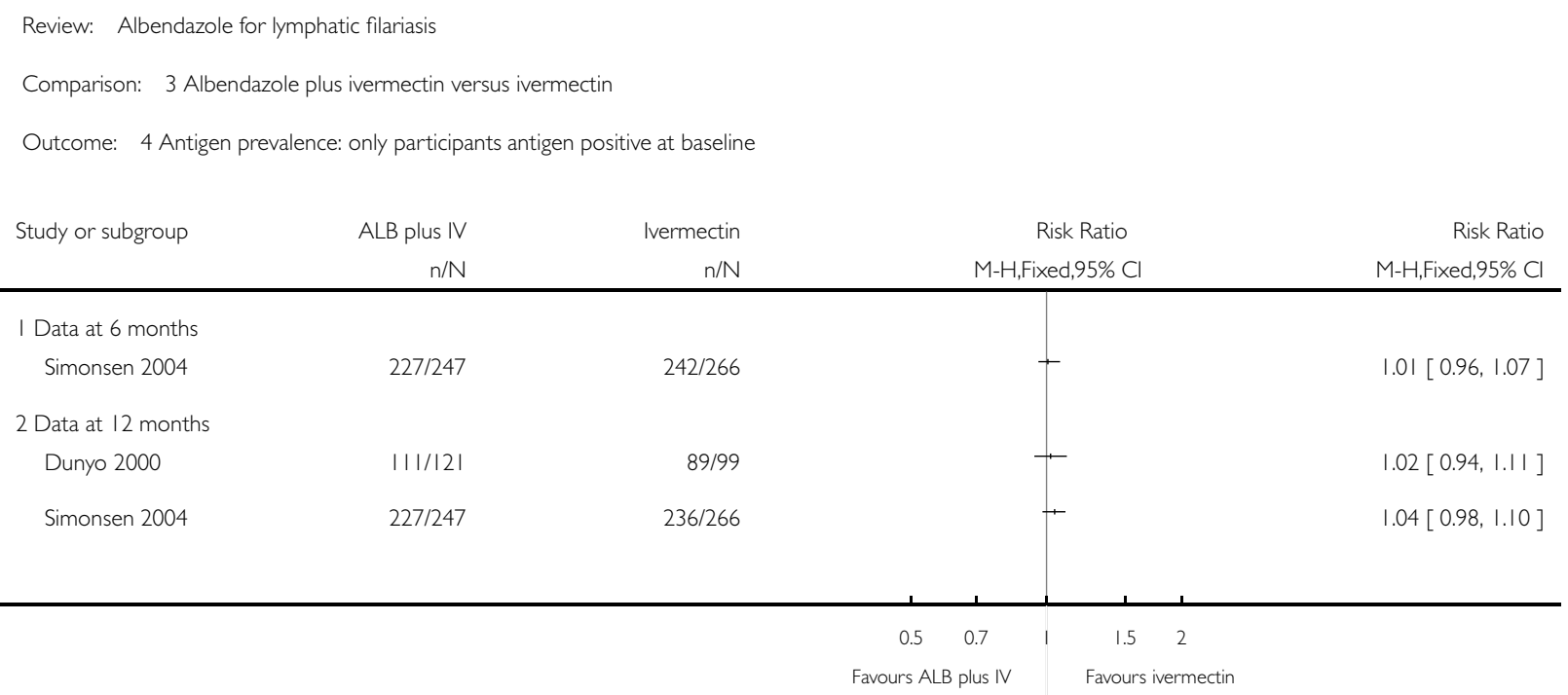

\section{Analysis 3.5. Comparison 3 Albendazole plus ivermectin versus ivermectin, Outcome 5 New clinical disease.}

Review: Albendazole for lymphatic filariasis

Comparison: 3 Albendazole plus ivermectin versus ivermectin

Outcome: 5 New clinical disease

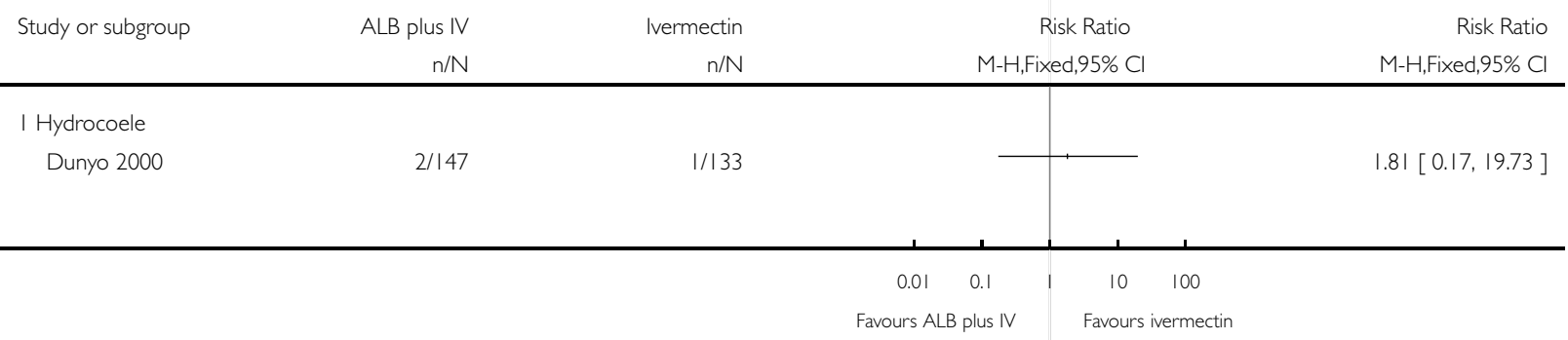


Analysis 3.6. Comparison 3 Albendazole plus ivermectin versus ivermectin, Outcome 6 Pre-existing clinical disease.

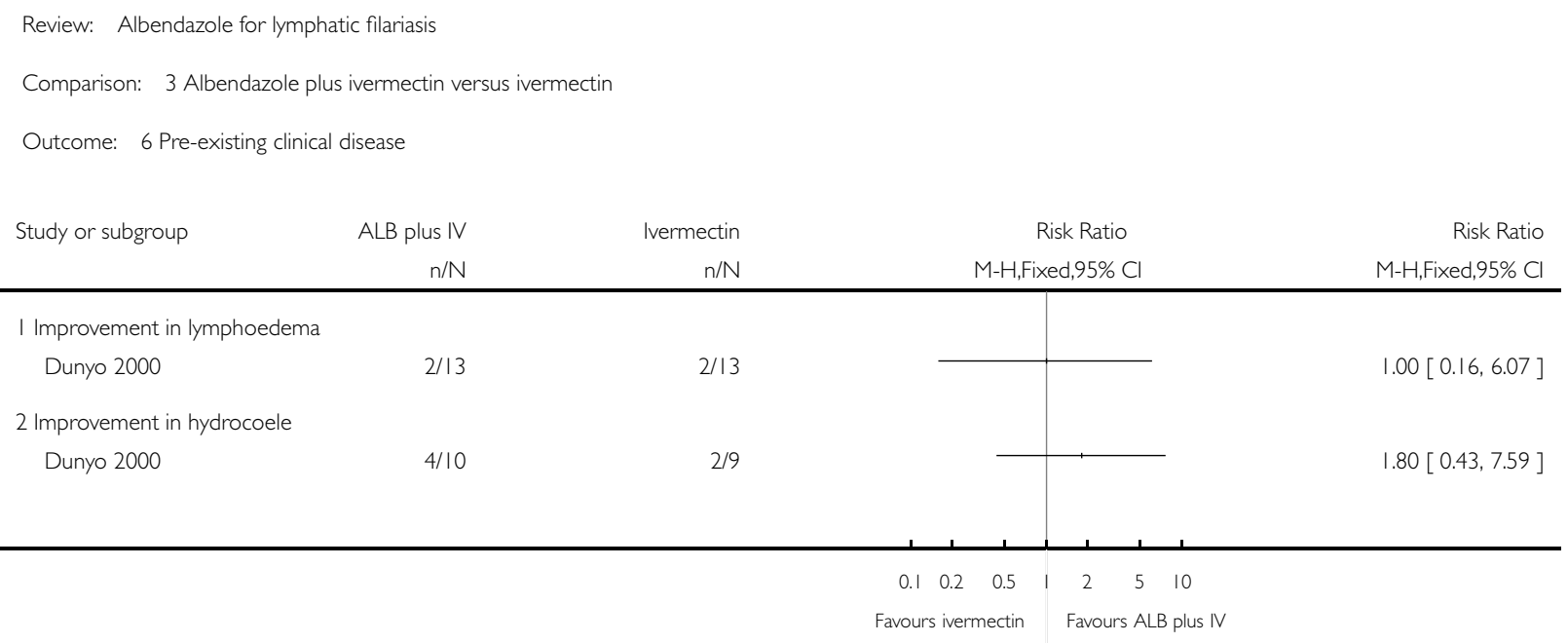

Analysis 3.7. Comparison 3 Albendazole plus ivermectin versus ivermectin, Outcome 7 Adverse events. Review: Albendazole for lymphatic filariasis

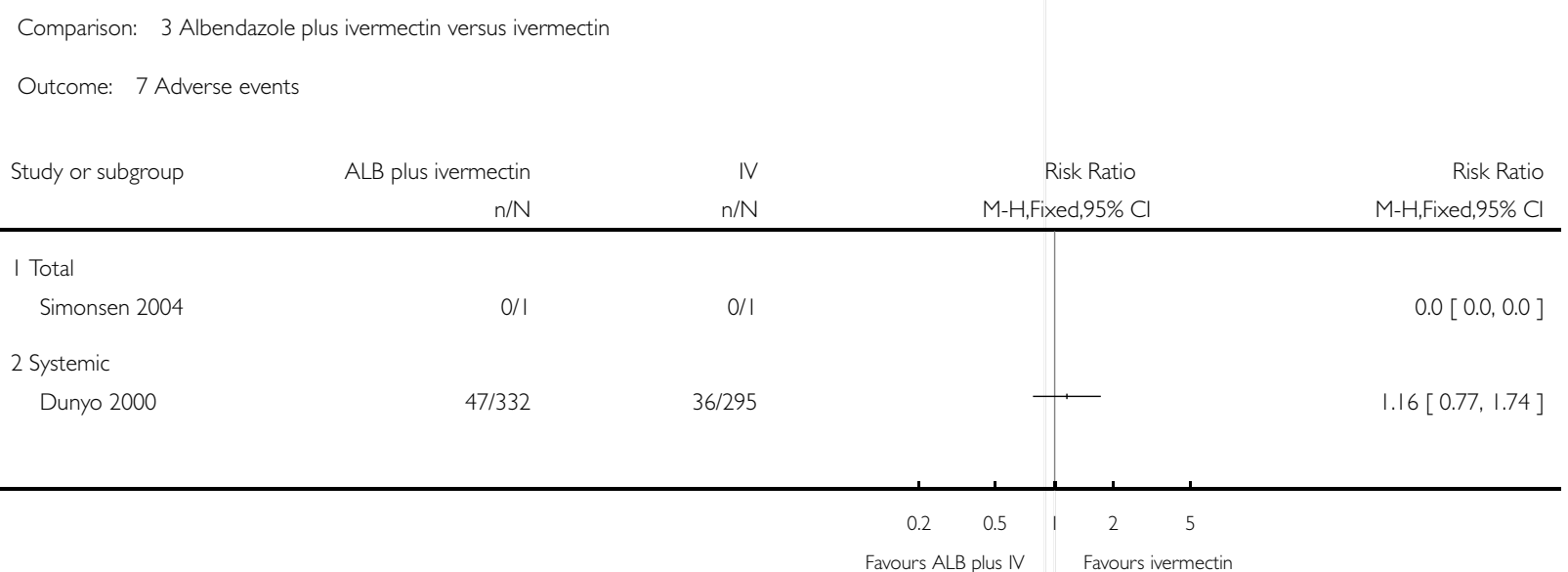




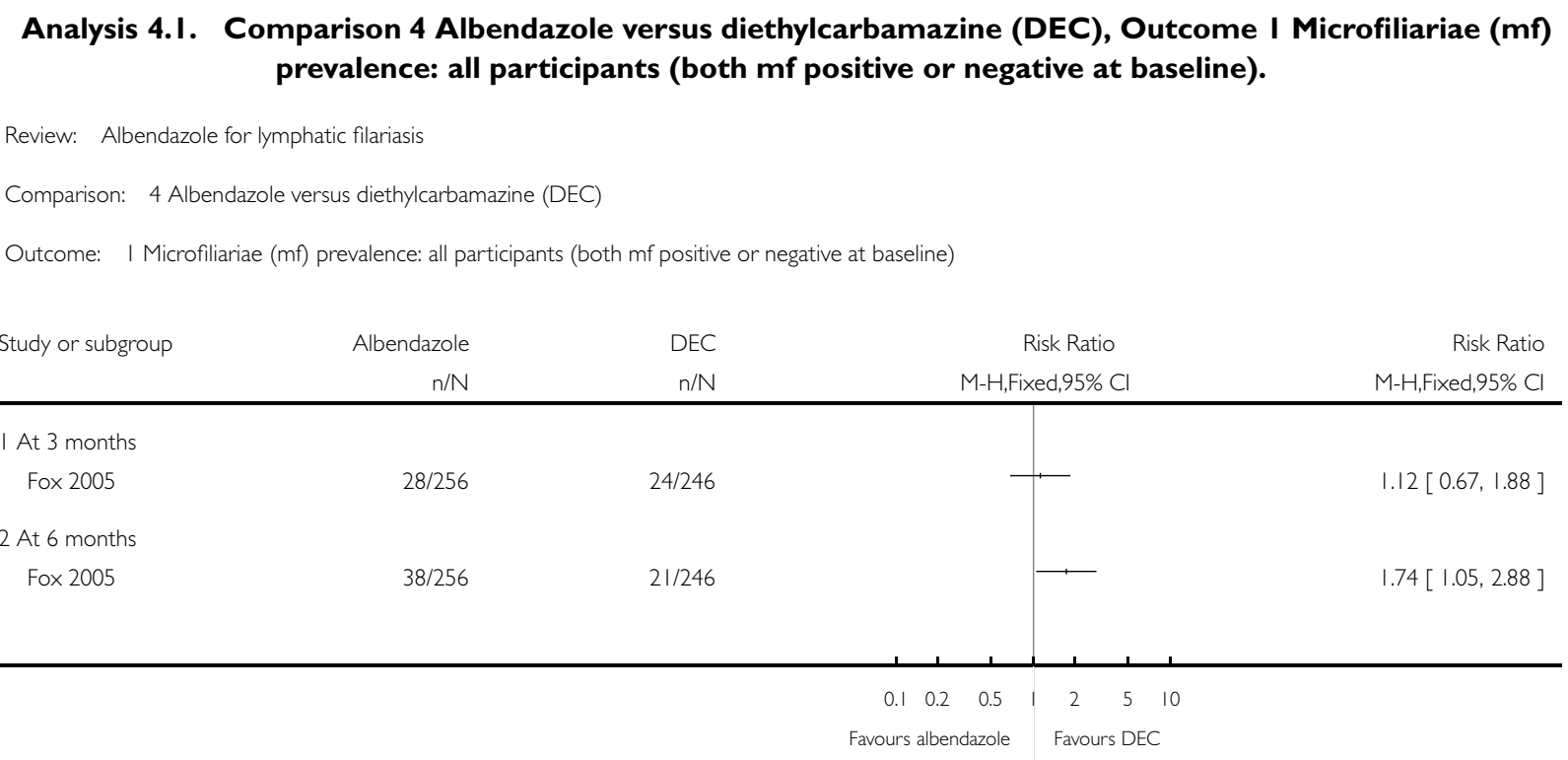

Analysis 4.2. Comparison 4 Albendazole versus diethylcarbamazine (DEC), Outcome 2 Microfilariae (mf) prevalence: only participants $\mathrm{mf}$ positive at baseline.

Review: Albendazole for lymphatic filariasis

Comparison: 4 Albendazole versus diethylcarbamazine (DEC)

Outcome: 2 Microfilariae $(\mathrm{mf})$ prevalence: only participants $\mathrm{mf}$ positive at baseline

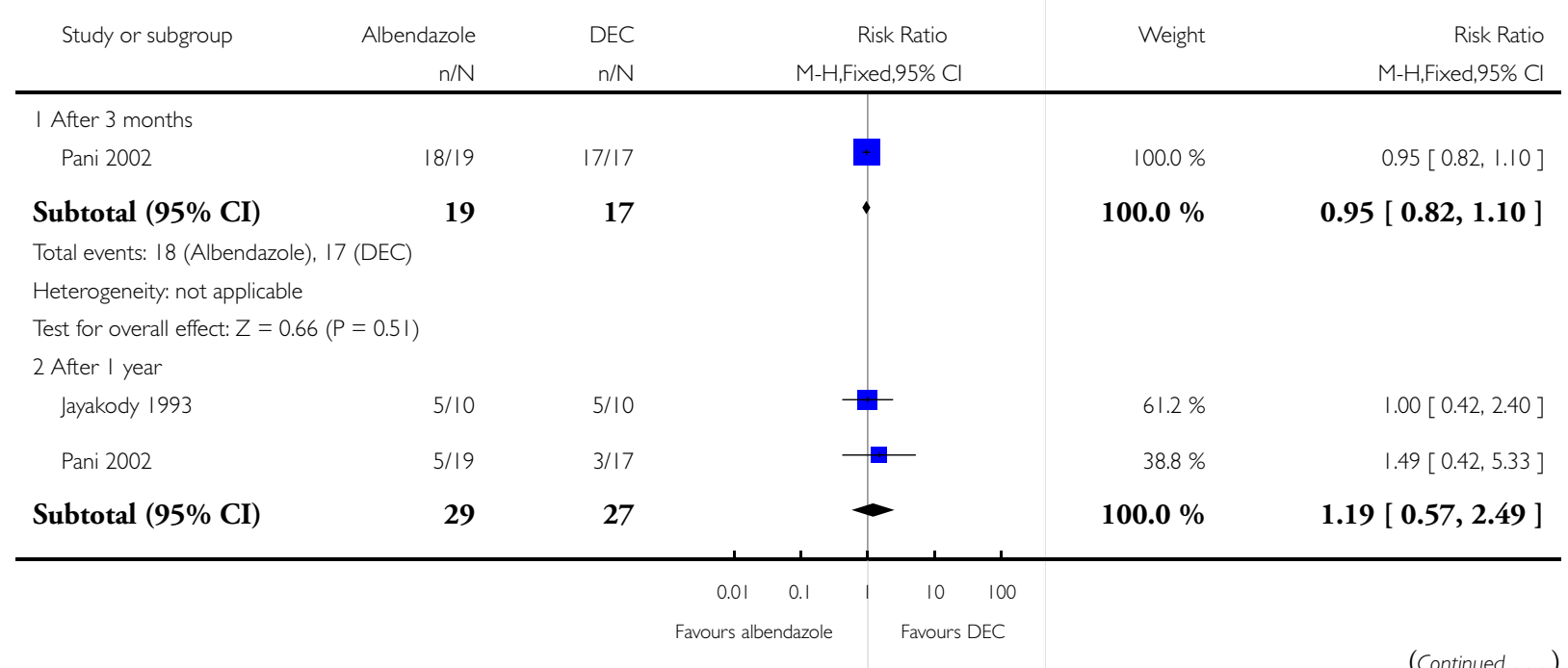




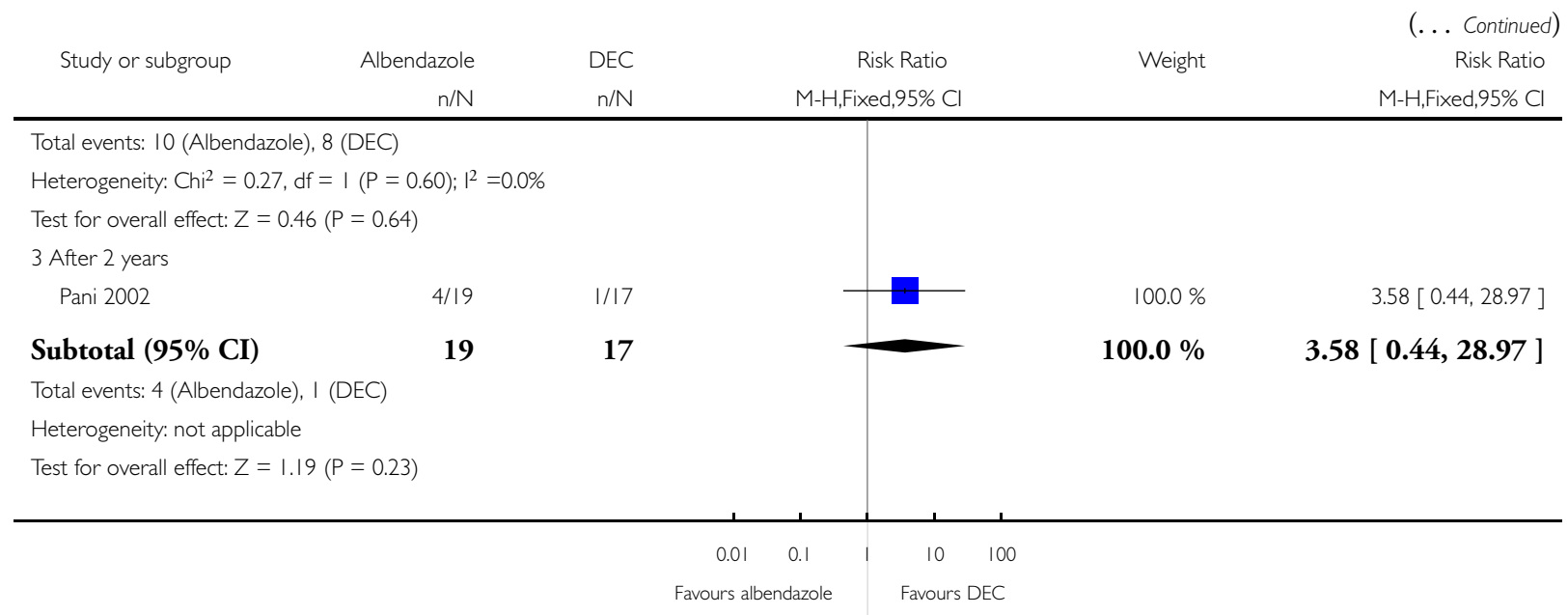

Analysis 4.3. Comparison 4 Albendazole versus diethylcarbamazine (DEC), Outcome 3 Antigen prevalence: all participants (both antigen positive or negative at baseline).

Review: Albendazole for lymphatic filariasis

Comparison: 4 Albendazole versus diethylcarbamazine (DEC)

Outcome: 3 Antigen prevalence: all participants (both antigen positive or negative at baseline)

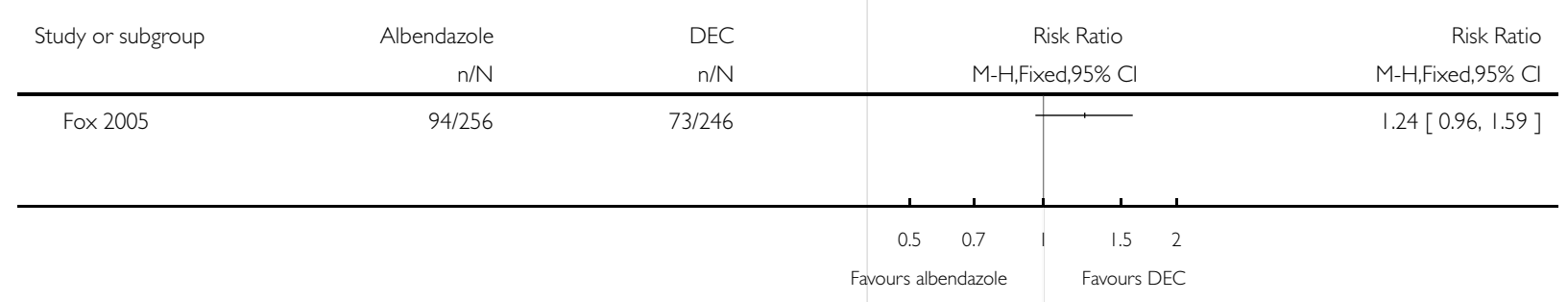


Analysis 4.4. Comparison 4 Albendazole versus diethylcarbamazine (DEC), Outcome 4 Antigen prevalence: only participants antigen positive at baseline.

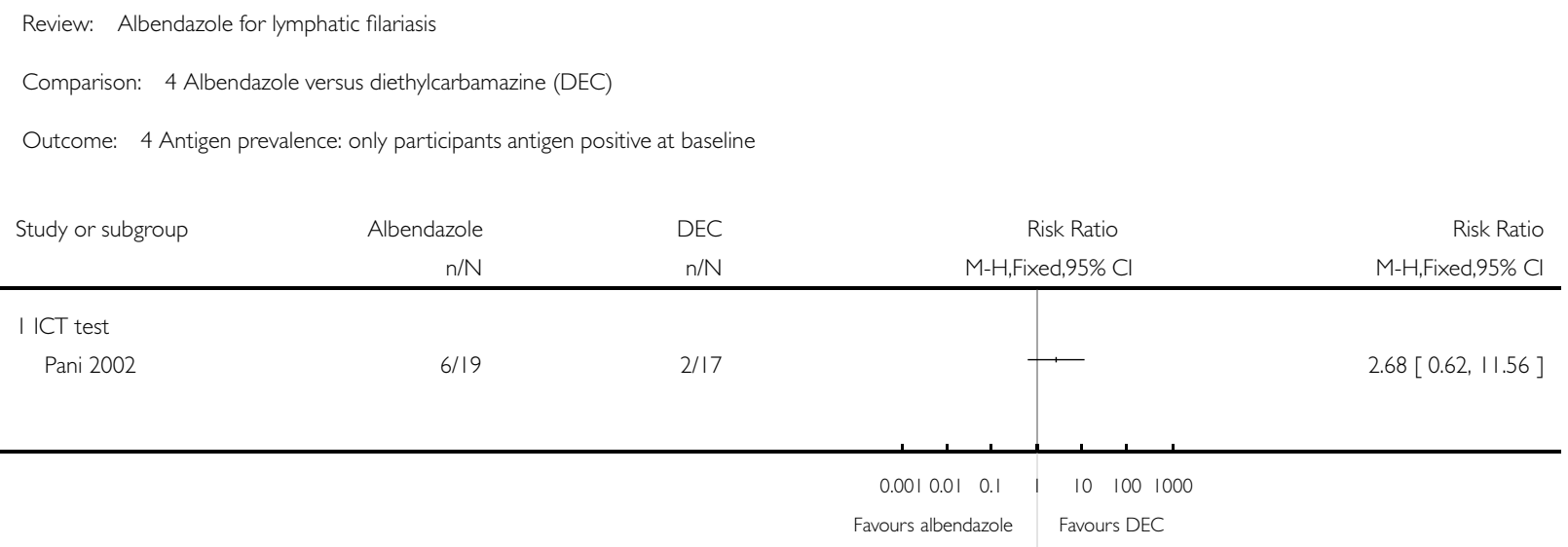

Analysis 4.5. Comparison 4 Albendazole versus diethylcarbamazine (DEC), Outcome 5 Adverse events.

Review: Albendazole for lymphatic filariasis

Comparison: 4 Albendazole versus diethylcarbamazine (DEC)

Outcome: 5 Adverse events

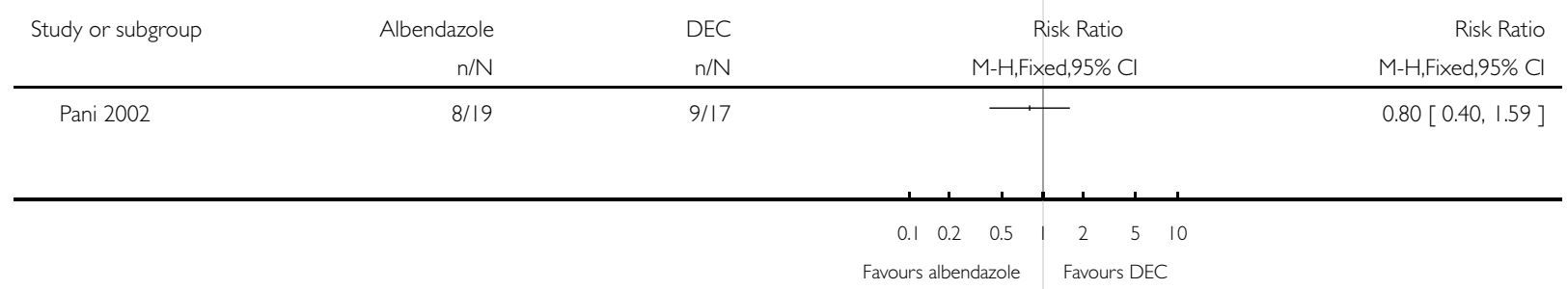


Analysis 4.6. Comparison 4 Albendazole versus diethylcarbamazine (DEC), Outcome 6 Adverse events: scrotal syndrome.

\begin{tabular}{|c|c|c|c|c|}
\hline \multicolumn{5}{|c|}{ Comparison: 4 Albendazole versus diethylcarbamazine (DEC) } \\
\hline \multicolumn{5}{|c|}{ Outcome: 6 Adverse events: scrotal syndrome } \\
\hline \multirow[t]{2}{*}{ Study or subgroup } & Albendazole & DEC & Risk Ratio & Risk Ratio \\
\hline & $\mathrm{n} / \mathrm{N}$ & $\mathrm{n} / \mathrm{N}$ & M-H,Fixed,95\% Cl & M-H,Fixed,95\% Cl \\
\hline Jayakody 1993 & $7 / 15$ & $0 / 12$ & 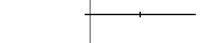 & $12.19[0.77,194.03]$ \\
\hline
\end{tabular}

Analysis 5.I. Comparison 5 Albendazole plus diethylcarbamazine (DEC) versus DEC, Outcome I Microfilariae $(\mathrm{mf})$ prevalence: all participants (both $\mathrm{mf}$ positive or negative at baseline).

Review: Albendazole for lymphatic filariasis

Comparison: 5 Albendazole plus diethylcarbamazine (DEC) versus DEC

Outcome: I Microfilariae ( $\mathrm{mf}$ ) prevalence: all participants (both $\mathrm{mf}$ positive or negative at baseline)

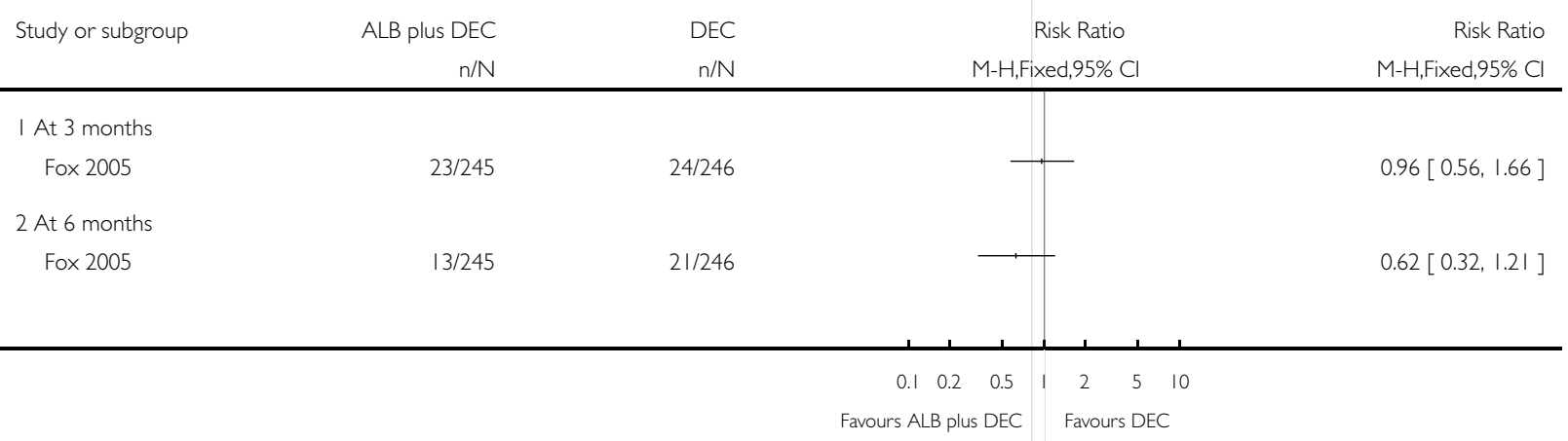


Analysis 5.2. Comparison 5 Albendazole plus diethylcarbamazine (DEC) versus DEC, Outcome 2 Microfilariae $(\mathrm{mf})$ prevalence: only participants $\mathrm{mf}$ positive at baseline.

Review: Albendazole for lymphatic filariasis

Comparison: 5 Albendazole plus diethylcarbamazine (DEC) versus DEC

Outcome: 2 Microfilariae $(\mathrm{mf})$ prevalence: only participants $\mathrm{mf}$ positive at baseline

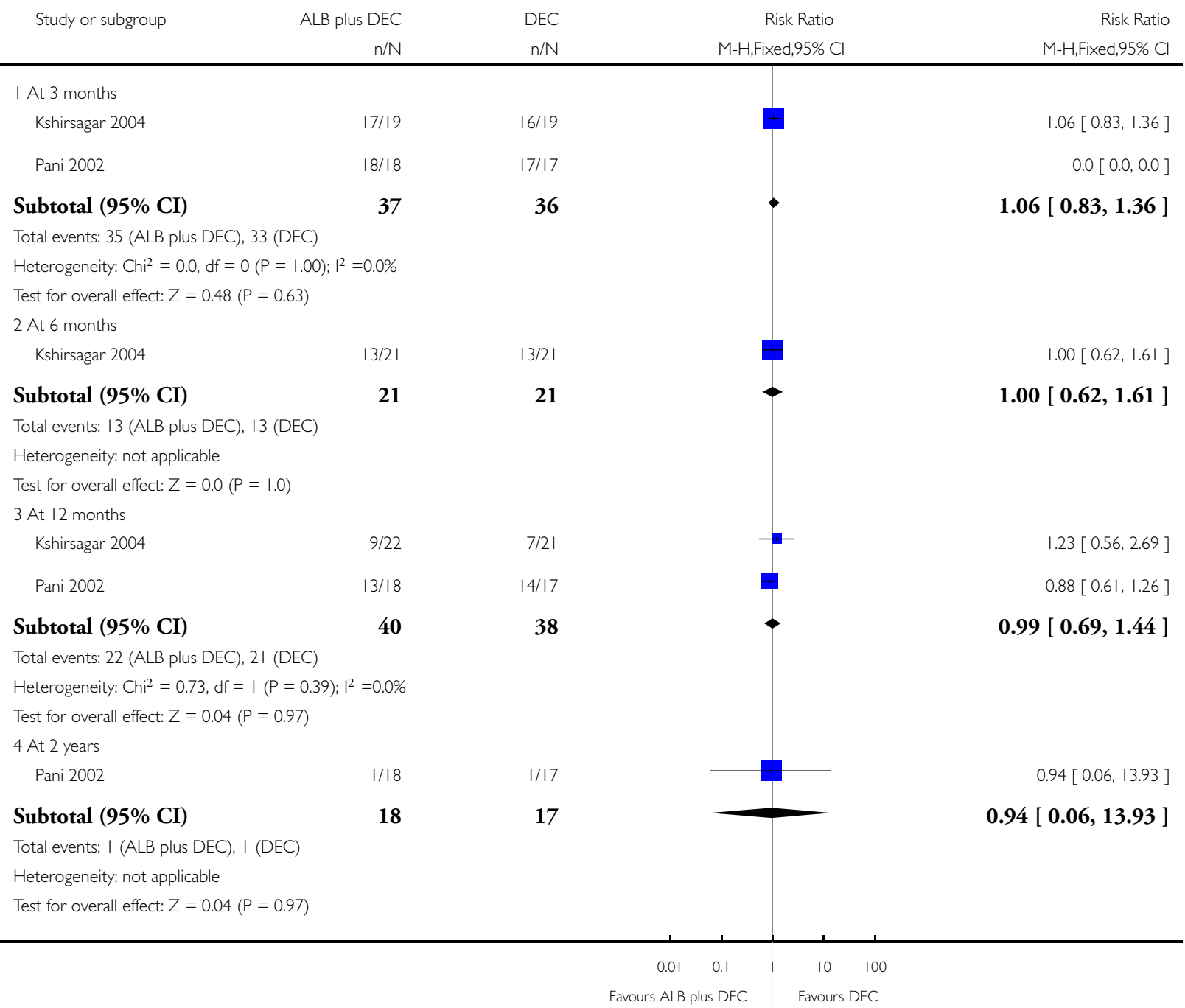




\section{Analysis 5.3. Comparison 5 Albendazole plus diethylcarbamazine (DEC) versus DEC, Outcome 3 Antigen prevalence: all participants (both antigen positive and negative at baseline).}

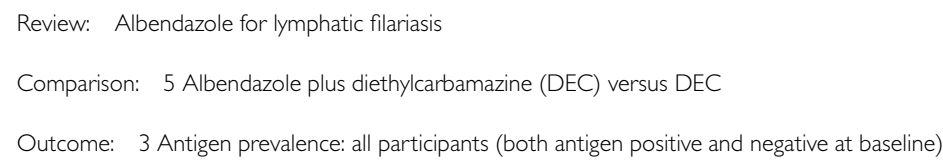

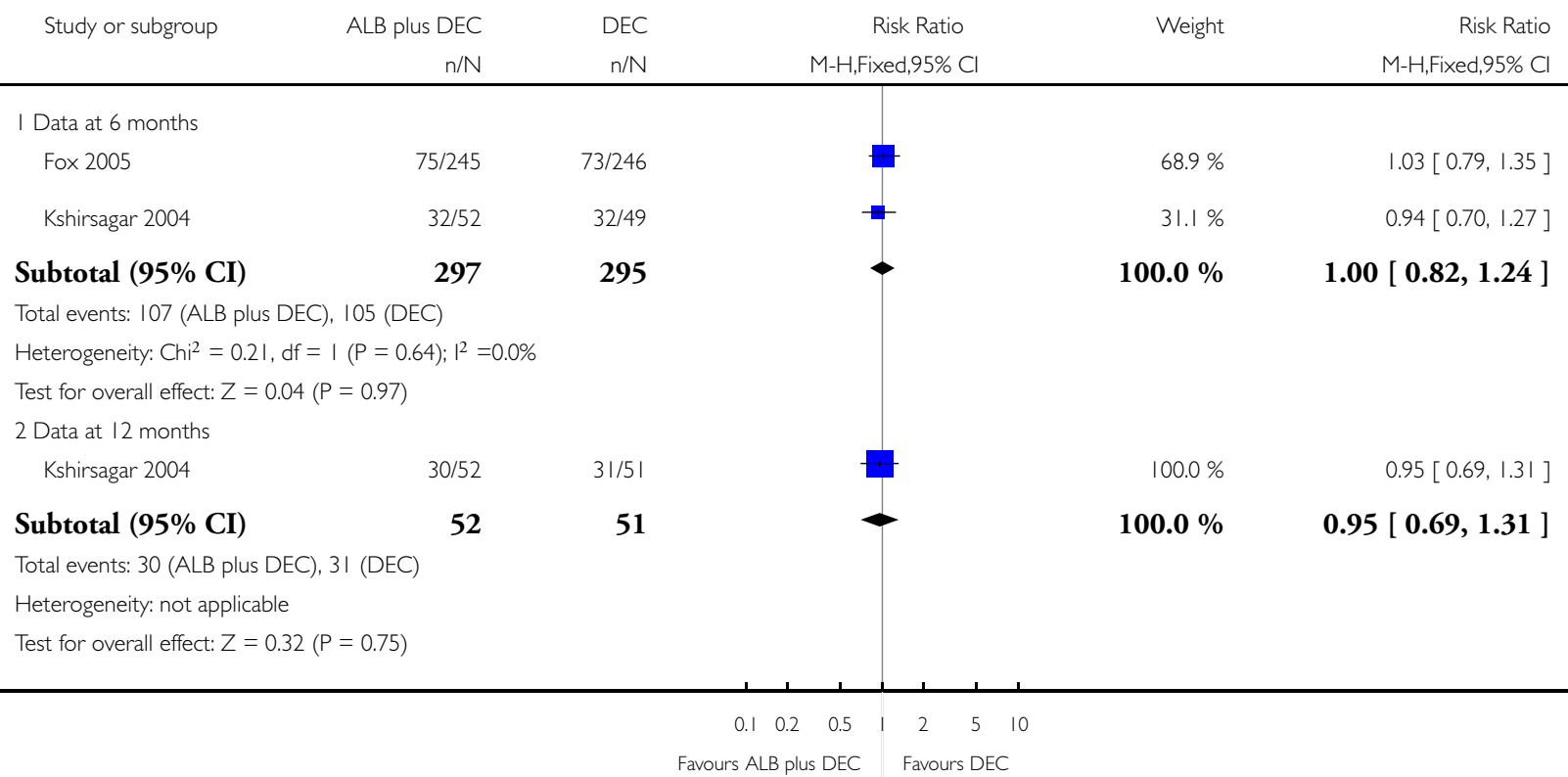

Analysis 5.4. Comparison 5 Albendazole plus diethylcarbamazine (DEC) versus DEC, Outcome 4 Antigen prevalence: only participants antigen positive at baseline.

Review: Albendazole for lymphatic filariasis

Comparison: 5 Albendazole plus diethylcarbamazine (DEC) versus DEC

Outcome: 4 Antigen prevalence: only participants antigen positive at baseline

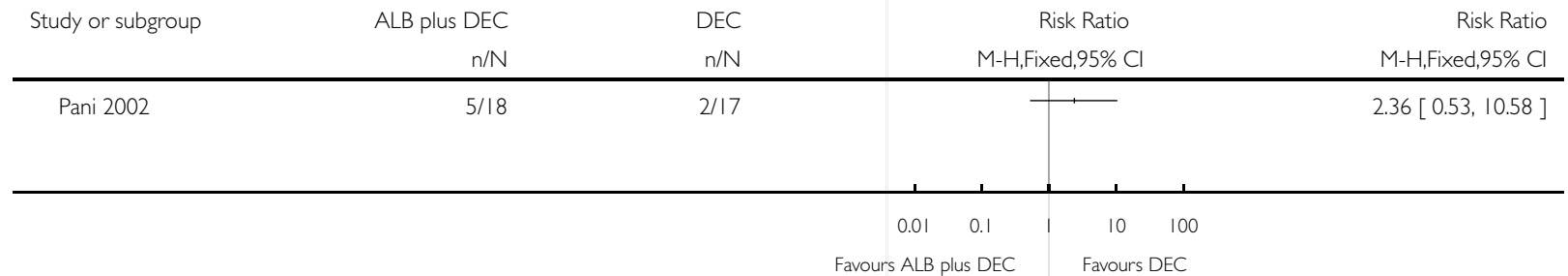


Analysis 5.5. Comparison 5 Albendazole plus diethylcarbamazine (DEC) versus DEC, Outcome 5 Adverse events.

Review: Albendazole for lymphatic filariasis

Comparison: 5 Albendazole plus diethylcarbamazine (DEC) versus DEC

Outcome: 5 Adverse events

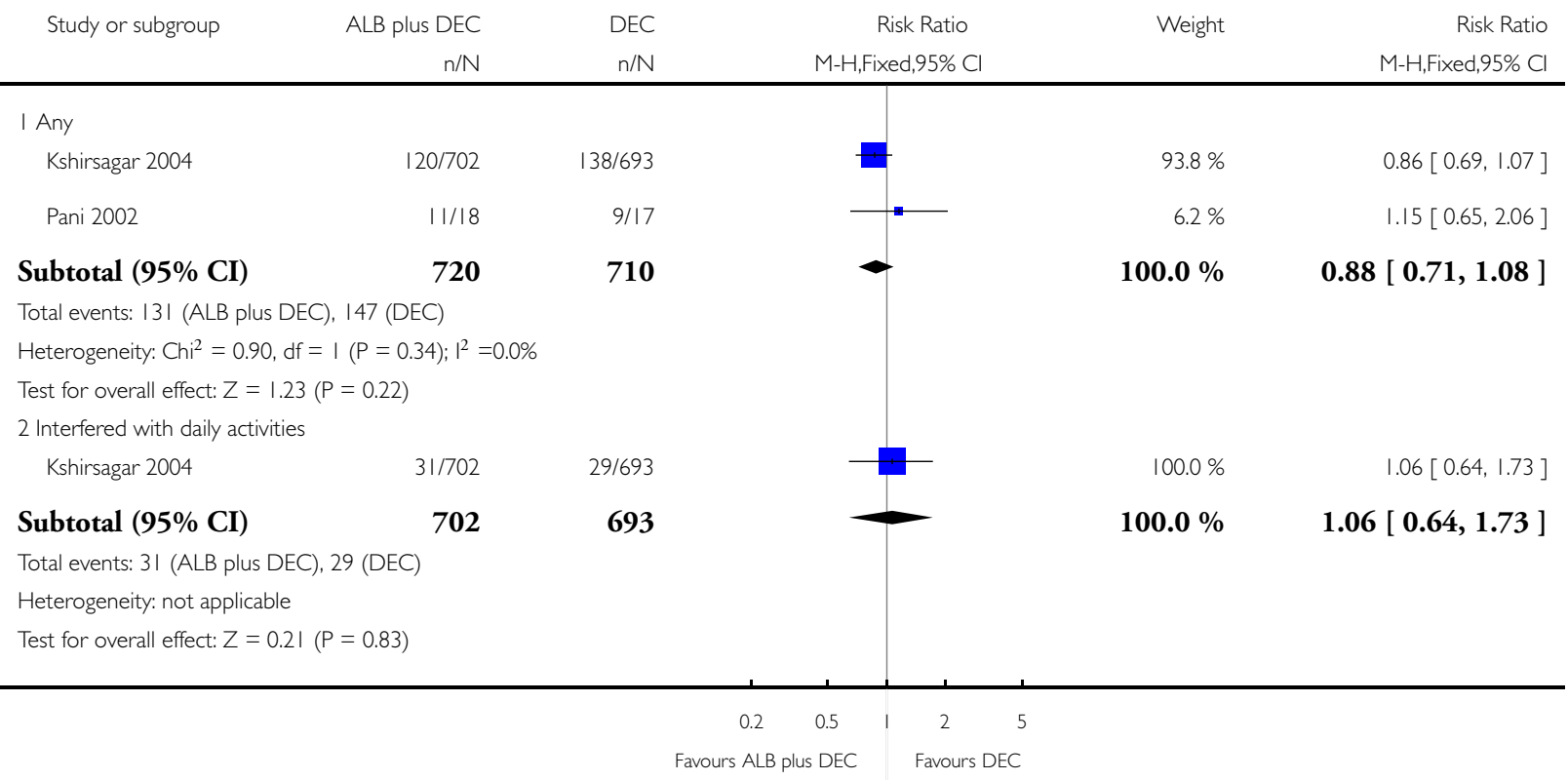

\section{A P P E N D I CES}

Appendix I. Search methods: detailed search strategies

\begin{tabular}{llllll}
\hline Search set & CIDG SR $^{a}$ & CENTRAL & MEDLINE $^{b}$ & EMBASE $^{b}$ & LILACS $^{b}$ \\
\hline 1 & filaria* $^{*}$ & filaria* & FILARIASIS & FILARIASIS & filaria* $^{*}$ \\
\hline 2 & albendazole & elephantiasis & lymphatic filariasis & lymphatic filariasis & elephantiasis \\
\hline 3 & benzimidazole & lymphedema & ELEPHANTIASIS & ELEPHANTIASIS & lymphedema \\
\hline 4 & - & wuchereria & LYMPHEDEMA & lymphedema & wuchereria \\
\hline 5 & - & brugia & Wuchereria bancrofti & Wuchereria bancrofti & brugia
\end{tabular}




\begin{tabular}{|c|c|c|c|c|c|}
\hline 6 & - & 1 or 2 or 3 or 4 or 5 & BRUGIA & BRUGIA & 1 or 2 or 3 or 4 or 5 \\
\hline 7 & - & diethylcarbamazine & 1 or 2 or 3 or 4 or 5 or 6 & 1 or 2 or 3 or 4 or 5 or 6 & diethylcarbamazine \\
\hline 8 & - & ivermectin & FILARICIDES & diethylcarbamazine & ivermectin \\
\hline 9 & - & benzimidazole & diethylcarbamazine & ivermectin & benzimidazole \\
\hline 10 & - & albendazole & ivermectin & benzimidazole & albendazole \\
\hline 11 & - & carbamazine & benzimidazole & albendazole & carbamazine \\
\hline 12 & - & hetrazan & albendazole & carbamazine & hetrazan \\
\hline 13 & - & luxuran & carbamazine & hetrazan & luxuran \\
\hline 14 & - & mectizan & hetrazan & luxuran & mectizan \\
\hline 15 & - & metiazol & luxuran & mectizan & metiazol \\
\hline 16 & - & valbazen & mectizan & metiazol & valbazen \\
\hline 17 & - & 7-16/OR & metiazol & valbazen & $7-16 / \mathrm{OR}$ \\
\hline 18 & - & 6 and 17 & valbazen & $8-17 / \mathrm{OR}$ & 6 and 17 \\
\hline 19 & - & Limit 18 to human & $8-18 / O R$ & 7 and 18 & - \\
\hline 20 & - & - & 7 and 19 & Limit 19 to human & - \\
\hline 21 & - & - & Limit 20 to human & - & - \\
\hline
\end{tabular}

${ }^{a}$ Cochrane Infectious Diseases Group Specialized Register.

${ }^{b}$ Search terms used in combination with the search strategy for retrieving trials developed by The Cochrane Collaboration (Higgins 2005); Upper case: MeSH or EMTREE heading; Lower case: free text term.

\section{Appendix 2. Risk of bias assessment ${ }^{a}$}

\begin{tabular}{lllll}
\hline Trial & $\begin{array}{l}\text { Allocation sequence gen- } \\
\text { eration }\end{array}$ & Allocation concealment & Blinding & Inclusion $^{a}$ \\
\hline Beach 1999 & Adequate & Adequate & Reported as "double blind" & Inadequate \\
\hline Dunyo 2000 & Adequate & Adequate & Double blind & Inadequate \\
\hline Fox 2005 & Adequate & Unclear & Outcome assessors & Inadequate
\end{tabular}


(Continued)

\begin{tabular}{|c|c|c|c|c|}
\hline Jayakody 1993 & Unclear & Unclear & Unclear & Inadequate \\
\hline Kshirsagar 2004 & Unclear & Unclear & Double blind & $\begin{array}{l}\text { Adequate (safety study) } \\
\text { Adequate or inadequate } \\
\text { depending on time point } \\
\text { (efficacy study) }\end{array}$ \\
\hline Pani 2002 & Unclear & Adequate & Double blind & Adequate \\
\hline Simonsen 2004 & Adequate & Adequate & Double blind & Inadequate \\
\hline
\end{tabular}

${ }^{a}$ See the 'Assessment of risk of bias in included studies' for the assessment methods, and the 'Characteristics of included studies' for the methods used in each trial.

${ }^{b}$ Inclusion of all randomized participants in the final analysis.

Appendix 3. Microfilariae prevalence

\begin{tabular}{|c|c|c|c|c|c|c|}
\hline Comparison & Trial & Intervention & No. participants & $\begin{array}{l}\text { +ve post-treat- } \\
\text { ment }\end{array}$ & $\begin{array}{l}\% \text { baseline [re- } \\
\text { ductn] }\end{array}$ & Note \\
\hline \multirow[t]{8}{*}{ ALB vs placebo } & \multirow[t]{2}{*}{ Dunyo 2000} & ALB & 71 & 62 & 87.3 & - \\
\hline & & Placebo & 66 & 62 & 93.9 & - \\
\hline & \multirow[t]{2}{*}{ Beach 1999} & ALB & 29 & 4 months: 22 & 75.9 & $\begin{array}{l}\text { Only partici- } \\
\text { pants mf positive } \\
\text { at baseline }\end{array}$ \\
\hline & & Placebo & 29 & 4 months: 20 & 69.0 & - \\
\hline & \multirow[t]{2}{*}{ Beach 1999} & ALB & 145 & 4 months: 22 & {$[15.4]$} & $\begin{array}{l}\text { Values for partic- } \\
\text { ipants regardless } \\
\text { of } \mathrm{mf} \text { status at } \\
\text { baseline } \\
26(17.9 \%) \mathrm{mf}- \\
\text { positive at base- } \\
\text { line }\end{array}$ \\
\hline & & Placebo & 139 & 4 months: 20 & {$[20.0]$} & $\begin{array}{l}25(18.0 \%) \mathrm{mf}- \\
\text { positive at base- } \\
\text { line }\end{array}$ \\
\hline & \multirow[t]{2}{*}{ Fox 2005} & ALB & 256 & $\begin{array}{l}3 \text { months: } 28 \\
6 \text { months: } 38\end{array}$ & - & - \\
\hline & & Placebo & 243 & $\begin{array}{l}3 \text { months: } 30 \\
6 \text { months: } 36\end{array}$ & - & - \\
\hline
\end{tabular}




\begin{tabular}{|c|c|c|c|c|c|c|}
\hline \multirow[t]{6}{*}{ ALB vs IV } & \multirow[t]{2}{*}{ Dunyo 2000} & ALB & 71 & 6 months: 62 & 87.3 & - \\
\hline & & IV & 70 & 6 months: 52 & 74.3 & - \\
\hline & \multirow[t]{2}{*}{ Beach 1999} & ALB & 145 & 4 months: 22 & {$[15.4]$} & $\begin{array}{l}\text { Values for partic- } \\
\text { ipants regardless } \\
\text { of } \mathrm{mf} \text { status at } \\
\text { baseline } \\
26(17.9 \%) \mathrm{mf}- \\
\text { positive at base- } \\
\text { line }\end{array}$ \\
\hline & & IV & 140 & 4 months: 20 & {$[23.1]$} & $\begin{array}{l}26(17.3 \%) \mathrm{mf}- \\
\text { positive at base- } \\
\text { line }\end{array}$ \\
\hline & \multirow[t]{2}{*}{ Beach 1999} & ALB & 29 & 4 months: 22 & 75.9 & $\begin{array}{l}\text { Only partici- } \\
\text { pants mf positive } \\
\text { at baseline }\end{array}$ \\
\hline & & IV & 28 & 4 months: 17 & 60.7 & - \\
\hline \multirow{6}{*}{$\begin{array}{l}\text { ALB plus IV vs } \\
\text { IV }\end{array}$} & \multirow[t]{2}{*}{ Dunyo 2000} & ALB plus IV & 75 & 6 months: 58 & 77.3 & - \\
\hline & & IV & 70 & 6 months: 52 & 74.3 & - \\
\hline & \multirow[t]{2}{*}{ Beach 1999} & ALB plus IV & 24 & 4 months: 4 & 16.7 & $\begin{array}{l}\text { Only partici- } \\
\text { pants mf positive } \\
\text { at baseline }\end{array}$ \\
\hline & & IV & 28 & 4 months: 17 & 60.7 & - \\
\hline & \multirow[t]{2}{*}{ Simonsen 2004} & ALB plus IV & 105 & $\begin{array}{l}6 \text { months: } 67 \\
12 \text { months: } 75\end{array}$ & $\begin{array}{l}6 \text { months: } 63.8 \\
12 \text { months: } 71.4\end{array}$ & - \\
\hline & & IV & 98 & $\begin{array}{l}6 \text { months: } 85 \\
12 \text { months: } 73\end{array}$ & $\begin{array}{l}6 \text { months: } 86.7 \\
12 \text { months: } 74.5\end{array}$ & - \\
\hline \multirow[t]{2}{*}{ ALB vs DEC } & \multirow[t]{2}{*}{ Pani 2002} & ALB & 19 & $\begin{array}{l}30 \text { d: } 0 \\
90 \text { d: } 18 \\
360 \text { d: } 14 \\
2 \text { yr: } 4\end{array}$ & - & - \\
\hline & & $\mathrm{DEC}$ & 17 & $\begin{array}{l}30 \text { d: } 0 \\
90 \text { d: } 17 \\
360 \text { d: } 14 \\
2 \text { yr: } 1\end{array}$ & - & - \\
\hline
\end{tabular}




\begin{tabular}{|c|c|c|c|c|c|c|}
\hline & \multirow[t]{2}{*}{ Jayakody 1993} & ALB & 16 & $\begin{array}{l}28 \text { d: } 12 / 15 \\
3 \\
\text { months: denom- } \\
\text { inator unclear } \\
6 \text { months: num- } \\
\text { bers unclear } \\
5 \text { to } 19 \text { months: } \\
5 / 10\end{array}$ & - & - \\
\hline & & DEC & 13 & $\begin{array}{l}28 \text { d: } 7 / 12 \\
3 \text { months: } 9 / 12 \\
6 \text { months: } 8 / 12 \\
15 \text { to } 19 \text { months: } \\
5 / 10\end{array}$ & - & - \\
\hline & \multirow[t]{2}{*}{ Fox 2005} & ALB & 256 & $\begin{array}{l}3 \text { months: } 28 \\
6 \text { months: } 38\end{array}$ & - & - \\
\hline & & DEC & 246 & $\begin{array}{l}3 \text { months: } 24 \\
6 \text { months: } 21\end{array}$ & - & - \\
\hline \multirow[t]{6}{*}{$\begin{array}{l}\text { ALB plus DEC } \\
\text { vs DEC }\end{array}$} & \multirow[t]{2}{*}{ Pani 2002} & ALB plus DEC & 18 & $\begin{array}{l}30 \text { d: } 0 \\
90 \text { d: } 18 \\
360 \text { d: } 14 \\
2 \text { yr: } 1\end{array}$ & - & - \\
\hline & & DEC & 17 & $\begin{array}{l}30 \mathrm{~d}: 0 \\
90 \mathrm{~d}: 17 \\
360 \mathrm{~d}: 14 \\
2 \text { yr: } 1\end{array}$ & - & - \\
\hline & \multirow[t]{2}{*}{ Fox 2005} & ALB plus DEC & 245 & $\begin{array}{l}3 \text { months: } 23 \\
6 \text { months: } 13\end{array}$ & - & - \\
\hline & & DEC & 246 & $\begin{array}{l}3 \text { months: } 24 \\
6 \text { months: } 21\end{array}$ & - & - \\
\hline & \multirow[t]{2}{*}{ Kshirsagar 2004} & ALB plus DEC & Varies & $\begin{array}{l}3 \text { months: } 17 / 19 \\
6 \text { months: } 13 / 21 \\
12 \text { months: } 13 / \\
18\end{array}$ & - & - \\
\hline & & DEC & Varies & $\begin{array}{l}3 \text { months: } 16 / 19 \\
6 \text { months: } 13 / 21 \\
12 \text { months: } 14 / \\
17\end{array}$ & - & - \\
\hline
\end{tabular}

ALB: albendazole; DEC: diethylcarbamazine; IV: ivermectin; mf: microfilariae. 


\section{Appendix 4. Antigen prevalence}

\begin{tabular}{|c|c|c|c|c|c|c|c|}
\hline Comparison & Trial & $\begin{array}{l}\text { Outcome } \\
\text { measure }\end{array}$ & Intervention & $\begin{array}{l}\text { No. } \\
\text { participants }\end{array}$ & $\%$ reduction & Pretreatment & $\begin{array}{l}\text { Post- } \\
\text { treatment }\end{array}$ \\
\hline \multirow{4}{*}{$\begin{array}{l}\text { ALB } \\
\text { placebo }\end{array}$} & \multirow[t]{2}{*}{ Dunyo 2000} & \multirow[t]{2}{*}{ CFA positive } & ALB & - & - & 105 & 110 \\
\hline & & & Placebo & - & - & 103 & 102 \\
\hline & \multirow[t]{2}{*}{ Fox 2005} & \multirow[t]{2}{*}{ CFA positive $^{a}$} & ALB & 256 & - & $89(34.8)$ & $94(36.7 \%)$ \\
\hline & & & Placebo & 243 & - & $74(30.5 \%)$ & $81(33.3 \%)$ \\
\hline \multirow[t]{2}{*}{ ALB vs IV } & \multirow[t]{2}{*}{ Dunyo 2000} & \multirow[t]{2}{*}{ CFA positive } & ALB & - & - & 105 & 110 \\
\hline & & & IV & - & - & 99 & 101 \\
\hline \multirow{4}{*}{$\begin{array}{l}\text { ALB plus IV } \\
\text { vs IV }\end{array}$} & \multirow[t]{2}{*}{ Dunyo 2000} & \multirow[t]{2}{*}{ CFA positive } & ALB plus IV & - & - & 121 & 122 \\
\hline & & & IV & - & - & 99 & 101 \\
\hline & \multirow[t]{2}{*}{$\begin{array}{l}\text { Simonsen } \\
2004\end{array}$} & \multirow[t]{2}{*}{ CFA positive* } & ALB plus IV & 247 & $\begin{array}{l}6 \text { months: } \\
91.9 \% \\
12 \text { months: } \\
91.9 \%\end{array}$ & 247 & $\begin{array}{ll}6 & \text { months: } \\
226 & \\
12 & \text { months: } \\
227 & \\
\end{array}$ \\
\hline & & & IV & 266 & $\begin{array}{l}6 \quad \text { months: } \\
91.0 \% \\
12 \text { months: } \\
88.7 \%\end{array}$ & 266 & $\begin{array}{ll}6 & \text { months: } \\
242 & \\
12 & \text { months: } \\
236 & \end{array}$ \\
\hline \multirow[t]{6}{*}{ ALB vs DEC } & \multirow[t]{2}{*}{ Pani 2002} & \multirow{2}{*}{$\begin{array}{l}\text { Antigen posi- } \\
\text { tivity }^{b}\end{array}$} & ALB & 19 & 360 d: 83 & - & - \\
\hline & & & $\mathrm{DEC}$ & 17 & 360 d: 87 & - & - \\
\hline & \multirow[t]{2}{*}{ Pani 2002} & \multirow{2}{*}{$\begin{array}{l}\text { Antigen posi- } \\
\text { tivity }^{c}\end{array}$} & ALB & 19 & 360 d: 83 & - & - \\
\hline & & & $\mathrm{DEC}$ & 17 & 360 d: 80 & - & - \\
\hline & \multirow[t]{2}{*}{ Fox 2005} & \multirow[t]{2}{*}{ CFA positive ${ }^{a}$} & ALB & 256 & - & $89(34.8)$ & $94(36.7 \%)$ \\
\hline & & & DEC & 246 & - & $79(32.1 \%)$ & $73(29.7 \%)$ \\
\hline \multirow[t]{4}{*}{$\begin{array}{l}\text { ALB plus } \\
\text { DEC vs DEC }\end{array}$} & \multirow[t]{2}{*}{ Pani 2002} & \multirow[t]{2}{*}{$\begin{array}{l}\text { Antigen posi- } \\
\text { tivity }^{b}\end{array}$} & $\begin{array}{l}\text { ALB plus } \\
\text { DEC }\end{array}$ & 18 & 360 d: 75 & - & - \\
\hline & & & $\mathrm{DEC}$ & 17 & 360 d: 87 & - & - \\
\hline & \multirow[t]{2}{*}{ Pani 2002} & \multirow[t]{2}{*}{$\begin{array}{l}\text { Antigen posi- } \\
\text { tivity }^{c}\end{array}$} & $\begin{array}{l}\text { ALB plus } \\
\text { DEC }\end{array}$ & 18 & 360 d: 81 & - & - \\
\hline & & & $\mathrm{DEC}$ & 17 & 360 d: 80 & - & - \\
\hline
\end{tabular}


(Continued)

\begin{tabular}{|c|c|c|c|c|c|c|}
\hline \multirow[t]{2}{*}{ Fox 2005} & \multirow[t]{2}{*}{ CFA positive ${ }^{a}$} & $\begin{array}{l}\text { ALB plus } \\
\text { DEC }\end{array}$ & 245 & - & 85 (34.7\%) & $75(30.6 \%)$ \\
\hline & & DEC & 246 & - & 79 (32.1\%) & $73(29.7 \%)$ \\
\hline
\end{tabular}

ALB: albendazole; CFA: circulating filarial antigen; DEC: diethylcarbamazine; IV: ivermectin.

${ }^{a}$ Among children CFA positive at baseline.

${ }^{b}$ Immunochromatographic card test on $50 \mu \mathrm{L}$ serum.

${ }^{c} \mathrm{Og} 4 \mathrm{C} 3$ test kit on $50 \mu \mathrm{L}$ serum.

Appendix 5. Microfilariae density (geometric mean)

\begin{tabular}{|c|c|c|c|c|c|c|c|}
\hline Comparison & Trial & Measure & Intervention & $\begin{array}{l}\text { No. } \\
\text { participants }\end{array}$ & Pretreatment & $\begin{array}{l}\text { Post- } \\
\text { treatment }\end{array}$ & $\%$ reduction \\
\hline \multirow[t]{8}{*}{$\Delta \mathrm{I} \mathrm{R}$} & \multirow[t]{2}{*}{ ח....... } & \multirow[t]{2}{*}{$m f / 1 \cap n \ldots \mathrm{T}$} & תמג & -1 & ممحت & & r-مب \\
\hline & & & Placebo & 66 & 971 & $\begin{array}{l}12 \text { months: } \\
845\end{array}$ & 13.0 \\
\hline & \multirow[t]{2}{*}{ Dunyo 2000} & \multirow{2}{*}{$\begin{array}{l}\text { mf/ } \\
100 \mu \mathrm{L} \text { mea- } \\
\text { sured by AUC } \\
a\end{array}$} & ALB & 42 & 1535 & $\begin{array}{l}12 \text { months: } \\
1233\end{array}$ & 19.7 \\
\hline & & & Placebo & 32 & 2536 & $\begin{array}{l}12 \text { months: } \\
2740\end{array}$ & $\begin{array}{l}108.4(8.4 \% \\
\text { increase })\end{array}$ \\
\hline & \multirow[t]{2}{*}{ Beach $1999^{b}$} & \multirow[t]{2}{*}{$\mathrm{mf} / 20 \mu \mathrm{L}$} & ALB & 28 & 14.1 & 4 months: 5.1 & $28.7\left(63.8^{c}\right)$ \\
\hline & & & Placebo & 29 & 9.3 & 4 months: 5.3 & $17.2\left(43.0^{c}\right)$ \\
\hline & \multirow[t]{2}{*}{ Fox 2005} & \multirow[t]{2}{*}{$\mathrm{mf} / 20 \mu \mathrm{L}$} & ALB & 256 & $\begin{array}{l}12.1(95 \% \mathrm{CI} \\
10.3 \text { to } 14.2)\end{array}$ & $\begin{array}{l}3 \text { months: } 4.7 \\
(95 \% \text { CI } 3.9 \\
\text { to } 5.7) \\
6 \text { months: } 4.4 \\
(95 \% \text { CI } 3.7 \\
\text { to } 5.3 \text { ) }\end{array}$ & $\begin{array}{lr}3 & \text { months: } \\
22.0 & \\
6 & \text { months: } \\
34.7 & \end{array}$ \\
\hline & & & Placebo & 243 & $\begin{array}{l}17.3(95 \% \mathrm{CI} \\
14.5 \text { to } 20.6)\end{array}$ & $\begin{array}{l}3 \text { months: } 8.7 \\
\text { (95\% CI } 7.4 \\
\text { to } 10.2 \text { ) } \\
6 \quad \text { months: } \\
11.2(95 \% \text { CI } \\
9.2 \text { to } 13.7)\end{array}$ & $\begin{array}{l}3 \text { months: } 8.2 \\
6 \text { months: } \\
10.3\end{array}$ \\
\hline \multirow[t]{2}{*}{$\cdots$} & \multirow[t]{2}{*}{ - } & \multirow[t]{2}{*}{-. } & & & & & \\
\hline & & & IV & 70 & 640 & $\begin{array}{l}12 \text { months: } \\
124\end{array}$ & 80.6 \\
\hline
\end{tabular}




\begin{tabular}{|c|c|c|c|c|c|c|c|}
\hline & \multirow[t]{2}{*}{ Dunyo 2000} & \multirow{2}{*}{$\begin{array}{l}\text { mf/ } \\
100 \mu \mathrm{L} \text { mea- }\end{array}$} & \multirow{2}{*}{$\begin{array}{l}\text { ALB } \\
\text { IV }\end{array}$} & 42 & 1535 & $\begin{array}{l}12 \text { months: } \\
1233\end{array}$ & \multirow[t]{2}{*}{19.7} \\
\hline & & & & 33 & 1731 & $\begin{array}{l}12 \text { months: } \\
759\end{array}$ & \\
\hline & \multirow[t]{2}{*}{ Beach 1999} & \multirow[t]{2}{*}{$\mathrm{mf} / 20 \mu \mathrm{L}$} & ALB & 28 & 14.1 & 4 months: 5.1 & $28.7\left(63.8^{c}\right)$ \\
\hline & & & IV & 28 & 15.5 & 4 months: 1.5 & $76.1\left(90.2^{c}\right)$ \\
\hline & & & IV & 70 & 640 & $\begin{array}{l}12 \text { months: } \\
124\end{array}$ & 80.6 \\
\hline & \multirow[t]{2}{*}{ Dunyo 2000} & \multirow{2}{*}{$\begin{array}{l}\mathrm{mf} / \\
100 \mu \mathrm{L} \text { mea- } \\
\text { sured by AUC } \\
a\end{array}$} & ALB plus IV & 40 & 1280 & $\begin{array}{l}12 \text { months: } \\
393\end{array}$ & 30.7 \\
\hline & & & IV & 33 & 1731 & $\begin{array}{ll}12 & \text { months: } \\
759 & \end{array}$ & 56.2 \\
\hline & \multirow[t]{2}{*}{ Beach $1999^{b}$} & \multirow[t]{2}{*}{$\mathrm{mf} / 20 \mu \mathrm{L}$} & ALB plus IV & 24 & 13.7 & 4 months: 0.3 & $98.9\left(97.8^{c}\right)$ \\
\hline & & & IV & 28 & 15.5 & 4 months: 1.5 & $76.1\left(90.2^{c}\right)$ \\
\hline & \multirow[t]{2}{*}{$\begin{array}{l}\text { Simonsen } \\
2004\end{array}$} & \multirow[t]{2}{*}{$\mathrm{mf} / 100 \mu \mathrm{L}$} & ALB plus IV & 105 & 812.6 & $\begin{array}{ll}6 & \text { months: } \\
29.8 & \\
12 & \text { months: } \\
59.4 & \\
\end{array}$ & $\begin{array}{ll}6 & \text { months: } \\
96.3 & \\
12 & \text { months: } \\
83.6 & \\
\end{array}$ \\
\hline & & & IV & 98 & 763.5 & $\begin{array}{lr}6 \quad \text { months: } \\
150.0 \quad 12 \\
\text { months: } \\
124.9\end{array}$ & $\begin{array}{ll}6 & \text { months: } \\
80.4 & \\
12 & \text { months: } \\
83.6 & \end{array}$ \\
\hline \multirow[t]{5}{*}{ ALB vs DEC } & \multirow[t]{2}{*}{ Pani 2002} & \multirow[t]{2}{*}{$\mathrm{mf} / \mathrm{mL}$} & ALB & 19 & $\begin{array}{l}77.6 \text { (range } 22 \\
\text { to } 606 \text { ) }\end{array}$ & - & $\begin{array}{l}3 \mathrm{~d}: 8.7 \\
7 \mathrm{~d}: 14.1 \\
360 \mathrm{~d}: 94.7\end{array}$ \\
\hline & & & DEC & 17 & $\begin{array}{l}81.3 \text { (range } 22 \\
\text { to } 542 \text { ) }\end{array}$ & - & $\begin{array}{l}3 \mathrm{~d}: 26.2 \\
7 \mathrm{~d}: 36.7 \\
360 \mathrm{~d}: 89.6\end{array}$ \\
\hline & \multirow[t]{2}{*}{$\begin{array}{l}\text { Jayakody } \\
1993\end{array}$} & \multirow[t]{2}{*}{$\mathrm{mf} / \mathrm{mL}$} & ALB & 16 & $633+/-150$ & $\begin{array}{l}15 \text { to } 19 \\
\text { months: } 3\end{array}$ & $\begin{array}{l}6 \text { months: } \\
1.91\end{array}$ \\
\hline & & & DEC & 13 & $566+/-120$ & $\begin{array}{l}15 \text { to } 19 \\
\text { months: } 2\end{array}$ & $\begin{array}{ll}6 & \text { months: } \\
0.81 & \\
\end{array}$ \\
\hline & Fox 2005 & $\mathrm{mf} / 20 \mu \mathrm{L}$ & ALB & 256 & $\begin{array}{l}12.1(95 \% \mathrm{CI} \\
10.3 \text { to } 14.2)\end{array}$ & $\begin{array}{l}3 \text { months: } 4.7 \\
\text { ( } 95 \% \text { CI } 3.9 \\
\text { to } 5.7 \text { ) }\end{array}$ & $\begin{array}{ll}3 & \text { months: } \\
22.0 & \\
6 & \text { months: }\end{array}$ \\
\hline
\end{tabular}




\begin{tabular}{|c|c|c|c|c|c|c|c|}
\hline & & & & & & $\begin{array}{l}6 \text { months: } 4.4 \\
(95 \% \text { CI } 3.7 \\
\text { to } 5.3)\end{array}$ & 34.7 \\
\hline & & & DEC & 246 & $\begin{array}{l}12.9(95 \% \mathrm{CI} \\
11.0 \text { to } 15.2)\end{array}$ & $\begin{array}{l}3 \text { months: } 2.9 \\
\text { (95\% CI } 2.5 \\
\text { to } 3.4 \text { ) } \\
6 \text { months: } 2.8 \\
\text { (95\% CI } 2.3 \\
\text { to } 3.4 \text { ) }\end{array}$ & $\begin{array}{lr}3 & \text { months: } \\
31.3 & \\
6 & \text { months: } \\
50.4 & \end{array}$ \\
\hline \multirow[t]{4}{*}{$\begin{array}{l}\text { ALB plus } \\
\text { DEC vs DEC }\end{array}$} & \multirow[t]{2}{*}{ Pani 2002} & \multirow[t]{2}{*}{$\mathrm{mf} / \mathrm{mL}$} & $\begin{array}{l}\text { ALB plus } \\
\text { DEC }\end{array}$ & 18 & $\begin{array}{l}79.4 \text { (range } 22 \\
\text { to } 233 \text { ) }\end{array}$ & - & $\begin{array}{l}3 \mathrm{~d}: 35.7 \\
7 \mathrm{~d}: 45.1 \\
360 \mathrm{~d}: 95.4\end{array}$ \\
\hline & & & DEC & 17 & $\begin{array}{l}81.3 \text { (range } 22 \\
\text { to } 542 \text { ) }\end{array}$ & - & $\begin{array}{l}3 \mathrm{~d}: 26.2 \\
7 \mathrm{~d}: 36.7 \\
360 \mathrm{~d}: 89.6\end{array}$ \\
\hline & \multirow[t]{2}{*}{ Fox 2005} & \multirow[t]{2}{*}{$\mathrm{mf} / 20 \mu \mathrm{L}$} & $\begin{array}{l}\text { ALB plus } \\
\text { DEC }\end{array}$ & 245 & $\begin{array}{l}13.4(95 \% \mathrm{CI} \\
11.4 \text { to } 15.8)\end{array}$ & $\begin{array}{l}3 \text { months: } 2.3 \\
\text { (95\% CI } 2.0 \\
\text { to } 2.7 \text { ) } \\
6 \text { months: } \\
0.76(95 \% \text { CI } \\
0.7 \text { to } 0.9)\end{array}$ & $\begin{array}{lr}3 & \text { months: } \\
37.3 & \\
6 & \text { months: } \\
80.4 & \end{array}$ \\
\hline & & & DEC & 246 & $\begin{array}{l}12.9(95 \% \mathrm{CI} \\
11.0 \text { to } 15.2)\end{array}$ & $\begin{array}{l}3 \text { months: } 2.9 \\
\text { ( } 95 \% \\
\text { CI } 2.5 \text { to } 3.4 \text { ) } \\
6 \text { months: } 2.8 \\
\text { ( } 95 \% \text { CI } 2.3 \\
\text { to } 3.4 \text { ) }\end{array}$ & $\begin{array}{lr}3 & \text { months: } \\
31.3 & \\
6 & \text { months: } \\
50.4 & \end{array}$ \\
\hline
\end{tabular}

ALB: albendazole; AUC: area under the curve; CFA: circulating filarial antigen; CI: confidence interval; DEC: diethylcarbamazine; IV: ivermectin; mf: microfilariae.

${ }^{a}$ Only in those individuals with over $100 \mathrm{mf} / \mu \mathrm{L}$ blood before treatment, and those examined at baseline, and 3, 6, and 12 months. ${ }^{b}$ Only participants positive for $\mathrm{mf}$ at baseline.

${ }^{c}$ Change in group geometric means.

\section{Appendix 6. Antigen density}




\begin{tabular}{|c|c|c|c|c|c|c|c|}
\hline Comparison & Trial & $\begin{array}{l}\text { Outcome } \\
\text { measure }\end{array}$ & Intervention & $\begin{array}{l}\text { No. } \\
\text { participants }\end{array}$ & Pretreatment & $\begin{array}{l}\text { Post- } \\
\text { treatment }\end{array}$ & $\%$ reduction \\
\hline \multirow{4}{*}{$\begin{array}{l}\text { ALB } \\
\text { placebo }\end{array}$} & \multirow[t]{2}{*}{ Dunyo 2000} & \multirow{2}{*}{$\begin{array}{l}\text { CFA unit (ge- } \\
\text { ometric mean } \\
\text { density) }\end{array}$} & ALB & 105 & 1370 & 1139 & 83.1 \\
\hline & & & Placebo & 103 & 1869 & 2757 & $\begin{array}{l}147.5(47.5 \% \\
\text { increase })\end{array}$ \\
\hline & \multirow[t]{2}{*}{ Fox 2005} & \multirow{2}{*}{$\begin{array}{l}\text { CFA unit (ge- } \\
\text { ometric mean } \\
\text { density) }\end{array}$} & ALB & 256 & $\begin{array}{l}2640(95 \% \mathrm{CI} \\
2279 \text { to } 3058)\end{array}$ & $\begin{array}{l}2428(95 \% \mathrm{CI} \\
2071 \text { to } 2847)\end{array}$ & 3.2 \\
\hline & & & Placebo & 243 & $\begin{array}{l}2298(95 \% \text { CI } \\
1951 \text { to } 2706)\end{array}$ & $\begin{array}{l}2479(95 \% \mathrm{CI} \\
2105 \text { to } 2919)\end{array}$ & 1.7 \\
\hline \multirow[t]{2}{*}{ ALB vs IV } & \multirow[t]{2}{*}{ Dunyo 2000} & \multirow{2}{*}{$\begin{array}{l}\text { CFA unit (ge- } \\
\text { ometric mean } \\
\text { density) }\end{array}$} & ALB & 105 & 1370 & 1139 & 83.1 \\
\hline & & & IV & 99 & 1689 & 1187 & 70.3 \\
\hline \multirow{2}{*}{$\begin{array}{l}\text { ALB plus IV } \\
\text { vs IV }\end{array}$} & \multirow[t]{2}{*}{ Dunyo 2000} & \multirow{2}{*}{$\begin{array}{l}\text { CFA unit (ge- } \\
\text { ometric mean } \\
\text { density) }\end{array}$} & ALB plus IV & 121 & 1404 & 834 & 59.4 \\
\hline & & & IV & 99 & 1689 & 1187 & 70.3 \\
\hline \multirow[t]{4}{*}{ ALB vs DEC } & \multirow[t]{2}{*}{ Pani $2002^{a}$} & \multirow{2}{*}{$\begin{array}{l}\text { Og } 4 \mathrm{C} 3 \text { test kit } \\
\text { on } 50 \mu \mathrm{L} \\
\text { serum }\end{array}$} & ALB & 19 & $0.49(\operatorname{sd~} 0.16)$ & $0.08(\mathrm{sd} 0.17)$ & 0.40 \\
\hline & & & DEC & 17 & $0.39(\mathrm{sd} 0.21)$ & $0.07(\mathrm{sd} 0.15)$ & 0.32 \\
\hline & \multirow[t]{2}{*}{ Fox 2005} & \multirow{2}{*}{$\begin{array}{l}\text { CFA unit (ge- } \\
\text { ometric mean } \\
\text { density) }\end{array}$} & ALB & 256 & $\begin{array}{l}2640(95 \% \mathrm{CI} \\
2279 \text { to } 3058)\end{array}$ & $\begin{array}{l}2428(95 \% \mathrm{CI} \\
2071 \text { to } 2847)\end{array}$ & 3.2 \\
\hline & & & DEC & 246 & $\begin{array}{l}2194(95 \% \text { CI } \\
1842 \text { to } 2613)\end{array}$ & $\begin{array}{l}1597(95 \% \mathrm{CI} \\
1375 \text { to } 1855)\end{array}$ & 17.0 \\
\hline \multirow[t]{4}{*}{ ALB plus } & \multirow[t]{2}{*}{ Pani $2002^{a}$} & \multirow[t]{2}{*}{ Og4C3 test kit } & ALB & 18 & $0.47(\mathrm{sd} \mathrm{0.18)}$ & $0.07(\mathrm{sd} 0.15)$ & 0.40 \\
\hline & & & DEC & 17 & $0.39(\mathrm{sd} 0.21)$ & $0.07(\mathrm{sd} 0.15)$ & 0.32 \\
\hline & \multirow[t]{2}{*}{ Fox 2005} & \multirow{2}{*}{$\begin{array}{l}\text { CFA unit (ge- } \\
\text { ometric mean } \\
\text { density) }\end{array}$} & $\begin{array}{l}\text { ALB plus } \\
\text { DEC }\end{array}$ & 245 & $\begin{array}{l}2116(95 \% \text { CI } \\
1798 \text { to } 2490)\end{array}$ & $\begin{array}{l}1350(95 \% \mathrm{CI} \\
1176 \text { to } 1549)\end{array}$ & 26.7 \\
\hline & & & DEC & 246 & $\begin{array}{l}2194(95 \% \text { CI } \\
1842 \text { to } 2613)\end{array}$ & $\begin{array}{l}1597(95 \% \mathrm{CI} \\
1375 \text { to } 1855)\end{array}$ & 17.0 \\
\hline
\end{tabular}

ALB: albendazole; CFA: circulating filarial antigen; CI: confidence interval; DEC: diethylcarbamazine; IV: ivermectin; mf: microfilariae; sd: standard deviation.

${ }^{a}$ Measured at $360 \mathrm{~d}$. 


\section{Appendix 7. Adult worms}

\begin{tabular}{|c|c|c|c|c|c|c|}
\hline Comparison & Trial & $\begin{array}{l}\text { Outcome mea- } \\
\text { sure }\end{array}$ & Intervention & No. participants & Pretreatment & Post-treatment \\
\hline \multirow[t]{2}{*}{ ALB vs DEC } & \multirow[t]{2}{*}{ Pani 2002} & \multirow{2}{*}{$\begin{array}{l}\text { Ultrasonog- } \\
\text { raphy (No. posi- } \\
\text { tive for FDS) }\end{array}$} & ALB & 9 & $4 / 9$ & $\begin{array}{l}1 \text { yr: } 0 / 8 \\
2 \text { yr: } 0 / 7\end{array}$ \\
\hline & & & DEC & 7 & $5 / 7$ & $\begin{array}{l}1 \text { yr: } 0 / 7 \\
2 \text { yr: } 0 / 6\end{array}$ \\
\hline \multirow[t]{4}{*}{$\begin{array}{l}\text { ALB plus DEC } \\
\text { vs DEC }\end{array}$} & \multirow[t]{2}{*}{ Pani 2002} & \multirow{2}{*}{$\begin{array}{l}\text { Ultrasonog- } \\
\text { raphy (No. posi- } \\
\text { tive for FDS) }\end{array}$} & ALB plus DEC & 9 & $5 / 9$ & $\begin{array}{l}1 \mathrm{yr}: 1 / 9 \\
2 \mathrm{yr}: 1 / 9\end{array}$ \\
\hline & & & DEC & 7 & $5 / 7$ & $\begin{array}{l}1 \text { yr: } 0 / 7 \\
2 \text { yr: } 0 / 6\end{array}$ \\
\hline & \multirow[t]{2}{*}{ Kshirsagar 2004} & \multirow[t]{2}{*}{$\begin{array}{l}\text { Ultrasonogra- } \\
\text { phy }\end{array}$} & ALB plus DEC & 51 & $35 / 51(69 \%)$ & $\begin{array}{l}3 \text { months: } 15 / 45 \\
(33 \%) \\
6 \text { months: } 9 / 46 \\
(20 \%) \\
12 \text { months: } 15 / 50 \\
(30 \%)\end{array}$ \\
\hline & & & DEC & 50 & $30 / 50(60 \%)$ & $\begin{array}{l}3 \text { months: } 14 / 44 \\
(32 \%) \\
6 \text { months: } 8 / 45 \\
(18 \%) \\
12 \text { months: } 15 / 49 \\
(31 \%)\end{array}$ \\
\hline
\end{tabular}

ALB: albendazole; DEC: diethylcarbamazine; FDS: filarial dance sign.

\section{Appendix 8. Adverse events}

\begin{tabular}{|c|c|c|c|c|c|c|c|}
\hline Trial & Adverse event & Placebo & ALB & IV & ALB plus IV & DEC & $\begin{array}{l}\text { ALB plus } \\
\text { DEC }\end{array}$ \\
\hline \multirow[t]{4}{*}{ Dunyo 2000} & Tactile fever & $1 / 70(1.4 \%)$ & $3 / 80(3.8 \%)$ & $6 / 66(9.1 \%)$ & $\begin{array}{l}16 / 80 \\
(20.0 \%)\end{array}$ & - & - \\
\hline & Headache & $0 / 70(0 \%)$ & $1 / 80(1.3 \%)$ & $7 / 66(10.6 \%)$ & $\begin{array}{l}14 / 80 \\
(17.5 \%)\end{array}$ & - & - \\
\hline & $\begin{array}{l}\text { Muscle/joint } \\
\text { pain }\end{array}$ & $2 / 70(2.9 \%)$ & $3 / 80(3.8 \%)$ & $9 / 66$ (13.6\%) & $\begin{array}{l}10 / 80 \\
(12.5 \%)\end{array}$ & - & - \\
\hline & Weakness & $1 / 70(1.4 \%)$ & $1 / 80(1.3 \%)$ & $4 / 66(6.1 \%)$ & $7 / 80(8.8 \%)$ & - & - \\
\hline
\end{tabular}




\begin{tabular}{|c|c|c|c|c|c|c|c|}
\hline & $\begin{array}{l}\text { Abdominal } \\
\text { pain }\end{array}$ & $1 / 70(1.4 \%)$ & $1 / 80(1.3 \%)$ & $0 / 66(0 \%)$ & $4 / 80(5 \%)$ & - & - \\
\hline & Diarrhoea & $2 / 70(2.9 \%)$ & $0 / 80(0 \%)$ & $1 / 66(1.5 \%)$ & $2 / 80(2.5 \%)$ & - & - \\
\hline & Itching & $0 / 70(0 \%)$ & $1 / 80(1.3 \%)$ & $2 / 66(3.0 \%)$ & $1 / 80(1.3 \%)$ & - & - \\
\hline & Rash & $1 / 70(1.4 \%)$ & $0 / 80(0 \%)$ & $1 / 66(1.5 \%)$ & $1 / 80(1.3 \%)$ & - & - \\
\hline \multirow{4}{*}{$\begin{array}{l}\text { Beach } 1999 \\
\text { (only partici- } \\
\text { pants mf pos- } \\
\text { itive at base- } \\
\text { line) }\end{array}$} & $\begin{array}{l}\text { Self-reported } \\
\text { fever }\end{array}$ & $7 / 29(24 \%)$ & $5 / 27(19 \%)$ & - & - & - & - \\
\hline & Headache & $12 / 29(41 \%)$ & $6 / 27(22 \%)$ & - & - & - & - \\
\hline & Myalgias & $3 / 29(10 \%)$ & $3 / 27(11 \%)$ & - & - & - & - \\
\hline & Cough & $2 / 29(7 \%)$ & $3 / 27(11 \%)$ & - & - & - & - \\
\hline \multirow[t]{2}{*}{ Pani 2002} & $\begin{array}{l}\text { Any ad- } \\
\text { verse reaction } \\
\text { (mainly fever, } \\
\text { headache, } \\
\text { myalgia) }\end{array}$ & - & $42.1 \%$ & - & - & $52.9 \%$ & $61.1 \%$ \\
\hline & $\begin{array}{l}\text { Mean } \\
\text { intensity score } \\
{ }^{a}(\mathrm{sd})\end{array}$ & - & $1.8(3.0)$ & - & - & $5.6(7.1)$ & $6.7(6.6)$ \\
\hline \multirow[t]{3}{*}{$\begin{array}{l}\text { Jayakody } \\
1993\end{array}$} & $\begin{array}{l}\text { Severe scrotal } \\
\text { syndrome }^{b}\end{array}$ & - & $2 / 15(13 \%)$ & - & - & 0 & - \\
\hline & $\begin{array}{l}\text { Scro- } \\
\text { tal syndrome: } \\
\text { mild, moder- } \\
\text { ate, or severe }\end{array}$ & - & $11 / 15(73 \%)$ & - & - & 0 & - \\
\hline & $\begin{array}{l}\text { Fever, right } \\
\text { hypochon- } \\
\text { drial pain, and } \\
\text { repeated vom- } \\
\text { iting }\end{array}$ & - & $0 / 15$ & - & - & $1 / 13(8 \%)$ & - \\
\hline $\begin{array}{l}\text { Kshirsagar } \\
2004\end{array}$ & $\begin{array}{l}\text { Total num- } \\
\text { ber of partici- } \\
\text { pants with ad- } \\
\text { verse drug re- } \\
\text { actions by day } \\
5\end{array}$ & - & - & - & - & $\begin{array}{l}138 / 693 \\
(20 \%)\end{array}$ & $\begin{array}{l}120 / 702 \\
(17 \%)\end{array}$ \\
\hline
\end{tabular}




\begin{tabular}{|c|c|c|c|c|c|c|c|}
\hline \multicolumn{2}{|c|}{$\begin{array}{l}\text { Total } \\
\text { number of ad- } \\
\text { verse events }\end{array}$} & - & - & - & - & 270 & \multirow[b]{2}{*}{$221(93 \%)$} \\
\hline & $\begin{array}{l}\text { Number of } \\
\text { adverse events } \\
\text { thought likely } \\
\text { to be drug re- } \\
\text { lated }\end{array}$ & - & - & - & - & $256(95 \%)$ & \\
\hline & \multicolumn{7}{|c|}{ OF LIKELY ADVERSE EVENTS: } \\
\hline & $\begin{array}{l}\text { CTC }^{c} \text { Grade } \\
1\end{array}$ & - & - & - & - & 144 & 116 \\
\hline & $\begin{array}{l}\text { CTC }^{c} \text { Grade } \\
2\end{array}$ & - & - & - & - & 65 & 57 \\
\hline & $\begin{array}{l}\text { CTC }^{c} \text { Grade } \\
3\end{array}$ & - & - & - & - & 47 & 48 \\
\hline & $\begin{array}{l}\text { CTC }^{c} \text { Grade } \\
4\end{array}$ & - & - & - & - & 0 & 0 \\
\hline & $\begin{array}{l}\text { No. of partici- } \\
\text { pants where } \\
\text { adverse events } \\
\text { interfered } \\
\text { with daily ac- } \\
\text { tivities }\end{array}$ & - & - & - & - & $\begin{array}{l}29 / 693 \\
(4.2 \%)\end{array}$ & $\begin{array}{l}31 / 702 \\
(4.4 \%)\end{array}$ \\
\hline \multirow[t]{5}{*}{ Fox 2005} & \multicolumn{7}{|c|}{ SPECIFIC SYMPTOMS } \\
\hline & $\begin{array}{l}\text { Self-re- } \\
\text { ported or doc- } \\
\text { umented fever }\end{array}$ & $10 / 43(23 \%)$ & $9 / 46(20 \%)$ & - & - & $16 / 44(36 \%)$ & $\begin{array}{l}25 / 47 \quad(53 \%) \\
(P<0.05 \text { com- } \\
\text { pared with } \\
\text { ALB })\end{array}$ \\
\hline & Headache & $12 / 43(28 \%)$ & $11 / 46(24 \%)$ & - & - & $19 / 44(43 \%)$ & $23 / 49(49 \%)$ \\
\hline & Myalgias & $\begin{array}{l}7 / 43(16 \%)(\mathrm{P} \\
<0.05 \text { com- } \\
\text { pared with } \\
\text { ALB) }\end{array}$ & $1 / 46(2 \%)$ & - & - & $\begin{array}{l}8 / 44(18 \%)(\mathrm{P} \\
<0.05 \text { com- } \\
\text { pared with } \\
\text { ALB })\end{array}$ & $5 / 47(11 \%)$ \\
\hline & Cough & $\begin{array}{l}7 / 43(16 \%)(\mathrm{P} \\
<0.05 \text { com- } \\
\text { pared with } \\
\text { ALB) }\end{array}$ & $1 / 46(2 \%)$ & - & - & $6 / 44(14 \%)$ & $7 / 47(15 \%)$ \\
\hline
\end{tabular}




\begin{tabular}{|c|c|c|c|c|c|c|}
\hline \multicolumn{7}{|c|}{ MEAN TREATMENT IMPACT SCORE (range) ${ }^{d}$} \\
\hline Day 1 & $0.79(0$ to 3$)$ & $0.76(0$ to 3$)$ & - & - & $\begin{array}{l}1.46 \text { (0 to } 3) \\
(P<0.05 \text { com- } \\
\text { pared } \\
\text { with ALB and } \\
\text { placebo) }\end{array}$ & $\begin{array}{l}1.66(0 \text { to } 3) \\
(\mathrm{P}<0.05 \mathrm{com}- \\
\text { pared } \\
\text { with ALB and } \\
\text { placebo })\end{array}$ \\
\hline Day 2 & $0.49(0$ to 2$)$ & $0.26(0$ to 1$)$ & - & - & $\begin{array}{l}0.84 \text { ( } 0 \text { to } 3) \\
(\mathrm{P}<0.05 \text { com- } \\
\text { pared with } \\
\text { ALB })\end{array}$ & $\begin{array}{l}0.66 \text { (0 to } 3) \\
(\mathrm{P}<0.05 \text { com- } \\
\text { pared with } \\
\text { ALB })\end{array}$ \\
\hline Day 3 & $0.16(0$ to 1$)$ & $0.2(0$ to 2$)$ & - & - & $0.36(0$ to 3$)$ & $0.32(0$ to 3$)$ \\
\hline Day 4 & $0.16(0$ to 3$)$ & $0.07(0$ to 1$)$ & - & - & $0.20(0$ to 3$)$ & $0.13(0$ to 1$)$ \\
\hline Day 5 & $0.05(0$ to 1$)$ & $0.02(0$ to 1$)$ & - & - & $0.11(0$ to 2$)$ & $0.06(0$ to 2$)$ \\
\hline Day 6 & $0(0)$ & $0.02(0$ to 1$)$ & - & - & 0.07 (0 to 2$)$ & $0.02(0$ to 1$)$ \\
\hline Day 7 & $0(0)$ & $0(0)$ & - & - & $0(0)$ & $0(0)$ \\
\hline
\end{tabular}

${ }^{a}$ All systemic adverse reactions recorded by assigning score 0 (none), 1 (mild) 2 (moderate) or 3 (severe).

${ }^{b}$ Mild = epididymis felt enlarged and tender, and spermatic cord was tender and nodular, scrotal sac swollen; moderate $=$ swelling of scrotal sac, tender epididymis, swelling, nodularity or cord and some systemic features, eg fever malaise; severe = whole scrotal sac swollen and palpation quite painful, features of acute inflammation eg redness, warmth, pain, swelling, systemic features such as fever, chills, anorexia, nausea.

${ }^{c}$ NCI Common Toxicity Criteria grades; Grade $1=$ mild adverse event, $2=$ moderate adverse event, $3=$ severe adverse event, $4=$ lifethreatening or disabling adverse event, $5=$ death.

${ }^{d} 1$ : symptoms were noticed, but did not interfere with daily activities; 2 : symptoms caused some interference with daily activities; 3 : symptoms prevented usual daily activities.

\section{WHAT'S NEW}

Last assessed as up-to-date: 13 August 2005.

\begin{tabular}{l|l|l}
\hline Date & Event & Description \\
\hline 5 August 2008 & Amended & Converted to new review format with minor editing. \\
\hline
\end{tabular}




\section{H I S T O R Y}

Protocol first published: Issue 4, 2003

Review first published: Issue 1, 2004

\begin{tabular}{|c|c|c|}
\hline Date & Event & Description \\
\hline 14 August 2005 & New search has been performed & $\begin{array}{l}\text { The first review update, published in Issue 4, 2005, includes three new trials, } \\
\text { Fox 2005, Kshirsagar 2004, and Simonsen 2004, and a two-year update of } \\
\text { results from the Pani } 2002 \text { trial. }\end{array}$ \\
\hline
\end{tabular}

\section{CONTRIBUTIONSOFAUTHORS}

Julia Critchley assessed studies for inclusion, extracted data, and is responsible for preparing and updating the review. Paul Garner edited the review, extracted data, and assessed the risk of bias in the trials. David Addiss and Hellen Gelband edited the review. Carrol Gamble edited the review and provided statistical input. Henry Ejere assessed studies for inclusion and extracted data.

\section{DECLARATIONS OF INTEREST}

For the first version of the review (IFRG 2004), Henry Ejere's salary was paid by The Lymphatic Filariasis Support Centre based in the Liverpool School of Tropical Medicine. The Department for International Development, UK and GlaxoSmithKline fund the Lymphatic Filariasis Support Centre. Dr Addiss is an author on one of the trials.

Julia Critchley, Paul Garner, Hellen Gelband, Carrol Gamble: none known.

\section{SOURCES OFSUPPORT}

\section{Internal sources}

- No sources of support supplied

\section{External sources}

- Department for International Development, UK.

\section{DIFFERENCES BETWEEN PROTOCOLANDREVIEW}

The first version of the review (IFRG 2004), published in Issue 1, 2004, deviated from the published protocol: Julia Critchley was invited to join the review team; the objectives were reworded; and the subgroups were removed from the review methods because they were no longer appropriate. 


\section{N D EX TERMS}

\section{Medical Subject Headings (MeSH)}

Albendazole [*therapeutic use]; Diethylcarbamazine [therapeutic use]; Drug Therapy, Combination; Elephantiasis, Filarial [*drug therapy]; Filaricides [*therapeutic use]; Ivermectin [therapeutic use]; Randomized Controlled Trials as Topic

\section{MeSH check words}

Humans 